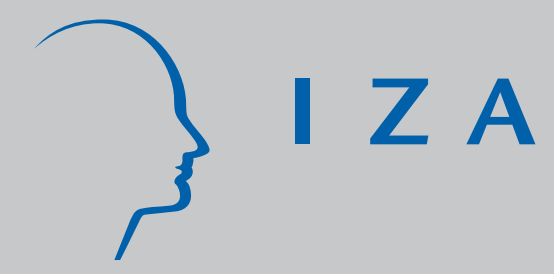

IZA DP No. 3181

\title{
Earnings Over the Lifecycle:
}

The Mincer Earnings Function and Its Applications

Solomon W. Polachek

November 2007 


\title{
Earnings Over the Lifecycle: The Mincer Earnings Function and Its Applications
}

\author{
Solomon W. Polachek \\ State University of New York at Binghamton \\ and IZA
}

Discussion Paper No. 3181

November 2007

\author{
IZA \\ P.O. Box 7240 \\ 53072 Bonn \\ Germany \\ Phone: +49-228-3894-0 \\ Fax: +49-228-3894-180 \\ E-mail: iza@iza.org
}

Any opinions expressed here are those of the author(s) and not those of the institute. Research disseminated by IZA may include views on policy, but the institute itself takes no institutional policy positions.

The Institute for the Study of Labor (IZA) in Bonn is a local and virtual international research center and a place of communication between science, politics and business. IZA is an independent nonprofit company supported by Deutsche Post World Net. The center is associated with the University of Bonn and offers a stimulating research environment through its research networks, research support, and visitors and doctoral programs. IZA engages in (i) original and internationally competitive research in all fields of labor economics, (ii) development of policy concepts, and (iii) dissemination of research results and concepts to the interested public.

IZA Discussion Papers often represent preliminary work and are circulated to encourage discussion. Citation of such a paper should account for its provisional character. A revised version may be available directly from the author. 
IZA Discussion Paper No. 3181

November 2007

\section{ABSTRACT \\ Earnings Over the Lifecycle: The Mincer Earnings Function and Its Applications ${ }^{*}$}

In 1958 Jacob Mincer pioneered an important approach to understand how earnings are distributed across the population. In the years since Mincer's seminal work, he as well as his students and colleagues extended the original human capital model, reaching important conclusions about a whole array of observations pertaining to human well-being. This line of research explained why education enhances earnings; why earnings rise at a diminishing rate throughout one's life; why earnings growth is smaller for those anticipating intermittent labor force participation; why males earn more than females; why whites earn more than blacks; why occupational distributions differ by gender; why geographic and job mobility predominate among the young; and why numerous other labor market phenomena occur. This paper surveys the answers to these and other questions based on research emanating from Mincer's original earnings function specification.

JEL Classification: J1, J3, J7

Keywords: Mincer, earnings, earnings function, gender, discrimination

Corresponding author:

Solomon W. Polachek

Department of Economics

State University of New York at Binghamton

Binghamton, New York 13902-6000

USA

E-mail: Polachek@binghamton.edu

* This paper draws on and extends material from Polachek (1995) and Polachek (2003). I thank Thomas Kniesner and James Ziliak for insightful comments on an earlier draft. 


\section{Lifecycle Earnings:}

\section{The Basis and Application of the Mincer Earnings Function}

\section{Introduction: Why Study Earnings Functions?}

Over the last half century labor economics has undergone a major transformation. Rather than view labor as an amalgam of homogeneous workers in an aggregate economy-wide production function, modern labor economics considers labor as a conglomeration of heterogeneous human beings each differing in on-the-job productivity. Nowadays labor economists emphasize how economies enhance worker productivity employee-by-employee through motivating workers to put out effort and to invest in human capital. As a result labor economists concentrate on the earnings distribution across workers rather than the functional distribution of income between labor and capital. How this shift in emphasis came about is an interesting story. It begins with Wassily Leontief, Theodore Schultz and D. Gale Johnson, but continues with Jacob Mincer and later extends to today’s research on effort enhancing contracts.

Leontief, in 1946, found U.S. exports to be labor rather than capital intensive. This was surprising because U.S. wages were relatively high compared to wages in other countries. Based on the theory of comparative advantage, the U.S. should have exported capital intensive commodities, given her relatively high wages. Yet, as just mentioned, using an input-output table for 1939, Leontief (1946) found U.S. exports to be labor rather than capital intensive.

About 15 years later, Schultz (1961) found prevailing economic models failed to fully account for U.S. growth. Between 1919 and 1957 per annum U.S. output rose 3.1\%, while labor and capital increased a mere 1\% (1961: 50). According to Schultz, output rose far more quickly than one would expect given the secular increases in capital and labor. Similarly in Britain and other countries, changes in physical capital and labor also explained only a fraction of the growth of national income. 
At the same time the proportion of National Income going to labor rose. According to Johnson (1954), in the decade 1900-1910, labor's share was about $69.4 \%$ of national income. Four decades later, in 1940-1949, it was 75.2\%. Based on the National Income and Products Account's compensation data, Krueger (1999) estimated labor's share to be about $77 \%$ in 1998.

When these three findings emerged, the theory of comparative advantage along with the prevailing growth theory models relied on the standard neoclassical production function framework. One limitation of this framework was the assumption of input homogeneity. Homogeneity implies each unit of capital is identical to each other, as is each unit of labor. Because few countries achieved sustained levels of economic growth without having invested substantially in education, researchers began to question whether input quality, particularly for labor, really was constant. Since education and training reflect labor quality, a new line of research, namely human capital theory developed to study how society invests to enhance worker quality, and hence worker productivity. As such Leontief's paradoxical finding that U.S. exports are labor intensive could be solved by realizing that U.S. workers had a relatively high skill embodiment. Similarly unmeasured worker human capital could explain Schultz's observation regarding U.S. growth, and at the same time Johnson's finding that labor's share of national income increased.

Although these developments took place in the 1950s and 1960s, human capital theory actually had its roots at least as far back as Sir William Petty who considered labor to be "the father of wealth" (Kiker, 1971:62). Petty capitalized the wage bill (which he got by deducting property income from national income) to obtain an estimate of human wealth (Hull, 1899, I, 108). Slightly later, the Spanish economist Gasper Melchor de Jovellanos (1744-1811), another very early human capital pioneer (Street, 1988), dealt with the capitalized value of labor and applied his human capital ideas to redirect financing so that Spain could use education to solve its economic problems. Other early economists who considered human capital include Adam Smith, Jean Baptiste Say, 
Nassau William Senior, Friedrich List, Johann Heinrich von Thünen, Ernst Engell, Léon Walras, Irving Fisher (Kiker, p. 51) and Karl Marx (J. R. Walsh (1935). Indeed according to Kiker "human capital was somewhat prominent in economic thinking until Marshall discarded the notion as 'unrealistic' (ibid., 51) ... since human beings are not marketable (ibid., 60)."

These economists were primarily concerned with the capitalized value of labor particularly as it applied to measuring national wealth and the resulting changes in national wealth caused by war (Giffen, 1980; Guyot, 1914; Boag, 1916) or immigration (Kapp, 1870). Not considered were life cycle aspects of an individual's investment decisions. However, in 1935 John Walsh produced tables essentially containing ageearnings profiles for select occupations (law, engineering and medicine) and in the process computed net present values (that is, benefits minus costs) for each. Similarly Milton Friedman and Simon Kuznets (1945) go one step further by comparing present values for U.S professional practitioners to determine "whether the assumptions of perfect competition do describe the world we live in, or whether the analysis of income differences should be based on the theory of non-competing groups” (Barna, 1947: 64).

With an interest primarily to explain a country's growth, initial research considered aggregate measures of human capital. Perhaps this is why Schultz developed exhaustive measures of U.S. human capital stock (Schultz, 1961). From these he tried to quantify the portion of GNP growth unexplained by conventional models. While macroeconomic growth considerations can explain motives for public human capital investment, other patterns, such as repeated evidence that the most educated workers have the highest earnings led researchers to explore reasons why individuals devote their own resources to educational investments. Clearly if education enhances personal earnings then private spending on education pays. Understanding such investments in education resulted in studies deriving methods to estimate private (Becker, 1964) and social rates of return (Psacharopoulos, 1985). 
Although Arthur Pigou (1928: 29) in his statement "there is such a thing as human capital [emphasis mine] as well as investment in material capital” was probably the first to use the term human capital when describing ambiguities between consumption and investment, Mincer (1958) was the first to employ the term prominently in his pioneering work to model earnings distribution using the mathematical tools of neoclassical capital theory. By developing a very parsimonious model first utilizing only schooling (and later age and annual weeks worked), he was able to account for about 60 percent of the variation in U.S. annual earnings for adult white men. His resulting "earnings functions" have been applied in over 100 countries with the same resounding success achieved with U.S. data. Invariably, according to computations based on his methodology, schooling rates of return are in the 5 to $15 \%$ range, exactly the same range as high-grade commercial investments. Similarly all cross-sectional earnings profiles proved concave, just as he predicted.

Understanding individual earnings gets at the very core of social science because it answers questions regarding the very foundations behind human well-being. Indeed comprehending the determinants of earnings helps policy makers develop tactics to promote wealth, to help ease poverty and eventually to put countries on a path to increased growth and prosperity. Human capital theory shows that neither luck nor decree lessen poverty, but instead concerted individual investments in human capital raise earnings and ease deprivation. Even low-ability workers can benefit from training. These insights led to viable policies increasing overall wealth. As many have shown (for example, Barro and Sala-i-Martin, 1999), human capital theory has strong implications for economic growth.

Before Mincer's 1958 article, the predominant theories of earnings distribution relied mostly on luck to determine who succeeded financially. Such theories offered no economic rationale into the earnings distribution process. However, by adopting notions of Adam Smith's theory of compensating differentials coupled with Friedman's notions of "choices among alternative [work options] differing in the probability distribution of the income they promise" [Mincer, 1974: 6], Mincer was able to devise an entirely new 
theory. His innovation was to realize that an individual's choices produced income streams easily evaluated using capital theory. Treating schooling and occupation as investment opportunities, he ingeniously modeled the outcome of a person's investment choices. By assuming individuals invest up to the point where investment costs just equal the present value of schooling gains, he obtained a simple and tractable econometric specification leading to the now famous log-linear earnings function. Not only did this formulation provide a measure of private rates of return to schooling, but it easily generalized to get at post-school on-the-job training, as well. This work showed that a worker's wages consistently rise over the life cycle at a decreasing rate, yielding a concave earnings profile for most individuals. Subsequent work by Ben-Porath motivates some of the technical assumptions Mincer makes to estimate this concavity. Human capital theory also explains gender, race, and ethnic differences in earnings, geographic and job mobility, occupational choice as well as worker turnover, unemployment, and other labor market phenomena.

At present, a number of survey articles have been written on the Mincer earnings function. Perhaps four of the recently most popular are Card (1995, 1999); Heckman, Lochner and Todd (2003); and Lemieux (2006). Card concentrates on econometric issues with regard to identifying the causal relationship between schooling and earnings. Heckman, Todd and Lochner concentrate on empirical support using past and current data and on how to best incorporate future earnings uncertainty. Lemieux concentrates on how well the most common version of the Mincer earnings function fits current data. In short, these three surveys focus heavily on econometric issues. This survey differs from each of these. Whereas some econometric issues are covered, this survey focuses more on the underlying economics behind the Mincer earnings function, as well as its robustness and its relevance to policy applications. Topics include verifying the consistently observed cross-sectional concavity and corroborating implications regarding earnings distribution particularly at the “overtaking” age, across many countries and demographic groups. Among the policy relevant applications are how to use Mincer's theories to estimate discrimination, particularly race and gender differences in both earnings and occupational distributions. In addition, the survey shows how with a simple modification 
the earnings function can be adapted to measure incomplete information in labor markets, an extension which is important in measuring just how competitive particular labor markets really are.

Recent extensions of the lifecycle model involve incentive based compensation schemes. In these models, firms provide a contract to workers to encourage them to maximize their effort and hence their productivity. Some argue that such contract models compliment human capital in explaining wages and other labor market phenomena; others argue that contract models substitute for the human capital model. The final part of this survey explores this question and concludes that one has to consider both types of models simultaneously in a unified framework to determine the relative merits of each.

\section{Stylized Facts: Earnings Heterogeneity across the Population}

To set the stage, examine Table 1 which shows how earnings differ for various demographic groups. As can be seen, women earn less than men, and black workers earn less than whites. For men earnings increase with age, but at a decreasing rate. For women, earnings vary less with age. In addition, earnings rise with education yet they vary across occupations. Earnings tend to be higher in urban areas. They tend to be lower in the southeast. In short, earnings are not uniform across the population, but instead vary based on a host of socioeconomic demographic characteristics. Indeed, Table 1 actually understates the variation in pay because even within each category pay varies considerably. Whereas classical economists who concentrated on the functional distribution of income, that is the portion of national income going to capital and labor as a whole, human capital theorists beginning with Mincer concentrate on the variation in earnings within labor as a whole. They seek to address, who earns high wages, and why? What makes some destitute and others better off? Why do wages vary across demographic groups the way they do? And finally, how can employers increase worker productivity? 


\section{III.The Theoretical Underpinnings: The Ben-Porath Model Lifecycle Model of Human Capital Investment over the Lifecycle}

Cognizance of the fact that wages vary across the population goes back at least to Adam Smith. Smith (1776) argued that to attract workers the competitive market would have to compensate workers to take jobs with undesirable characteristics. Whereas these notions of compensating wage differentials were mostly applied to the areas of workplace safety and health (Thaler and Rosen, 1976, and Kniesner and Leath, 1991, and Kniesner, Viscusi, Woock, and Ziliak, 2006), they are applicable to human capital and lifecycle earnings variations, as well.

According to the human capital approach, workers invest in schooling and other forms of training to enhance earnings. But training is costly. There are direct costs such as tuition, as well as foregone opportunities that reflect what one could have been doing, such as working for pay, while going to school or getting training. Wage differences between the more and less educated are simply the required compensation to adjust for the extra costs incurred in getting more human capital. As will be illustrated, in a competitive labor market, the "present value of net gain" over one's working life for jobs requiring more education compared to jobs attainable with less education is equated at the margin. In other words, one invests in training if one receives a rate of return at least as high as the market rate of interest, otherwise why not choose another type investment. If the units of training are divisible, for example into years of schooling or number of courses, then one purchases training up to the point the rate of return is just equated with the market interest rate, that is assuming diminishing returns. The problem is more complicated in a lifecycle context. Here, in each time period, an individual can purchase units of training, but as shall be explained the process is similar: In each time-period, one invests up to the point where the present value of marginal gains just equals the costs. 
Perhaps the first to rigorously examine the lifecycle investment process was Yoram Ben-Porath (1967). ${ }^{1}$ Under the assumption that investments in oneself enhances earnings, Ben-Porath devised a model in which individuals make investment decisions based on maximizing the present value of lifetime earnings. His innovation was to take advantage of the finite life constraint which implies that investment gains decline as one gets older. Declining investment gains lead to continually decreasing human capital investments which in turn imply that human capital stock and earnings power increase over the lifecycle, but at a decreasing rate. This process explains why most individuals acquire their schooling early in life, why geographic mobility is prevalent more among the young, and why earnings rise quickly for the young but taper off as workers age. In short, the life cycle approach explains the basic patterns for earnings as well as some aspects of job and geographic mobility.

This life cycle process can best be seen within the context of an optimization model. The individual maximizes his ${ }^{2}$ expected value of discounted earnings (one could also incorporate unearned income acquired through nonhuman capital investments as well) by appropriately allocating resources to human capital investment. These investments augment the individual's human capital stock, which in turn raises earnings power (though not necessarily actual observed take-home pay because some of the human capital stock is used to invest further). Current human capital stock is composed of last year's non-depreciated human capital augmented by new investment.

This process can be illustrated mathematically: If $\mathrm{K}(\mathrm{t})$ is human capital stock at time $t$; and $w$ is the rental rate (or wage) per unit of human capital; then wK(t) represents one's potential (though not necessarily actual) earnings. Note that all human capital receives the same wage, implying homogeneous human capital. The model also assumes no incentives to increase worker effort. (I return to the questions of homogeneous human

\footnotetext{
${ }^{1}$ Also see Eytan Sheshinski (1968). Gary Becker (1967) abstracts from the life cycle by dealing with investment decisions over the whole lifetime rather than in each phase of the life cycle.

${ }^{2}$ I use the term his because initial models dealt with workers who work continuously over their lifetime. Only later (e.g., Mincer and Polachek, 1974 and Polachek, 1975a) did models modify the approach to deal with discontinuous labor force participation, more typically exhibited by women, especially married women with children. Also, some have looked at this process within a family context. See Mincer (1978), Polachek (1975b), and Polachek and Horvath (1977).
} 
capital and worker effort later.) Actual earnings (the pay check one actually receives) are potential earnings $[\mathrm{wk}(\mathrm{t})]$ minus investment costs $[\mathrm{I}(\mathrm{t})]$ so that take home disposable earnings are $[\mathrm{wK}(\mathrm{t})-\mathrm{I}(\mathrm{t})]^{3}$. Investment costs $\mathrm{I}(\mathrm{t})$ consist of the cost of purchased inputs and foregone earnings. However, for simplicity one can assume all investment costs are opportunity costs so that $\mathrm{I}(\mathrm{t})$ simply equals $\mathrm{s}(\mathrm{t}) \mathrm{wK}(\mathrm{t})$ where $\mathrm{s}(\mathrm{t})$ is the time spent in period t investing in human capital.

Thus individuals seek to maximize the present value of lifetime earnings

$$
\operatorname{Max}_{s(t)} \int_{0}^{T} Y(t) e^{-r t} d t
$$

where $\mathrm{Y}(\mathrm{t})=[1-\mathrm{s}(\mathrm{t})] \mathrm{w} \mathrm{K}(\mathrm{t})$, by appropriately choosing the time they spend [s(t)] investing in human capital. ${ }^{4}$ As will be illustrated, investment has a benefit (increased future earnings) and as was illustrated a cost (foregone earnings); equating both cost and benefits at the margin in each year is the optimal strategy to maximize the present value of earnings.

To see this, write out the annual change in human capital as

$$
\dot{K}(t)=Q(t)-\sigma K(t)
$$

where $\dot{K}(t)=d K(t) / d t ; Q(t)$ is the amount of human capital created; and $\sigma$ is the depreciation rate of old human capital. New human capital $Q(t)$ is created by combining

\footnotetext{
${ }^{3}$ In this formulation, I ignore hours of work which can be brought in either of two ways: One possibility is to assume one works less than 24 hours per day to invest in mental health to preserve one's sanity. This approach makes labor supply a health investment decision. An alternative approach is to generalize the individual's objective function to maximize lifetime utility rather than maximize wealth. This latter approach adopted by Blinder-Weiss (1976), Heckman (1976), and Ryder et. al. (1976), and later modified to incorporate the feedback effect of human capital investments on future labor supply (Jiang and Polachek, 1991) embeds the traditional labor leisure labor supply model into the human capital acquisition process. Also see Shaw (1989) and Imai and Keane (2004).

${ }^{4}$ Uncertainty can be incorporated. For example, see Levhari and Weiss (1974), Snow and Warren (1990), Orazem and Mattila (1991) and Altonji (1993).
} 
one's own time $\mathrm{s}(\mathrm{t})$ with already existing human capital (I ignore purchased inputs) so that $Q(t)=f[s(t) K(t)]$, or $Q(t)=B[s(t) K(t)]^{\beta}$ if one takes a simple Cobb-Douglas.

The maximization problem entails setting up a Hamiltonian (the dynamic analogue to the LaGrangian multiplier)

$$
H=[(1-s(t)) w K(t)] e^{-r t}-\mu(t)[f(s(t), K(t))-\sigma K(t)]
$$

where each term is already defined with the exception of $\mu(t)$ which represents the present value of added human capital investment.

First order conditions dictate that individuals equate the marginal costs of investment time $[\mathrm{wK}(\mathrm{t})]$ to the marginal gains $\left[\mu(t) f_{s(t)}\right]$. Ben-Porath followed by Wallace and Ihnen (1975), Ryder, Stafford and Stephan (1976), Johnson (1978), and others describe several phases of investment. The initial phase resulting from a corner solution in the maximization process is pure specialization of investment -- what some call schooling. The precise definition depends on whether purchased goods can substitute for time as an input to produce human capital, whether human capital purchases are subsidized, and what one assumes about the individual's ability to borrow. During schooling human capital stock rises at an increasing rate. Though (for most definitions of school) there is no actual disposable earnings (since one specializes in learning rather than earning) potential earnings are rising at an increasing rate. (See Polachek and Siebert (1993), Chapter 3, especially Figure 3.3.)

During the next phase individuals both work and invest. This phase is either called post-school investment (PSI) or on-the-job training (OJT). One important result emerges during the OJT phase: For the typical human capital production function, time spent 
investing declines monotonically over the life cycle. ${ }^{5}$ This monotonically declining investment means that individuals annually create less human capital each year as they get older. The accumulated human capital (known as the human capital stock $\mathrm{K}(\mathrm{t})$ ) increases at a decreasing rate as does potential earnings which are proportional to the accumulated human capital stock (recall that earnings potential $\mathrm{E}(\mathrm{t})=\mathrm{w} \mathrm{K}(\mathrm{t})$ ).

Before applying the lifecycle approach to obtain a tractable empirical specification of earnings, one should note some of its basic assumptions. First, the model assumes individuals to be risk neutral. This implies that stochastic effects play no role in determining investment decisions. Second, the model assumes individuals know (with certainty) how many years they shall work over their lifetime. Third, the model assumes individuals work fully over their lifetime. Clearly full labor force participation throughout each person's life isn't always the case, especially since it is well known that both work hours and labor force participation vary over the life cycle, especially for women. Fourth, the model assumes all individuals are identical in every respect. This includes one's ability to create more human capital (that is, individual human capital production functions), one's commodity rate of time preference (in models incorporating leisure and labor supply), one's ability to borrow to finance human capital investment (applying to models in which purchased goods are important to human capital acquisition), and one's discount rate. Fifth, the model assumes human capital is homogeneous. Individuals differ in the amount of human capital they accumulate, but not in the type human capital. Sixth, the model assumes the rental rate per unit of human capital to be exogenously fixed over one's entire lifetime. Indeed how the human capital rental rate (w) is determined is neglected in human capital literature. Each of these limitations especially the sixth which has blossomed into a large literature on contracting type models are now being addressed have been addressed in the literature. Before addressing these modifications, I go on to the current model's implications with regard to earnings over the lifecycle.

\footnotetext{
${ }^{5}$ There are exceptions: For example, as will be discussed later, when the intermittent worker just re-enters the labor force after being out of the workforce for a long period of time (Polachek, 1975a). Also Ehrlich and Chuma (1990) show that health investments can rise because the gain in longevity increases as one approaches death.
} 


\section{The Mincer Earnings Function}

Mincer (1958, 1974) was the first to derive an empirical formulation of earnings over the lifecycle. In his formulation, at any point (t) in an individual's lifetime, observed earnings [which equals potential earnings wK(t) minus human capital investment (1$\mathrm{s}(\mathrm{t})) \mathrm{K}(\mathrm{t})$ ] can be depicted as a concave function of one's labor market experience. Assuming that the schooling phase of investment lasts $\mathrm{S}$ years and that on-the-job training declines linearly over the lifecycle, log-earnings are a quadratic function of labor market experience

$$
\ln Y_{i}(t)=a_{0}+a_{1} S_{i}+a_{2} t_{i}+a_{3} t_{i}^{2}+\varepsilon_{i}
$$

where $Y(t)=w K(t)-s(t) K(t) .{ }^{6}$ Here $\mathrm{a}_{0}$ is related to initial earnings capacity, $\mathrm{a}_{1}$ is the rate of return to education (assuming all schooling costs are opportunity costs), and $\mathrm{a}_{2}$ and $\mathrm{a}_{3}$ are related to both the amount and the financial return to on-the-job training. ${ }^{7}$ Equation (4) is often referred to simply as the Mincer earnings function. Mincer's derivation is ingenious, but even more important is the interpretation of the parameters $a_{0}, a_{1}, a_{2}$ and $a_{3}$. Both are given in the next section. Also illustrated in the next section are other functional forms of the Mincer earnings equation which unfortunately many scholars often forget. This is important because papers such as Murphy and Welch (1990) Heckman, Lochner, and Todd (2003), and Lemieuz (2006) unjustifiably criticize the $\log _{\mathrm{e}^{-}}$ linear Mincer model because they find the quartic fits better than the Mincer quadratic equation (Murphy and Welch, 1990) and that the percent increase in earnings attributable

\footnotetext{
${ }^{6}$ Heckman, Lochner and Todd (2003) modify the Mincer model to incorporate individuals choosing their education levels to maximize their present value of lifetime earnings. They also relax other restrictions such as the constraint that log earnings increase linearly with schooling and the constraint that log earningsexperience profiles are parallel across schooling classes, but Mincer also relaxes these constraints in a number of his specifications which contain an interaction term between experience and schooling. Indeed he finds (1974:92-3) nonparallel profile shifts, as well.

${ }^{7}$ A precise definition of these coefficients takes into account parameters describing the rate of investment and the rate of human capital depreciation. See Section V on the derivation of the Mincer earnings function as well as Jacob Mincer (1974) p. 21 and 91; Thomas Johnson (1970); and S. Polachek and W. S. Siebert (1993), Appendix 4.1.
} 
to schooling need not be independent of the amount of school or experience one has (Heckman, Lochner, and Todd, 2003). Indeed, in addition to (4), Mincer fits a number of earnings function specifications though he has no way to ascertain which is best. More on this shortly.

\section{Derivation of the Mincer Earnings Function ${ }^{8}$}

Define $\mathrm{C}_{\mathrm{t}}$ to be one's dollar investment on human capital in any year t. Then, $\mathrm{E}_{1}$, earnings in period one can be depicted as

$$
\mathrm{E}_{1}=\mathrm{E}_{0}+\mathrm{r} \mathrm{C}_{0}
$$

where $\mathrm{E}_{0}$ represents one's potential earnings based on innate ability, w $\mathrm{K}(0)$. Similarly,

$$
\mathrm{E}_{2}=\mathrm{E}_{1}+\mathrm{rC}_{1}=\mathrm{E}_{0}+\mathrm{rC}_{0}+\mathrm{rC}_{1}
$$

By recursion,

$$
E_{t}=E_{0}+r \sum_{i=0}^{t-1} C_{i} .
$$

Because it is empirically difficult to obtain data on dollar investment in human capital, Mincer defined the term $k_{t}=\frac{C_{t}}{E_{t}}$ to represent the proportion of one's earnings spent on investing in human capital. This proportion approximates the percent of one's time spent investing in human capital. It is known as "time-equivalent" investment and is equivalent to s(t) in the above Ben-Porath model. Substituting $k_{t}$ for $C_{t}$ above, yields

$$
E_{t}=E_{0} \prod_{i=0}^{t-1}\left(1+r k_{i}\right)
$$

\footnotetext{
${ }^{8}$ This section is based on Mincer (1974). See G. Becker and B. Chiswick (1966) for an alternative derivation
} 
Taking the logarithm of both sides yields

$$
\ln E_{t}=\ln E_{0}+\sum_{i=0}^{t-1} \ln \left(1+r k_{i}\right)
$$

The term $\ln \left(1+r k_{i}\right) \approx r k_{i}$ when $r k_{i}$ is small. Thus (A5) can be rewritten as

$$
\ln E_{t}=\ln E_{0}+r \sum_{i=0}^{t-1} k_{i}
$$

During school, $\mathrm{k}_{\mathrm{i}}$ equals one since schooling is essentially a full-time endeavor. However, according to the lifecycle model discussed above, after formal schooling ends, $\mathrm{k}_{\mathrm{i}}$ declines monotonically becoming zero when one retires from work. This implies $\mathrm{k}_{\mathrm{i}}$ can be divided into two parts: (1) a full-time schooling period in which $k_{i}=1$ for all $i$, and (2) a post-school investment period in which investments decline monotonically. As such, (10) can be rewritten as

$$
\ln E_{t}=\ln E_{0}+r_{s} S+r_{p} \sum_{i=0}^{t-1} k_{i} \cong \ln E_{0}+r_{s} S+r_{p} \int_{0}^{t} k_{j} d j
$$

where $r_{s}$ is the rate of return to schooling and $r_{p}$ is the rate of return to post-schooling investment, and when post-school investment is expressed in continuous time. Although theory dictates $\mathrm{k}_{\mathrm{j}}$ to monotonically decline, it does not indicate the rate of decline. Mincer experimented with four specifications: (1) linearly declining dollar post-school investment, (2) linearly declining time-equivalent post-school investment, (3) exponentially declining dollar post-school investment, and finally (4) exponentially declining time-equivalent post school investment. These yield four different earnings function specifications. The linearly declining time-equivalent post-school investment model is the most used function. Here Mincer assumes

$$
k_{t}=k_{0}-\frac{k_{0}}{T} t
$$


where $\mathrm{k}_{0}$ represents time-equivalent investment during the initial time period and $\mathrm{T}$ is the total number of periods in which investment is positive. ${ }^{9}$ One can examine this investment function graphically (left side of Figure 10 denoted continuous participation). Ben-Porath's "gross investment" function is depicted by Q(t). Mincer's "net investment" function is depicted by $\mathrm{k}(\mathrm{t})$; the difference reflects depreciation. Substituting (12) in (11) yields

$$
\ln E_{t}=\ln E_{0}+r_{s} S+r_{p} k_{0} t-\frac{r_{p} k_{0}}{2 T} t^{2}
$$

which indicates one's potential earnings are quadratic in work experience t. One problem: Actual earnings do not equal potential earnings because wage earners spend part of their earnings investing. Thus actual earnings

$$
Y_{t}=\left(1-k_{t}\right) E_{t}
$$

Taking the logarithm implies

$$
\ln Y_{t}=\ln E_{0}+r_{s} S+r_{p} k_{0} t-\frac{r_{p} k_{0}}{2 T} t^{2}+\ln \left(1-k_{t}\right)
$$

Plugging (12) in (15) yields

$$
\ln Y_{t}=\ln E_{0}+r_{s} S+r_{p} k_{0} t-\frac{r_{p} k_{0}}{2 T} t^{2}+\ln \left(1-k_{0}+\frac{k_{0}}{T} t\right)
$$

Taking a two-term quadratic Taylor approximation of $\ln \left(1-k_{0}+\frac{k_{0}}{T} t\right)$ yields earnings function (4) above, where

$$
\begin{aligned}
& a_{0}=\ln E_{0}-k_{0}\left[1+\frac{k_{0}}{2}\right] \\
& a_{1}=r_{s}
\end{aligned}
$$

\footnotetext{
${ }^{9}$ According to the Ben-Porath model individuals stop investing only in the time period just prior to retiring. This implies a positive investment throughout one's whole working life. However, actual human capital investment need not be positive because skills also depreciate at the same time one invests. At one point skills can depreciate more than appreciate. When this occurs "net" human capital investments turn negative.
} 


$$
\begin{aligned}
& a_{2}=r_{p} k_{0}+\frac{k_{0}}{T}\left[1+k_{0}\right] \\
& a_{3}=-\frac{r_{p} k_{0}}{2 T}-\frac{k_{0}{ }^{2}}{2 T^{2}}
\end{aligned}
$$

As indicated in Figure 10, the earnings function peaks at $\mathrm{T}$, then declines.

One instead can express the above Mincer equation in terms of Ben-Porath's gross investment, rather than net investment. Let $k_{t}^{*}$ be gross investment $=$ net investment + depreciation. Then,

$$
E_{t}=E_{t-1}+r C_{t-1}^{*}-\delta_{t-1} E_{t-1}
$$

implying

$$
E_{t} / E_{t-1}=1+r k_{t-1}^{*}-\delta_{t-1}=1+r k_{t-1}
$$

so that

$$
k_{t-1}=k_{t-1}^{*}-\left(\delta_{t-1} / r\right)
$$

One can use the above substitution in the above equation for $\ln Y_{t}$ to express observed earnings in terms of gross investment and depreciation:

$$
\ln Y_{t}=\ln E_{0}+r_{s} S+\sum_{i=0}^{t-1-S}\left(r_{p} k_{i}^{*}-\delta_{i}\right)+\ln \left(1-k_{t}^{*}\right)
$$

This specification is very much in the spirit of Johnson (1970). 
The Ben-Porath model indicates $\mathrm{k}_{\mathrm{t}}$ declines monotonically over the lifecycle, but does not specify the rate at which it declines. For this reason, Mincer considers three other specifications for $\mathrm{k}_{\mathrm{t}}$. then he derives empirical formulations: (1) a linear declining dollar specification, (2) the linearly declining time-equivalent investment specification just considered, (3) an exponentially declining dollar specification, and (4) an exponentially declining time-equivalent investment specification. These four specifications are given below:

$$
\begin{aligned}
& C_{t}=C_{0}-\frac{C_{0}}{T} t \\
& k_{t}=k_{0}-\frac{k_{0}}{T} t \\
& C_{t}=C_{0} e^{-\beta t} \\
& k_{t}=k_{0} e^{-\beta t}
\end{aligned}
$$

With corresponding earnings functions:

$$
\begin{aligned}
& Y_{t}=E_{S}+r C_{0} t-\frac{r C_{0}}{2 T} t^{2}-C_{0}+\frac{C_{0}}{T} t=E_{S}-C_{0}+C_{0}\left(r+\frac{1}{T}\right) t-\frac{r C_{0}}{2 T} t^{2} \\
& \ln Y_{t}=\ln E_{0}+r_{S} S+r_{t} k_{0} t-\frac{r k_{0}}{2 T} t^{2}+\ln \left(1-k_{t}\right) \\
& Y_{t}=E_{S}+r \frac{C_{0}}{\beta}-r \frac{C_{0}}{\beta} e^{-\beta t}-C_{0} e^{-\beta t}=E_{S}+r \frac{C_{0}}{\beta}-\frac{C_{0}}{\beta}(r+\beta) e^{-\beta t} \\
& \ln Y_{t}=\ln E_{S}+\frac{r}{\beta} k_{0}\left(-\frac{r k_{0}}{\beta}\right) e^{-\beta t}+\ln \left(1-k_{0} e^{-\beta t}\right)
\end{aligned}
$$


Mincer estimates each of these using the 1960 Public Use U.S. Census data, now readily available on the internet. Below I present his estimates for three specifications. The first is equation (23) described above, and the second and third are forms of (25).

$$
\begin{aligned}
& \ln Y=6.20+.107 S+.081 t-.0012 t^{2} \\
& \ln Y=7.43+.110 S-1.651 e^{-.15 t} \\
& \ln Y=7.52+.113 S-1.52 e^{-.10 t} .
\end{aligned}
$$

One can utilize the above equations to solve for the underlying earnings function parameters. Take the first equation representing linearly declining post-school investment. There are four coefficients representing five parameters. Thus one must make an identifying restriction. If we were to assume equal rates of return for schooling and post-school investment $\left(\mathrm{r}_{\mathrm{s}}=\mathrm{r}_{\mathrm{t}}\right)$ then $\mathrm{Y}_{0}$ would equal $\$ 1185.59$ in 1960 dollars, which reflects the earnings power of an individual with no human capital. The initial timeequivalent investment just upon completing school $\mathrm{k}_{0}$ would equal 0.492 meaning that one initially spends about $50 \%$ of the time on one's first job investing in on-the-job training. Finally, T would equal 25.82, implying that earnings peaks just after 25 years in the labor force. ${ }^{10}$ Next, take the second and third equations. The second assumes the exponential decay rate of time-equivalent human capital to be $15 \%$ (that is, $\beta=-.15$ ) and the third $10 \%$. Using this information along with the estimated parameters implies $\mathrm{Y}_{0}$ to be $\$ 1168$, $\mathrm{k}_{0}$ to be $.80, \mathrm{r}_{\mathrm{s}}$ to be .107 and $\mathrm{r}_{\mathrm{t}}$ to be .07 for the second equation. The third equation yields $\mathrm{Y}_{0}$ to be $\$ 879, \mathrm{k}_{0}$ to be $.57, \mathrm{r}_{\mathrm{s}}$ to be .11 and $\mathrm{r}_{\mathrm{t}}$ to be .13 .

\footnotetext{
10 The computation is as follows:

Solve $\ln Y-k\left(1+\frac{k}{2}\right)=6.2 ; r_{s}=.107 ; r_{t} k+\frac{k}{T}(1+k)=.081 ;-r_{t} \frac{k}{2 T}+\frac{k^{2}}{2 T^{2}}=-.0012 ; r_{s}=r_{t}$ for $T, k, r_{s}, r_{t}$, and $Y$.
} 
In these computations, it is interesting to note that $\mathrm{k}_{0}$ ranges between 0.5 and 0.8 . These figures are far below 1.0, as one would expect when an individual just completes school (Polachek and Siebert, 1993:28). According to the Ben-Porath optimization model, human capital investment declines continuously over one’s lifetime. Investment time just after completing school should be slightly below 1.0, but not as low as the 0.5 to 0.8 range observed above. One explanation centers on governmental and familial subsidies to those attending school (Johnson, 1978). According to this argument, school enrollees receive subsidies if and only if they remain in school. To obtain the maximum subsidy, individuals stay in school longer than otherwise, but revert back to regular investment patterns when the subsidy disappears.

In addition to the above earnings function formulations, Mincer experiments with a quadratic in school to test for nonlinearities in the rate of return to education, and an interaction term between school and experience to test whether earnings profiles are parallel across schooling levels. He finds

$$
\ln Y=4.87+.255 S-.0029 S^{2}-.0043 t \cdot S+.1481 t-.0018 t^{2} .
$$

This implies rates of return to school decrease with length of school and labor market experience. It also implies nonparallel earnings profile shifts as schooling rises.

\section{Direct Applications of the Mincer Earnings Function}

The Mincer earnings function yields at least three important empirical implications. First, it argues that earnings levels are related to human capital investments. This means the more human capital investments an individual makes the higher his or her earnings. Further, the coefficient on the schooling variable reflects the rate of return to schooling. As such, given relatively competitive markets, empirical analysis should yield schooling coefficients in the range of common interest rates. Borrowing and other constraints on human capital investments could alter these rates, but not too greatly. Accordingly, earnings should be related to the quality of schooling. Those attending 
higher quality schools should earn more. Assuming the market rewards productivity, higher earnings should reflect higher actual productivity. Second, earnings functions are concave. Earnings rise more quickly for the young, then earnings growth tapers off midcareer. Third, the model has implications regarding the distribution of earnings. For example, because human wealth is the present value of lifetime earnings, the distribution of earnings should exceed the distribution of "human wealth." Thus the variation in earnings should exceed the variance in human wealth as measured by the present value of the earnings stream. Also holding schooling level constant relative earnings differences (for example measured as the variance of the logarithm of earnings across the population) should narrow with experience then widen. Thus experience profiles of the log variance of earnings should be U-shaped. This section is divided into three parts, each presenting evidence on these implications.

\section{A. The Rate of Return to Education}

The positive correlation between earnings and schooling is so evident in the literature that one cannot do justice to the extensive rate of return literature. Schooling rates of return have been measured for literally dozens of countries and for many years. One recent survey (Psacharopoulos and Patrinos, 2004) contains rate of return estimates for over 70 countries spanning more than 25 years. Another (Trostel, Walker and Woolley, 2002) contains estimates for 28 countries. In a special issue of Labour Economics devoted solely to issues estimating schooling rates of return, Ashenfelter et al. (1999) notes that current rate of return studies "provide us strong evidence that schooling is a powerful investment in a wide variety of settings" (Ashenfelter et al.: viii). Chiswick, Lee and Miller (2003) confirm this using data from the 1996 Australian Survey of Aspects of Literacy by in essence showing that "education is a value-added process in which skills, including literacy and numeracy, are improved....” Similarly, Gabriel and Schmitz (2005) confirm the positive correlation between schooling and earnings using data from the 2003 Current Population Survey to estimate rates of return to education across occupational categories in the U.S. labor market. They find that "additional 
schooling has a positive impact on the weekly earnings of men and women in both whiteand blue-collar occupations.”

Table 2 contains cross-sectional rate of return estimates computed for 41 countries. These estimates are computed using equation (4) fit to cross-sectional data. The first six columns use data from various years of the International Social Survey Programme (ISSP) and the latter three columns use data from various years of the Luxembourg Income Study (LIS). At least several observations are noteworthy. First, the magnitudes of the rate of return estimates are positive. These positive magnitudes mean that investments in school yield higher earnings, just as the human capital model predicts. Second, the magnitudes vary from about 3\% to almost 17\%. Such returns are comparable to high grade bonds available in modern financial markets. Third, and not well understood, rates of return tend to be (but are not always) slightly higher for women than men. Fourth, rates of return are often higher in less developed countries. These observations are robust for virtually all countries for which there are data and all econometric specifications. As will be discussed later, some have questioned the magnitude of these rates of return because of potential econometric biases. These will be discussed later.

Not only are schooling levels and wages positively correlated, but data also indicate that school directly enhances real output. Zvi Griliches (1963, 1964) used aggregate state (and regional) data to find far higher farm production in states with higher education levels. Utilizing more accurate productivity data on 296 household farms in West Bengal, India, Kumbhakar (1996:188) showed "that education increases [actual] productivity” and that this enhanced productivity increased farmers' wages. Using unique data detailing the biographies of Palestinian suicide bombers, Benmelech and Berrebi (2006) find that more educated suicide bombers are more likely to succeed in their mission and are more likely to induce casualties when they attack. Generalizing these results to economic growth, Barro and Sala-i-Martin (1999) find that the higher a population's education, the higher its GDP and GDP growth per capita. Also, educated immigrants assimilate far more quickly into the U.S. economy (Borjas, 1993). Thus 
education has direct measurable effects on productivity and labor market success. In addition, education positively affects non-labor market activities. For example, Michael (1973) shows that education improves one's efficiency in consuming everyday commodities. Polachek and Polachek (1989) illustrate "reverse intergenerational transfers” by showing that even one's children's education positively affects the way one consumes. Finally, Lochner and Moretti (2004) show that schooling reduces the probability of incarceration and arrest.

\section{B. Earnings Function Concavity}

Turning back to the earnings function and post-school investment, there is another finding that is also virtually universal. This widespread result is "earnings function concavity," resulting from the negative $a_{3}$ coefficient found when estimating equation (4). This means for those continuously attached to the labor market, earnings rise at a decreasing rate throughout one's life until depreciation exceeds human capital accumulation. Early studies (Mincer, 1974) tested this proposition using OLS regression with cross-sectional data. ${ }^{11}$ This result is universal across countries and years. For example, Table 3 contains cross-sectional Mincer earnings functions for 25 countries and various years. The t-squared quadratic coefficient is always negative. Gautier and Teulings (2003) also present strong evidence for the concavity for six OECD countries. Further, these results also hold when one adjusts for selectivity biases (Hartog, et al., 1989; Kiker and Mendes de Oliveira, 1992; or Baldwin, Zeager, and Flacco, 1994, and Gibson and Fatai, 2006) and for individual specific heterogeneity (Mincer and Polachek, 1978; Licht and Steiner, 1991; Kim and Polachek, 1994; Light and Ureta, 1995).

\section{Distribution of Earnings Over the Lifecycle: The Overtaking Point}

\footnotetext{
${ }^{11}$ Some exceptions are in panel data, but one can question how to adjust for price changes. Another exception is in executive pay late in some individuals' career paths.
} 
Perhaps one of the more unique, interesting, but rarely explored concepts to emerge from Mincer's earnings function formulation is the "overtaking point." The overtaking point is the moment in one's lifecycle when observed earnings just equals one's potential earnings at graduation, were there no post-school investment. As illustrated in Figure 1 (Mincer, 1974:17), the concave curve $Y_{0} Y_{j} Y_{P}$ plotted over the lifecycle reflects observed earnings, which are potential earnings ( $E_{j}$ depicted by curve $Y_{S} E_{j} Y_{P}$ ) minus (net) human capital investments $C_{j} \cdot{ }^{12}$ At the overtaking point $\hat{j}$, observed earnings $Y_{\hat{j}}$ equal potential earnings upon graduation, so that $Y_{\hat{j}}=E_{0}=Y_{S}$.

To derive the overtaking point, Mincer rigorously specifies the experience level at which observed earnings just equals one's earnings potential at graduation. This is point $\hat{j}$ when $Y_{S}=Y_{\hat{j}}$ (again refer to Figure 1, taken from Mincer, Figure 1.2, page 17). Recall that upon graduation, one invests a portion of potential earnings $Y_{S}$ in on-the-job training. This investment lowers observed earnings to $Y_{0}=Y_{S}-C_{0}$. Observed earnings then rise as one begins to accumulate the returns from investments $C_{t}$. Thus according to Mincer,

$$
Y_{\hat{j}}=Y_{s}+r \sum_{t=0}^{j-1} C_{t}-C_{j}=Y_{s}
$$

occurs when $\mathrm{r} \sum_{t=0}^{j-1} C_{t}=C_{j}$. If human capital investment $\left(C_{t}\right)$ occurring from $t=0$ through $t=\hat{j}$ is constant, then $r \hat{j} C_{j}=C_{j}$ implying $\hat{j}=\frac{1}{r}$. If $C_{t}$ declines between time 0 and $\hat{j}$, then the overtaking number of years can be expressed as $\hat{j} \leq \frac{1}{r}$.

\footnotetext{
${ }^{12}$ Net investment equals gross human capital investments minus depreciation. See Polachek and Siebert (1993) Chapter 2 for an exposition and diagrams contrasting gross and net investment.
} 
The overtaking point enables one to observe what one would have earned upon graduation at each level of schooling. This knowledge facilitates computing schooling rates of return. Simply compare $Y_{\hat{j}}$ at each schooling level $S_{i}$. Percentage earnings differences reflect the impact of schooling and define rates of return (assuming all schooling costs are opportunity costs). Indeed at $\hat{j}$ the Mincer "Schooling Model” should work best. Empirical tests (Brown, 1980) somewhat (but not completely) corroborate this.

The overtaking point is also important to get at some interesting implications regarding earnings distribution. Define $\sigma^{2}\left(Y_{j}\right)$ to be the variance of earnings, and define $\sigma^{2}\left(\ln Y_{j}\right)$ to be the relative earnings variance. According to Mincer, $\sigma^{2}\left(Y_{j}\right)$ and $\sigma^{2}\left(\ln Y_{j}\right)$ must vary over the life cycle. The pattern of variation depends on the dispersion in post-school investments and the correlation between post-school investment and earning capacity (Mincer, 1974: 98-103). “If ... the correlation between (dollar) schooling and post-school investment is positive ... dollar variances must rise from overtaking to peak earnings. In addition, dollar variances will rise throughout if $\sigma^{2}\left(Y_{0}\right)<\sigma^{2}\left(Y_{\hat{j}}\right) \ldots$ ”(Mincer, 1974:98). In contrast, $\sigma^{2}\left(\ln Y_{i}\right)$ is more likely to be Ushaped (Mincer, 1974:103).

Mincer illustrates the validity of these conjectures in two Figures, reproduced below as Figures 2 and 3. Given the uniqueness of these results, Polachek (2003) examined whether these patterns generalize to the U.S. and to the economies of other country. He used the 1980 and 1990 Census to examine U.S. earnings variations over the life cycle. ${ }^{13}$ To avoid confounding earnings distribution with gender and race, and to

\footnotetext{
${ }^{13}$ For consistency as well as because of data limitations, he followed Mincer's approach of using a "crosssectional" cohort. This means he compared earnings data for variously aged individuals in a given year. Interpreting these age comparisons to reflect purely lifecycle (age) effects requires one to assume that both cohort effects and time-period effects are negligible. Thus one must assume that observations on each successive age group represents the effect of a given cohort of individuals getting older and not the effect of being born in the following year (cohort effect) or the effect of having earnings measured in a successive year (time-period effect). Researchers have long recognized that true cohort and cross-sectional profiles differ. Further it would be a mistake to simply add general growth rates of real earnings to growth
} 
conform to Mincer (1974), he concentrated on white males. ${ }^{14}$ As will be explained later, using women would be interesting but the results would not be comparable because on average their lifetime labor force participation is so different from males that their human capital investment function would be non-monotonic over their lifetime, resulting in lower and flatter non-concave earnings functions (Polachek, 1975a). Most likely these earnings profile differences would also affect women's earnings distributions. To circumvent labor supply issues, he examined hourly earnings (computed as annual earnings divided by a measure of hours worked per year). As an illustration four of Polachek's graphs corroborating Mincer's findings are given in Figures 4-7. One set represents Australia in 1981 and another Canada in 1997. Two figures are presented for each case: one for the standard deviation of dollar hourly earnings $\sigma(Y)$ over the life cycle and another for the standard deviation in relative hourly earnings $\sigma(\ln Y)$. Polachek's results confirm what Mincer originally found. First, the standard deviation of the logarithmic wage profile is U-shaped, while the lifecycle pattern of the standard deviation in dollar wage is not. Second, for Figures 5 and 7 (as well as for the U.S. in 1980 which is not shown here), the trough is at about 20 years of experience. Each of these observations is consistent with Mincer's expectation.

\section{Econometric Issues Regarding Estimation of the Mincer Earnings Function}

A number of econometric issues arise in estimating the earnings function. We deal with several.

rates of earnings associated with age, because at least recently, age-earnings profiles grew differently for individuals with higher levels of education than those with lower levels of education. For example, see Beaudry and Green (2000) who illustrate this with the Canadian Surveys of Consumer Finance and the Canadian Census. Also see Heckman and Robb (1985).

${ }^{14}$ Using women would be interesting but the results would not be comparable because on average their lifetime labor force participation is so different than males that their human capital investment function is non-monotonic resulting in lower and flatter non-concave earnings functions (Polachek, 1975a). Most likely these earnings profile differences also affect women's earnings distributions. 


\section{A. Functional Form Specification}

As already mentioned, the most popular version of the Mincer earnings function is log-linear, emanating from the linear declining post-school investment function. However, other functional forms have been used in the literature. For example, Thurow (1969) used a log-log model based on assuming that earnings are produced by a CobbDouglas production function. Of course, the simplest functional form is simply a linear relationship between schooling and earnings. Which functional form is correct? Is it the completely linear model, the Mincer log-linear model, or the Thurow log-log model? Heckman and Polachek (1973) applied Box-Cox and Box-Tidwell models to let the data themselves reveal the appropriate functional form.

To apply Box-Cox and Box-Tidwell techniques one must rerun the earnings function with data transformed as follows:

$$
\frac{y_{i}^{\tau_{0}}-1}{\tau_{0}}=\beta_{0}+\sum_{j} \beta_{j} \frac{x_{i}^{\tau_{j}}-1}{\tau_{1}}+\varepsilon_{i}
$$

where $y$ denotes earnings, $\mathrm{x}$ is a vector denoting schooling and experience, $\tau$ and $\beta$ are parameters to be estimated, and $\varepsilon$ is the error term.

Because (28) is nonlinear in the parameters, it makes sense to adopt a nonlinear maximum likelihood approach. Assuming a normal error, the log-likelihood function is

$$
\ln (L)=-\frac{T}{2} \ln (2 \pi)-\frac{T}{2} \ln S^{2}+\left(\tau_{0}-1\right) \sum_{i=1}^{T}\left(\frac{y_{i}^{\tau_{0}}-1}{\tau_{0}}-\sum_{j} \beta_{j} \frac{x_{i}^{\tau_{j}}}{\tau_{j}}\right)
$$

where $S^{2}$ equals the mean error sum of squares and $\mathrm{T}$ equals the number of observations.

The neat thing about the approach is that $\tau$ is estimated as a parameter. The optimal value of $\tau$ indicates the appropriate functional form for the earnings function. For example if $\tau=1$ then the variable is linear because $\left(\mathrm{y}_{1}-1\right) / 1=\mathrm{y}-1$. Similarly $\left(\mathrm{y}_{0}\right.$ - 
1) $/ 0=\ln$ y which can be derived by applying L'Hospital's rule. One can make a confidence band around the estimated point value of $\tau$ : $\operatorname{Pr}\left(\ln L_{\max } \tau_{\mu}-\frac{1}{2} \chi^{2}{ }_{\mathrm{df}, \alpha} \leq L_{\max } \tau_{i}\right)=1-\alpha$. The data from the article indicate that the Mincer $\log _{\mathrm{e}}$-linear specification fits the data best, though it is not perfect. Murphy and Welch (1990) also experiment with functional forms using cubic and quartic specifications. Hungerford and Solon (1987: 176) divide schooling into categorical dummy variables and find that rates of return to school "increase discontinuously in diploma years." Jaeger and Page (1996) utilize information on actual diplomas received to confirm more specifically these sheepskin effects.

\section{B. Omitted and Mis-measured Variables}

It is interesting to note that when Mincer originally fit his original earnings function in 1958, he used an abbreviated "schooling model" of the form

$$
\ln Y(t)=a_{0}+a_{1} S
$$

which omits the experience and experience-squared terms. Omitted variables lead to biased results if the omitted variable is correlated with the dependent as well as the remaining independent variables. To illustrate, note that experience and schooling are negatively correlated. Holding age constant, those with more schooling have less experience. Thus $\rho(s, t)<0$. But both schooling and experience are positively correlated with earnings. This means omitting experience (and experience-squared) leads to a downward biased schooling coefficient. Mincer illustrates this. Recall Mincer’s earnings function estimates using 1960 US Census data given in Section V. The relevant equation is:

$$
\ln Y=6.20+.107 S+.081 t-.0012 t^{2}
$$


To see how omitting the experience variables affect the computed rate of return, simply estimate the earnings omitting the experience terms. This yields

$$
\ln Y(t)=7.58+.070 S \text {. }
$$

As expected, the estimated schooling rate of return decreases from 0.107 to 0.070 .

The same logic applies to variables omitted from the original Mincer earnings function. For example, time out of the labor force (the number of years a person doesn't actually work perhaps because of family responsibilities bringing up children) is usually omitted. This omission leads to an overestimate of the experience coefficient because such "home time" is negatively correlated with both earnings and experience. Thus we observe those with little experience to have lower earnings than otherwise because time out of the labor force lowers their earnings from what it would be if they did not drop out of the labor force, and raises earnings for those with greater levels of experience because those workers are less likely to have dropped out. Similarly Kniesner, Padilla and Polachek $(1978,1980)$ show that aggregate economic conditions affect measured rates of return to schooling. Thus omitting area unemployment rates can bias rate of return estimates. This is especially true when comparing rate of return estimates across demographic groups such as when comparing black and white returns to schooling.

Nowadays most earnings functions include numerous supplementary variables in addition to the schooling and potential experience terms used by Mincer. These include race, gender, regional dummy categorical variables, health status, ethnicity, martial status, children, union membership, city size, and numerous other variables. They serve as exogenous "control variables" which essentially shift the earnings function upward or downward depending on sign. The coefficients on some, such as gender or race, are often interpreted as discrimination since they allegedly indicate how earnings levels differ between otherwise similar individuals. Many interpret the coefficients of other variables to represent the effects these variables have on earnings holding "levels of human capital” constant. Thus, Lewis (1986) interprets the positive union coefficient as the wage 
premium associated with union membership. Clark, Kahn and Ofek (1988) interpret the city size coefficients (fit with a parabolic and cubic specification) to reflect a city's amenities. (In their work residents in cities like Detroit receive a high wage whereas residents in cities like New York receive a low wage premium.) Jones and Richmond (2006) interpret the alcoholism coefficient as the productivity losses attributable to alcoholism.

Because variables such as gender and race are often correlated with earnings as well as schooling and experience, the original Mincer earnings function parameters need not accurately reflect those of the entire population. As such, earnings function parameters can differ by race, gender, or location. For example, some studies have found the schooling coefficients to be larger for women (Dougherty, 2003). On the other hand, experience and experience-squared terms are often smaller for women than men.

The problem of interpreting the earnings function coefficients is further complicated because a number of independent variables are measured incorrectly. For example, experience (originally measured by Mincer as age-minus-education-minus-six) is typically overstated for those women who often exhibit interrupted work over the lifecycle. Overstating experience yields smaller than true earnings function gradients, which also accounts for the flatter female earnings functions.

\section{Selectivity}

Another possible bias is sample selectivity. Sample selectivity biases come about because the data used in the estimation are nonrandom. Worrying about nonrandom observations in a regression has been a problem many have paid lip service to for a long time. Gronau (1974) addressed the question with regard to earnings functions. He argued that studies may underestimate the gender wage gap because many more women than men are not in the labor market. If the sample of women in the labor market is random 
then the fact that a greater proportion of women are out of the labor force wouldn't bias the estimate of the male-female wage differential. However, one may suspect the sample of working women to be nonrandom since one works only when one's offer wage exceeds one's reservation wage. Thus those in the labor market are only those for which $\mathrm{w}_{\mathrm{o}}>\mathrm{w}_{\mathrm{r}}$. This means that unless there is a correlation between reservation and offer wages, the women in the labor force are the ones that would receive the highest wages. Those not working could be "losers" in the sense that they did not obtain a sufficiently high salary to exceed their reservation wage. This means that if we were to include those not working in our earnings function estimating male-female wage differentials we would obtain a higher male-female wage gap. (One can also argue, as does Willis and Rosen (1979) that those who go to school longer are the ones with the highest expected rates of return, otherwise these individuals would have quit school earlier, the estimate of the union-nonunion wage gap, as well as other phenomena estimated using the Mincer equation.)

Gronau develops a way to account for this selectivity bias using aggregate data. However, a more general approach to solve the selectivity problem was introduced by Heckman (1979). He developed a two-equation simultaneous model to solve the problem.

$$
\begin{aligned}
& Y_{1 i}=x_{1 i} \beta_{1}+U_{1 i} \quad(i=1, \ldots, I) \\
& Y_{2 i}=x_{2 i} \beta_{2}+U_{2 i}
\end{aligned}
$$

where the error terms obey the usual properties: $E\left(U_{j i}\right)=0, E\left(U_{j i} U_{j^{\prime} i^{\prime}}\right)=\sigma_{j j^{\prime}}$ if $i=i^{\prime}$, and $\sigma_{\mathrm{jj}}=0$ if $i \neq i^{\prime}$ and where the joint distribution of $U_{1 i} U_{2 i}$ is $h\left(U_{1 i} U_{2 i}\right)$. He assumes the population regression for (11a) to be $E\left(Y_{1 i} \mid x_{1 i}\right)=x_{1 i} \beta_{1}$ and the sub-sample regression for (11a) to be $E\left(Y_{1 i} \mid x_{1 i}\right.$ and sample selection rule $)=x_{1 i} \beta_{1}+E\left(U_{1 i} \mid\right.$ sample selection rule). If one assumes there are data available on $Y_{1 i}$ if $Y_{2 i}>0$, and there are no data available on $\mathrm{Y}_{1 \mathrm{i}}$ if $\mathrm{Y}_{2 \mathrm{i}}<0$, then $\mathrm{E}\left(\mathrm{U}_{1 \mathrm{i}} \mid \mathrm{x}_{1 \mathrm{i}}\right.$ and selection rule $)=\mathrm{E}\left(\mathrm{U}_{1 \mathrm{i}} \mid \mathrm{x}_{1 \mathrm{i}}, \mathrm{Y}_{2}>0\right)=$ $\mathrm{E}\left(\mathrm{U}_{1 \mathrm{i}} \mid \mathrm{x}_{1 \mathrm{i}}, \mathrm{U}_{2 \mathrm{i}}>-\mathrm{x}_{2 \mathrm{i}} \beta_{2}\right)$ which implies $\mathrm{E}\left(\mathrm{Y}_{1 \mathrm{i}} \mid \mathrm{x}_{1 \mathrm{i}}, \mathrm{Y}_{2 \mathrm{i}}>0\right)=\mathrm{x}_{1 \mathrm{i}} \beta_{1}+\mathrm{E}\left(\mathrm{U}_{1 \mathrm{i}} \mid \mathrm{U}_{2 \mathrm{i}}>-\mathrm{x}_{2 \mathrm{i}} \beta_{2}\right)$ Based on $\mathrm{h}\left(\mathrm{U}_{1 \mathrm{i}}, \mathrm{U}_{2 \mathrm{i}}\right)$ being bivariate normal, 


$$
\mathrm{E}\left(\mathrm{U}_{1 \mathrm{i}} \mid \mathrm{U}_{2 \mathrm{i}}>-\mathrm{X}_{2 \mathrm{i}} \beta_{2}\right)=\frac{\sigma_{12}}{\sqrt{\sigma_{22}}} \lambda_{\mathrm{i}}
$$

and

$$
\mathrm{E}\left(\mathrm{U}_{2 \mathrm{i}} \mid \mathrm{U}_{2 \mathrm{i}}>-\mathrm{X}_{2 \mathrm{i}} \beta_{2}\right)=\frac{\sigma_{22}}{\sqrt{\sigma_{22}}} \lambda_{\mathrm{i}}
$$

where $\lambda_{i}=\frac{\phi\left(Z_{i}\right)}{1-\Phi\left(Z_{i}\right)}=\frac{\phi\left(Z_{i}\right)}{\Phi\left(-Z_{i}\right)}$ is the inverse Mills ratio and where $\phi$ density function and $\Phi$ distribution function of a standard normal variable $\mathrm{Z}_{\mathrm{i}}=-\frac{X_{2 i} \beta_{2}}{\sqrt{\sigma_{22}}}$. The conditional regression for the select sample is: $\mathrm{Y}_{1 \mathrm{i}}=\mathrm{x}_{1 \mathrm{i}} \beta_{1}+\frac{\sigma_{12}}{\sqrt{\sigma_{22}}} \lambda_{\mathrm{i}}+\mathrm{V}_{1 \mathrm{i}}$ and $\mathrm{Y}_{2 \mathrm{i}}=$ $\mathrm{x}_{2 \mathrm{i}} \beta_{2}+\frac{\sigma_{22}}{\sqrt{\sigma_{22}}} \lambda_{\mathrm{i}}+\mathrm{V}_{2 \mathrm{i}}$

This has led to a two-step estimation process where first one estimates the inverse Mills ratio and then, second, one plugs these inverse Mills ratios into the first equation for each observation. This technique has become popular not just with regard to applying the Mincer earnings function, but in numerous other social science areas. For example Falaris (1995) uses Venezuelan data to show that estimates of rates of return to schooling for married women in 1981 suffers from selectivity biases. Gibson and Fatai (2006) use data from urban Papua New Guinea to show that the rate of return to education is not sensitive to controls for sample selectivity bias. Modesto (2003) shows that in the Portuguese educational system rates of return to education vary between 2.4 and 9.4 percent, depending on whether or not selectivity and that selectivity represents three quarters of this difference. Hartog, Pfann, and Ridder (1989) show that dropouts behave differently from graduates so that selectivity plays a role in estimating rates of return to education among the Dutch. And, Constant and Massey (2003) use 14 years of longitudinal data to show that emigrants are negatively selected with respect to occupational prestige and to stable full time employment, but that selectivity does not appear to distort cross-sectional estimates of earnings assimilation of immigrants to Germany. 
A number of alternative modifications to Heckman's original development of a selectivity bias have evolved (Olsen, 1980; Lee, 1982, 1983; and Dubin and McFadden, 1984) including semi-parametric approaches (Dahl, 2002). Often at issue is the robustness of the technique which is highly sensitive to misspecification of the distribution of $\mathrm{U}_{1 \mathrm{i}}$ in equation (1a) (Goldberger 1980 and Barnow, Cain, and Goldberger, 1996; and Little 1985).

\section{Unobserved Heterogeneity}

Multivariate regression analysis, including simultaneous equations estimation incorporating corrections for selectivity-biases is based on observable individual characteristics so as to "hold constant" individual factors that affect earnings. One problem with such analysis is there are often important variables that should be incorporated, but they are omitted because there are no data on these "unobservables." For example, one can argue that smarter individuals get more out of an additional year of schooling compared to others, not necessarily because smarter individuals learn more, but because smarter individuals naturally command more earnings independent of school. If the more able also go to school longer, then the schooling coefficient in a typical earnings function would be biased upward because part of the return attributed to schooling really comes from unmeasured ability. ${ }^{15}$ Put simply, omitting ability overestimates the rate of return to education. However, measuring ability is quite difficult if not impossible since many claim that IQ and other type tests fail to get at true ability. As such, regressions run using individual data omitting unobserved ability are biased because unobserved heterogeneity contaminates the sample.

\footnotetext{
15 The same can be said for coefficients other than schooling, as well. For example, many argue that unionized workers are of better quality than non-union workers. If such is the case, the union coefficient overstates the "true" union-nonunion wage gap.
} 
One way to circumvent this problem is to find instruments for schooling and apply two-stage least squares. These instruments should mimic schooling but be uncorrelated with the error term and hence have no direct effect on earnings. In practice it is extremely difficult to find valid instruments. Furthermore, the bias may be exacerbated if the instruments explain a small part of the variance of the endogenous regressor.

Another solution is to find individuals who are known through genetics to have the exact same ability, but for some random reason vary in the amount of school they obtain. To do this one can get data on monozygotic (identical) and dizygotic (fraternal) twins since it is well known that monozygotic twins have an identical genetic structure, given they come from the same egg and sperm whereas dizygotic twins do not since they come from two eggs and two sperm. ${ }^{16}$ One can alleviate the bias by running regressions on difference in earnings between the two twins as a function of differences in twin schooling levels. Here, the schooling coefficients should be unbiased for monozigots because there is no difference in ability. ${ }^{17}$ As a result the measured rate of return to schooling should be smaller than the schooling coefficient obtained from a similar regression on fraternal twins or non-twin siblings.

Perhaps the first to perform this experiment was Taubman (1976) utilizing the National Academy of Sciences National research Council (NAS-NRC) Twin Sample with information on male twins born between 1917 and 1927 who served in the military during World War II. His results, duplicated in Table 4, indicate a 2.7\% rate of return for monozygotic twins and a 5.9\% rate of return for dizygotic twins indicating an approximately a 50\% ability bias. Ashenfelter and Rouse (1998) find a much smaller ability bias using data on approximately 700 identical twins in a survey based on attendees at the 1991, 1992, and 1993 Twinsburg, Ohio Twins Festivals.

\footnotetext{
${ }^{16}$ Researchers have actually discovered a third twin classification denoted as semi-identical twins in which two sperm cells fertilize one egg — an event assumed to be very rare- then split into two embryos. See http://www.msnbc.msn.com/id/17804318/.

${ }^{17}$ Bound and Solon (1999) question whether this ability bias is actually alleviated. They argue the twins' difference in school attendance and IQ might be brought about by the twins' difference in birth weights.
} 
A related approach to alleviate unobserved heterogeneity is to do first difference (or alternatively mean deviation) regressions based on observing a given person before and after a particular event. By comparing these changes for the same individuals also eliminates heterogeneity biases assuming unobserved characteristics do not change for given individuals. This is easy to see analytically. Return to the Mincer earnings function (4), but now assume an error structure containing an individual specific term $\left(\gamma_{i}\right)$ in addition to the typical random error $\left(\varepsilon_{i}\right)$. Note that to do this one needs panel data to follow individuals over time. As such, I change the notation somewhat by now denoting $t$ to be the time subscript for each variable, and $e$ (instead of $t$ ) to represent experience.

$\ln Y_{i t}=a_{0}+a_{1} S_{i t}+a_{2} e_{i t}+a_{3} e_{i t}^{2}+\gamma_{i}+\varepsilon_{i t}$

Taking the first difference eliminates the individual specific parameter $\gamma_{i}$ but preserves the $\alpha$ parameters:

$\ln Y_{i t}-\ln Y_{i t-1}=a_{1}\left(S_{i t}-S_{i t-1}\right)+a_{2}\left(e_{i t}-e_{i t-1}\right)+a_{3}\left(e_{i t}^{2}-e_{i t-1}^{2}\right)+\left(\varepsilon_{i t}-\varepsilon_{i t-1}\right)$.

One could have instead taken a mean deviation, but the first-difference approach has the advantage of using past exogenous variables as predetermined instruments whereas the mean-deviation does not have this advantage because every lagged exogenous variable is encompassed in $\bar{x}_{i}$. On the other hand, first difference techniques exacerbate measurement errors (Freeman, 1984). See Kim and Polachek (1994) for more detail on these and other techniques as well as statistical tests to determine when such estimates are warranted.

An early study using this (actually the mean-deviation) technique is Brown (1980) who utilized a Mincer-type earnings function to measure equalizing wage differences. The notion of equalizing wage differences argues that workers receive compensating wage premiums when they work at jobs with undesirable attributes. Common examples are combat pay for soldiers or higher wages for nighttime duty, but one can also view the returns to schooling as a form of compensating wage differences. Here the market 
compensates workers for having to forego earnings to attend school sometimes for many years. By and large, with the exception of human capital type variables, previous research yielded inconsistent estimates of compensating wage differences. According to Brown, failing to account for important unmeasured individual characteristics was an often cited reason for these inconsistencies, which is what lead him to adopt panel data techniques to estimate earnings functions.

Errors-in-measurement is one problem to be wary of when using the firstdifference technique. According to Freeman (1984) modest errors in independent variables can bias coefficient estimates downward. The reason is two-fold. First, a given number of random errors in any one time period yields additional errors when these erroneous data points are used to compute first-differences in conjunction with accurate data from adjacent time periods. Second, a small error in the level of a variable can become a large error in the change of a variable. Such errors bias coefficients downward and increase coefficient standard errors. Standard error-in-measurement approaches using instrumental variables are often problematic because of the difficulty of identifying appropriate instruments. For this reason, Griliches and Hausman (1986) suggest methods to transform the data in a way that sometimes can identify the errors without the need for external instruments. Alternatively, Polachek and McCutcheon (1983) and Polachek, Wunnava and Hutchins (1987) use data which can be cross-checked to get around errorsof-measurement. On the other hand, Bound and Krueger (1991) show that longitudinal data may be more reliable than one might suspect if measurement errors are serially correlated across years.

Models adjusting for unmeasured heterogeneity usually assume that all individual-specific differences affect only the intercept. In a Mincer earnings function regression, this means individual-specific initial earnings levels. However, it is quite possible that unobserved individual-specific characteristics, most especially ability, affect earnings function slopes. The problem is that this assumption of common earnings function gradients need not square with human capital theory. As described earlier in Section III, human capital creation is governed by the production function 
$Q(t)=f[s(t) K(t)]$. Taking a simple Cobb-Douglas as an example, $Q=[s(t) K(t)]^{\beta}$ implies one's capability to create human capital is greater the higher the $\beta$. This ability (measured by $\beta$ ) decreases the marginal cost of creating human capital. As a result higher $\beta$ values increase the amount of human capital created, per unit of time invested. For the more able, this translates to both higher and steeper earnings profiles. Polachek and Kim (1994) develop a tractable panel data approach to estimate models containing individualspecific intercept and slope parameters.

\section{Extending the Human Capital Model}

Adding categorical dummy variables to the basic Mincer earnings function yields estimates of earnings differences across each category. As such, the Mincer earnings function has been modified to incorporate region, union membership status, city size, race, gender, ethnicity, migration status, health status, tenure on the job, and a host of other factors that could affect earnings.

Many define wage differences among race and gender holding education and experience constant to constitute discrimination. As an illustration, Kamalich and Polachek (1982) fit a modified Mincer earnings function using 1976 Panel Study of Income Dynamics (PSID) data replicated in Table 5 they fit earnings functions for the entire population, as well as within racial (white and black) and gender groups. They find about a 35\% gender wage gap (37\% for whites and $29 \%$ for blacks) and a $13 \%$ blackwhite wage gap ( $18 \%$ for males and $4.3 \%$ for females). However, the human capital can be used to explain these demographic wage differences. In what follows, I first examine race, then gender.

\section{A. School Inputs and Earnings: Race, Education and Black-White Earnings Differences}

Prior to 'Brown vs. the Board of Education,' blacks in the U.S. were relegated to separate but 'equal' schools. Welch (1974) argued that at least a portion of the black- 
white earnings gap is attributable to black school quality deficiencies. Using data from several age groups, he shows dramatic increases in educational rates of return to 'newer' vintage black cohorts. Welch attributes these greater schooling returns to increases in black school quality relative to whites. He proceeds to make a case that school quality is an important aspect of the black-white earnings gap. Despite its persuasiveness, the Welch study is limited because it contained no direct measures of per capita inputs for black compared to white schools. By going back to state data, Card and Krueger (1992) rectified this deficiency by comparing direct measures of school quality. These include pupil-teacher ratios, annual teacher pay, and length of school term, all of which are linked to U.S. Census data. Changes in school quality explain at least $50-80 \%$ of the relative increase in black educational rates of return and at least $15-25 \%$ of the narrowing of the black white earnings gap between 1960 and 1980. To buttress these results, Ashenfelter, Collins and Yoon (2005) identify Southern individuals born in the 1920s and 1930s from 1970 Census data to find that racial disparities in measurable school characteristics had a substantial influence on black males' earnings. They go on to show "that southern-born blacks who finished their schooling just before effective desegregation occurred in the South fared poorly compared to southern-born blacks who followed behind them in school by just a few years.” In addition, Card and Lemieux (1996) use changes in rates of return to explain black-white differences over the 1980s. While some might offer explanations other than human capital, there is a striking consistency with human capital predictions: education positively enhances labor market success, and better schools do the same so that at least part of the black-white wage gap can be attributed to race differences in schooling quality. ${ }^{18}$

\section{B. Earnings of Women ${ }^{19}$}

\footnotetext{
${ }^{18}$ One should note contrasting views on school quality. For example Eric Hanushek (1996) states that specific educational programs are not consistently related to student performance. On the other hand, John Kain and Steven Rivkin (2002) find that special education boosts mathematics achievement for learning disabled students. However, how these educational achievements translate into market success requires further study, according to Hanushek, Heckman and Neal (2002).

${ }^{19}$ See Hirsch (2006) for a more complete survey of the literature examining the sources of the gender pay gap.
} 
In 1960 the male-female wage gap (adjusting for education and potential experience) was about 43\%. By 2005, the male-female wage gap (again adjusted for education and potential experience) declined to $24 \%$. Indeed, with the exception of about 1940 to 1980, the wage gap has been steadily declining at least since the late 1800s (Polachek, 2006). This leads to two questions: (1) Why is there a male female wage gap? And (2) why has the gap been declining?

Before answering these questions, I apply the Mincer earnings function to estimate the gender wage gap and present evidence in Table 6. The reported results are Mincer earnings functions augmented with a gender categorical dummy variable using United States data between 1940 and 2005. The gender coefficients indicate the malefemale wage differential holding constant measured schooling and potential experience. These coefficients conform to the numbers just given above of a $20-43 \%$ earnings difference between men and women. Often additional variables such as race, occupation, industry, and other socioeconomic variables are added as independent regressors. Some take this estimate of the wage gap to reflect discrimination because it measures the female wage shortfall, holding constant school and experience and other variables affecting labor market productivity. Others are skeptical that this coefficient measures discrimination, more on this later.

By now hundreds of studies adopt this type approach to measure the gender wage gap. Rather than examine each study one-by-one Weichselbaumer and Winter-Ebmer (2003) perform a meta-analysis of the "unexplained" gender wage gap across 238 separate studies. In their analysis they regress the estimated male-female wage gap obtained from each of the 238 studies against such independent variables as characteristics of each study's data (for example, whether the data contain actual work experience or potential work experience measured simply as the chronological time between the survey and the year one finished school), the estimation method used in each study, the variables used in each study, the specific country characteristics pertaining to each study, as well the characteristics of each study's authors (for example, whether they 
were male or female). Their results indicate that using potential instead of actual experience, has the biggest impact on the calculated gender wage gap.

To see why, consider one set of studies that interacts gender, martial status and family characteristics (Polachek, 1975b and Harkness and Waldfogel, 2003). Essentially, these studies run the regression:

$\ln Y_{i}(t)=a_{0}+a_{1} S_{i}+a_{2} t_{i}+a_{3} t_{i}^{2}+\alpha_{5} F_{i}+\alpha_{6} M_{i}+\alpha_{7} F * M_{i}+\alpha_{8} C_{i}+\alpha_{9} F^{*} C_{i}+\alpha_{10} F^{*} M * C_{i}+\alpha_{11} X_{i}+\varepsilon_{i}$

where $\ln (\mathrm{Y})$ is the logarithm of earnings, $\mathrm{S}$ represents years of schooling, $\mathrm{t}$ and $\mathrm{t}^{2}$ depict years of experience and its square, as have already been defined; and $\mathrm{F}$ is a categorical gender dummy variable for being female, $\mathrm{M}$ a categorical dummy variable for marital status, $\mathrm{F}^{*} \mathrm{M}$ an interaction term between gender and marital status, $\mathrm{C}$ the number of children, $\mathrm{F} * \mathrm{C}$ and interaction term between gender and number of children, $\mathrm{F}^{*} \mathrm{M} * \mathrm{C}$ a three-way interaction term, $\mathrm{X}$ other relevant exogenous variables, and $\varepsilon_{i}$ a random error term for each individual observation. This specification yields estimates of the gender wage gap for married men and women separately from single men and women. It also estimates the effect of children on the gender wage gap. The interesting result is a "family wage gap" in which the gender difference in wages is relatively small for single men and single women, yet large for married men and married women, and especially large for those married men and women with children. (The gap is even larger still between men and women in families where the greater the number of years spacing from oldest to youngest child.) Table 7 reflects the results of the marital status differential by presenting international evidence using the Luxembourg Income Study data. Independent of country or year, the gender gap for singles varies between $20 \%$ in favor of men to $4 \%$ in favor of women (the unweighted average is about $8 \%$ in favor of single men over single women) to between 3 and 56\% (with an unweighted average of about 30\%) for married men and over married women. 
Corporate discrimination cannot explain these wage patterns. Were corporate discrimination the reason, one would need an explanation why corporations hardly discriminate against single women, but discriminate enormously against married women, especially married women with children spaced widely apart, given that they often cannot legally ask questions about marital status in employment applications. Even if they could get this marital status information, they wouldn't have information on the number and spacing of one's children. But even if supervisors knew number of children, they are far less knowledgeable about children's ages, and hence less likely to know much about child spacing.

Statistical discrimination models are equally weak. Advocates of statistical discrimination argue that corporate hiring and promotion are based on corporate expectations that women drop out of work frequently to fulfill family responsibilities. As such, corporations hire women in the more menial jobs and refuse to provide them with training. At best, there is only mixed evidence for statistical discrimination. Audit studies analyze firm hiring practices by sending "pseudo" job seeking males and females with similar job résumés to respond to want ads (Greenacre and Blasius, 1994). One problem is that audit studies neglect supply-side considerations (Nelson and Polachek, 1995). ${ }^{20}$ If a firm finds it costly to offer a job that is refused, the prudent employer will tend to offer jobs only to discernable groups that have a high probability of accepting the offer. Despite this, whereas several audit studies find gender differences (Mellor and Paulin, 1995, Neumark, 1996), the very latest most comprehensive analysis (Bertrand and Mullainathan, 2004) finds no gender difference in employers' proclivity to call back job applicants for an interview. But even were corporations to discriminate in hiring and pay practices, women would counter by beginning their own businesses. However, we see little evidence of women initiating new business more frequently than men. Nor is there evidence that female-owned businesses hire more women than male-owned businesses. The 1992 U.S. Bureau of Census Characteristics of Business Owners Survey indicates a smaller proportion of businesses owned by women (especially among older women

\footnotetext{
${ }^{20}$ Heckman and Siegelman (1993) and Heckman (1998) raise other more technical pitfalls of the approach.
} 
where discrimination is likely to be greatest) and fewer women employed in female owned businesses. See http://www.census.gov/csd/cbo/1992/www/cbo9201.htm.

Consistent with the above arguments, one should also note that government policies aimed directly at corporate discrimination have not alleviated the gender wage gap. In the 1990s the number of class actions lawsuits rose from 30 in 1992 to 68 in 1996, and the number of job bias lawsuits increased from 6,936 in 1990 to 21,540 in 1998 (Blau, Ferber, and Winkler, 2002:243), but the rate of gender wage convergence slowed in the late 1990s. From 1980 to 1981, despite the fact that the Office of Federal Compliance dropped its budget from \$48.2 million to \$43.1 million (Smith and Welch, 1984), female wages grew $1.7 \%$ per annum faster than male wages in the 1980 s than the 1970s. In the 1970s, enforcement of anti-discrimination laws increased 20-fold. For example, Smith and Welch (1984: 273) indicate that in 1970 only 340 Title VII cases were filed in Federal Courts, whereas in 19816250 cases were filed, though one should note that a number of these cases refer to race discrimination. Nevertheless, in the 1970s compared to the 1980 s, female wages grew at a rate only $0.39 \%$ per year faster than male wages, resulting in very little narrowing of the gender wage gap (Polachek and Robst, 2001). In a six country comparison of affirmative action, Jain et al (2003) find mixed results of affirmative action type programs and conclude that "there is no universal panacea ... for resolving the employment problems of disadvantaged groups. ... Cultural constraints ... have an impact on the success of the programs (Jain, Sloane, and Horwitz, 2003:214)". This is confirmed in Blau, Ferber and Winkler (2002: 242) who state "a review of the trends in the male-female pay gap ... gave no indication of a notable improvement in women's economic status ... that might be attributable to the effects of the government's antidiscrimination effort, at least through the late 1970s or early 1980s." Clearly something other than corporate discrimination must be at work.

Marital status and family are related to lifetime labor force participation. Figure 8 depicts gender-marital status labor force participation patterns for the United States in 1970 and 2004. On the horizontal axis is age. On the vertical axis are labor force participations rates. These rates indicate the proportion of each gender-marital status 
group in the labor force. Beginning with 1970, married men have the highest lifetime labor force participation. Married (spouse present) women have the lowest, peaking at about $43 \%$ between the ages of 23 and 48 . The drop around age 30 reflects intermittent labor force participation related to childbearing. The gap between single males and females is the narrowest. Single never-married men and women have roughly the same lifetime work patterns. By 2004, the differences are appreciably smaller. The biggest change is the extent married female labor force participation rose over the three decades. However, even in 2004, married women participate between 1/4 and 1/3 less than married men. Again in 2004, the labor force participation gap is miniscule for singles.

Retrospective work history surveys as well as panel data convey similar information from a different perspective. Retrospective work history data ask respondents about their past work patterns. Panel data follow respondents through time. ${ }^{21}$ While less stark, the same lifetime work patterns emerge from retrospective data. Using the 1980 Panel Study of Income Dynamics Data (PSID) Miller (1993) finds that married women average 10.04 years out of the labor force. Similarly, using a panel of 2659 individuals from the 1976-1987 PSID data, Polachek and Kim (1994) find that women averaged 9.62 years out of the labor force relative to men's 2.22 years. Current data for foreign countries are comparable. Using Canadian data, Simpson (2000) finds that in 1993 married women with children averaged 7.6 years (or 36.4\% of their work years) out of the labor force, whereas single women spent 1.5 (or 12.9\%) of their work years out of the labor force. For men, this figure is 0.9 years (or 8.1\%). Data within narrow professions yield similar results. Catalyst (2003) finds that only $29 \%$ of women MBA graduates work full time continuously since graduation compared to $69 \%$ for men, and similarly only $35 \%$ of women law graduates worked continuously since graduation compared to $61 \%$ for men.

\footnotetext{
${ }^{21}$ Synthetic cohorts comprise putting together cross-sectional data from year-to-year without following specific individuals over time. Given that synthetic cohorts compound cohort (generational) and lifecycle (aging) effects, one can argue that retrospective and panel data are superior.
} 
Mincer and Polachek (1974) modify earnings function (4) to incorporate exogenous discontinuous labor force participation. ${ }^{22}$ Recall that at any point in one's life, one's potential earnings are related to the stock of one's accumulated human capital investment. Equation (11) in the section deriving the Mincer earnings function specifies these earnings as:

$$
\ln E_{t}=\ln E_{0}+r_{s} S+r_{p} \sum_{i=0}^{t-1} k_{i}=\ln E_{0}+r_{s} S+r_{p} \int_{0}^{t} k(j) d j
$$

To adopt (11) to incorporate intermittent work behavior, one need only break up the postschool investment term $\mathrm{k}(\mathrm{j})$ into segments of participation and nonparticipation to reflect the differing levels of human capital investment that occur chronologically in each work/non-work segment. One can assume a linear human capital investment function of the form $k(t)=a_{i}+b_{i} t$ where $\mathrm{a}_{\mathrm{i}}$ is the initial "time-equivalent" investment and $\mathrm{b}_{\mathrm{i}}$ is the rate of change in investment taking place in of the $n$ work/non-work segments i. This yields an earnings function

$$
\ln E_{t}=\ln E_{0}+r_{s} S+r_{p} \sum_{i=1}^{n} \int_{0}^{e_{i}}\left(a_{i}+b_{i} t\right) d t
$$

For the three period case where $\mathrm{n}=3$ (for example, when one works just after finishing school, then drops out perhaps to bear and raise children, and finally reenters the labor market), the earnings function is a quadratic in each work/non-work segment:

$$
\ln E_{t}=\ln E_{0}+r_{s} S+r_{p}\left(a_{1} e_{1}+\frac{1}{2} b_{1} e_{1}^{2}+a_{2} e_{2}+\frac{1}{2} b_{2} e_{2}^{2}+a_{3} e_{3}+\frac{1}{2} b_{3} e_{3}^{2}\right)
$$

Taking a linear approximation of the quadratic in each segment and denoting segment $\mathrm{e}_{2}$ as $\mathrm{h}$ (since it represents time at home out of the labor force) yields:

\footnotetext{
${ }^{22}$ In empirical work Mincer and Polachek (1978) adjust for endogenous lifetime work using two-stage least-squares estimation. Also see Gronau (1988).
} 


$$
\ln E_{t}=\ln E_{0}+r_{s} S+r_{p}\left(a_{1} e_{1}+a_{2} h+a_{3} e_{3}\right)
$$

Finally, taking account of the distinction between potential and observed earnings spelled out in equation (14) yields

$$
\ln Y_{t}=\ln E_{0}+r_{s} S+r_{p}\left(a_{1} e_{1}+a_{2} h+a_{3} e_{3}\right)+\ln (1-k(t))
$$

where $t=e_{1}+h+e_{3}$. With $k(t)$ relatively small, given that it depicts a time late in life, so the same estimating equation holds when estimating $\ln \mathrm{Y}_{\mathrm{t}}$ as it does for $\ln \mathrm{E}_{\mathrm{t}}$, only the interpretation of the intercept $\mathrm{a}_{0}$ is affected:

$$
\ln Y_{t}=a_{0}+r_{s} S+\alpha_{1} e_{1}+\delta h+\alpha_{2} e_{3}
$$

Figure 9 illustrates graphically how (41) is typically implemented. The point $\mathrm{O}$ reflects the year a wage earner graduates from school. After graduation, the wage earner enters the labor force for $\mathrm{e}_{1}$ years. Following this, the wage earner drops out for $\mathrm{H}$ years perhaps to bear and raise children. The period $\mathrm{e}_{2}$ represents years worked after reentry in the labor force. In 1967 the value of $\mathrm{H}$ was just over ten years. In the 1985 National Longitudinal Survey, H was between 9 and 14 years (Sorensen, 1993). For men H is less than one-and-a-half years (Kim and Polachek, 1994).

A continuous worker's earnings profile is $O^{\prime \prime} K H$. It illustrates that earnings rise (but at a diminishing rate) throughout the continuous worker's lifetime, possibly tapering off and even declining close to retirement. The intermittent workers exhibit a different earnings profile (OABF). First, initial earnings are lower (point O). Second, the slope of the earnings profile $\left(\alpha_{1}\right)$ is initially smaller, rising to A. Third, earnings are essentially zero during the "home-time" period $(\mathrm{H})$, but earnings potential (were one to work) diminishes by an "atrophy" rate $\delta \%$ per year out of the workforce. Fourth, the reentry wage after dropping out is lower than when one left ( $\mathrm{B}$ is lower than $\mathrm{A}$ in real terms). 
Finally, after reentering the labor force, earnings grow at a rate $\alpha_{2}$ (which is slightly higher in magnitude than $\alpha_{1}$ ) from B to F.

The $\alpha_{1}$ and $\alpha_{2}$ coefficients range from $1.2 \%$ to $4.0 \%$, depending on the population subgroup studied and on one's level of education. The $\delta$ coefficient ranges from $-4.5 \%$ to $-0.5 \%$ depending on the respondent's amount and type education. In general, the higher one's education and the more skilled one's job, the greater the magnitude of these coefficients. Also, $\alpha_{2}$ often exceeds $\alpha_{1}$ because upon reentering the labor one has a greater commitment to working more continuously (Polachek, 1975 and Weiss and Gronau, 1981). By now, numerous studies adopted this approach to assess the effect of work interruptions. Examples include Albrecht et al., 1999; Baum, 2002; Corcoran and Duncan, 1979; Corcoran et al., 1983; Hotchkiss and Pitts, 2003, 2005; Jacobsen and Levin, 1995; Kim and Polachek, 1994; Light and Ureta, 1990, 1995; Mincer and Ofek, 1982; Mincer and Polachek, 1974; Phipps, Burton and Lethbridge, 2001; Rummery, 1992; Sandell and Shapiro, 1980; Sen, 2001; Stafford and Sundstrom, 1996; Stratton, 1995.

As already illustrated, the life-cycle human capital model links expected lifetime labor force participation to one's incentive to make marketable human capital investments. The lower the expected lifetime work, the smaller the gains from human capital investment, the lower the amount invested, and finally the lower one's wage. More importantly, a worker who anticipates discontinuous labor force participation acquires on-the-job training at a different rate than the continuously employed worker (Polachek, 1975a and Weiss and Gronau, 1981). Rather than begin one's work-life with large but diminishing amounts of training, the discontinuously employed worker initially obtains little training, but the amount of training rises moderately after the worker permanently reenters the workforce. For women, this usually occurs when childbearing is complete. As a result, women's earnings need not exhibit the usual concave age-earnings profiles characteristic of men. Instead, they are flatter and often exhibit a non-monotonic pattern (that is they exhibit a midlife dip) depending on the degree of intermittent work behavior (Mincer and Polachek, 1974). 
To see this analytically modify the lifecycle optimization model spelled out in equations (1) to (3) above by introducing the possibility that labor force participation can vary year-by-year over the lifecycle (Polachek, 1975a). As such, modify (1) so that

$$
Y(t)=[N(t)-s(t)] w K(t)
$$

where $\mathrm{N}(\mathrm{t})$ is the proportion of time available spent working in the labor force and investing in human capital. Assume $\mathrm{N}(\mathrm{t})$ is exogenous to the investment process, but dependent on gender, marital status and the number of children. Embedding (42) in (1) and maximizing subject to the same constraints as before implies that investment levels are now dependent on lifetime labor force participation. The higher the level of $\mathrm{N}(\mathrm{t})$ the more human capital one purchases.

Now allow for intermittent labor force participation. As such $\mathrm{N}(\mathrm{t})$ is not constant in each period. This yields the following marginal gain from investment:

$$
\dot{\psi}=-w_{0} N(t) e^{r(t-T)}+w_{0} r e^{r t} \int_{t}^{T}[N(\tau)-N(t)] e^{-r \tau} d \tau
$$

The first term represent the marginal revenue if labor force participation were constant each time period. It is negative and identical to Ben-Porath's declining marginal gain from investment over the lifecycle. The second term represents the incremental change to marginal revenue when labor force participation is not constant over the lifecycle. This term is positive if future labor force participation is expected to rise, as in the case when a woman anticipates reentering the labor force after raising her children. A sufficiently large second term implies an increasing present value of human capital investment. This means that intermittent labor force participation can cause human capital investment to rise during and after one's childrearing years instead of falling monotonically as BenPorath predicted. As such, post-school human capital investment (on-the-job training) crucially depends on expected lifetime labor force participation. 
Figure 10 illustrates these human capital investment patterns. The left side of the diagram replicates the Ben-Porath model for continuous workers. The right side modifies the typical Ben-Porath model by showing how lifecycle human capital investment differs for the discontinuous worker. For the continuous (usually male) worker, the present value of the marginal gain from investment (denoted in the graph as $\lambda_{t}$, but not to be confused with the inverse Mills ratio used earlier when discussing selectivity) declines monotonically with age (t). By contrast, the present value of the marginal gain from a unit of investment is initially lower (both because of the anticipated time out of the labor market and the fewer hours of work per week) and need not decline monotonically for the discontinuous (often the female) worker. This implies discontinuous workers not only invest less over their lifetime, but also their investment need not monotonically decline. Given that earnings are directly proportional to accumulated human capital, continuous workers exhibit a concave earnings profile. In contrast, discontinuous workers can have convex regions within their age-earnings profile.

Current studies decomposing the gender wage gap grossly underestimate the explanatory power of the human capital model because of their failure to account for future expected lifetime labor force participation. To see this, go back to Figure 9 and compare men's (assumed to be the continuous workers) earnings to what women (assumed to be the intermittent workers) would earn if women worked continuously.

The total gap in earnings between the continuously working (male) and a intermittent female worker reentering the labor market after dropping out $\mathrm{H}$ years can be expressed as segment BK. This is the difference between the man's wage $(\mathrm{K})$ and the intermittent worker's reentry wage (B). This gap can be divided into three segments: (1) BC - the direct depreciation of skills caused by atrophy. Distance BC amounts to product of the number of years out of the labor force $(\mathrm{H})$ and the per year depreciation of earnings power measured by atrophy rate $\delta$. (2) CD - the foregone wage growth caused by lost seniority, assuming one's earnings rise from A at rate $\alpha_{1}$. And, (3) DK - the earnings gap a male’s earnings and the earnings a female would have, should she work continuously. 
The standard decomposition approach depicts discrimination by the distance DK. DK measures the male-female earnings gap, assuming women have men's labor market characteristics (such as, worked as many years as men $\left.\left(e_{1}+H\right)\right)^{23}$ The problem, however, is that DK overstates the amount of discrimination. To see this, decompose DK into three parts: DG, GN, and NK. The gap DG reflects the additional earnings growth ( $\alpha_{2}$ per annum compared to $\alpha_{1}$ ) a woman would get from extra on-the-job training if she expected greater labor market continuity. The gap GN reflects additional earnings levels coming about from more market-oriented schooling one would obtain where one to be in the labor market a greater number of years. The remainder NK better represents the unexplained gender wage differential attributable to discrimination. It accounts for the extra human capital investments a woman would make if she expected to work more years over their lifetime. Failing to take account of how female earnings projections change when lifetime work expectations increase biases upward most current estimates of discrimination, measured as DK.

Incidentally, another defect inherent in this type decomposition is it fails to attribute lower female lifetime work to discrimination. It attempts to take account of work differences rather than consider the possibility that these differences come about because of discriminatory societal forces such as tax laws unfavorable to women, the unavailability of day care, or even guidance counselors that advise female students against market oriented fields of study. As such, male and female differences in work history (as well as other differences) also constitute discrimination. Yet the decomposition approach does not treat these lifetime labor market differences as comprising discrimination. Neglecting these societal forces leads the decomposition approach to underestimate discrimination.

\footnotetext{
${ }^{23}$ Studies without work history information aggregate $\mathrm{e}_{1}$ and $\mathrm{H}$ to obtain e equal to $\mathrm{e}_{1}+\mathrm{H}$. This biases downward the $\mathrm{e}_{1}$ coefficient thereby leading to even lower projected female earnings, than $\mathrm{D}$. As will be apparent, this erroneous specification severely overestimates discrimination. See Mincer and Polachek (1974).
} 
These arguments can be made more formally. Typically DK is estimated from a regression model. Female earnings $D$ are estimated from earnings function $y=f_{F}\left(x_{F}\right)$, in which $y=\ln y$, and $\mathrm{x}$ is a vector of worker characteristics including $\mathrm{e}_{1}, \mathrm{H}$ and $\mathrm{e}_{2}$, as well as other worker attributes such as industry, occupation, race, union status, and more. The $\mathrm{F}$ subscript in $f$ indicates that the earnings function is estimated with data on females. Male values for $\mathrm{x}$ are denoted by $\mathrm{x}_{\mathrm{M}}$. Female values are denoted as $\mathrm{x}_{\mathrm{F}}$. The value $y_{F}=f_{F}\left(x_{M}\right)$ equals projected female earnings, were women to have the same characteristics as males (that is, zero $\mathrm{H}$ ). It is comparable to $\mathrm{N}$ in Figure 7. Male earnings (K) are estimated by $y_{M}=f_{M}\left(x_{M}\right)$. The difference D-K represents discrimination - the gap in earnings between what males make and what females should make if they had male characteristics. This measure is often called the "Blinder-Oaxaca" decomposition because Alan Blinder (1973) and Ronald Oaxaca (1973) were the first to apply this type decomposition to gender differences in wages. However, the problem is that this decomposition approach is marred by bias. To see the problem, note that the measure assumes that discrimination is defined by differences in male and female earnings functions because $K-N=y_{M}-y_{F}=f_{M}\left(x_{M}\right)-f_{F}\left(x_{M}\right)$. This means that male-female differences in characteristics $\left(x_{M}-x_{F}\right)$ are deemed legitimate reasons for gender earnings differences, whereas male-female differences in earnings structure $\left(f_{M}-f_{F}\right)$ constitute discrimination. As mentioned above, discrimination is overestimated if $f_{M}$ differs from $f_{F}$ for legitimate reasons, for example that human capital theory predicts $f_{M}$ to be steeper than $f_{F}$ when female lifetime work expectations are less than male lifetime work expectations. Discrimination is underestimated when $\mathrm{x}_{\mathrm{M}}$ and $\mathrm{x}_{\mathrm{F}}$ differ because of discrimination.

One set of studies accounts for these biases. Polachek (1975a), Golden and Polachek (1987) and Kao et. al. (1994) analyze wage differences for the US and for Taiwan. These results summarized in Table 8 illustrate that whereas between 30 and 48 percent of the gender wage gap is explained by schooling and potential experience, between 63 and 93 percent is explained when incorporating estimates of expected lifetime labor force participation. To illustrate the robustness of the procedure (not shown in 
Table 8), these studies also explained a large portion of the marital status wage gap within genders (more specifically, they explained 82 percent of the wage gap between single and married males as well as 76 percent of the wage gap between single and married females). Thus the human capital investment process, more specifically how gender differences in lifetime work affect human capital acquisition, can explain why there is a gender wage gap, as posed by the first question above.

Similarly, changes in lifetime labor force participation can answer the second question, why the gender wage gap narrowed. At least since the time data has been

collected, women's, especially married women's, labor force participation has risen. In 1890, only 4.9\% of America's married women participated in active work for pay in the labor market (Figure 11); in 2001 this figure was 61.4\%. Higher labor force participation raises expected lifetime work and as a result increases human capital investments and wages. At the same time male labor force participation (not shown in Figure 11) declined moderately. As such, female human capital investments most likely rose relative to males’ human capital investments, thereby resulting in a higher female-to-male wage ratio. This is precisely what is observed in Figure 11. However, there are exceptions, such as between 1940 and 1950 and 1960 and 1975. Polachek and Robst (2001:869) found that the rapid rise in "new female labor force entrants in the 1970s brought down mean female wages, thereby driving down female wage growth." This is probably the case for the 1940s, as well, which witnessed an unprecedented influx of women workers during World War II.

\section{Heterogeneous Human Capital, Matching and Occupational Distribution}

It is well known that men and women have different occupational structures. Although women comprise about $46 \%$ of the US labor force, only $9.9 \%$ of engineers are women. In contrast nursing is $92.8 \%$ female. This difference in occupational structure is called occupational segregation. The Council of Economic Advisers (1998) illustrates this occupational segregation using Figure 12. They find that between 1983 and 1997 the 
proportion of women in managerial and professional occupations increased from 23 to 32 percent, while for men the proportion rose only from 26 to 29 percent. On the other hand, women compared to men are more likely to work in service and clerical jobs, while men are more likely to be in blue collar (craft, operator, and laborer) jobs.

Others (mostly sociologists) use the Duncan index of occupational dissimilarity to describe the degree of occupational segregation. This index measures the proportion of women that would have to change their occupation to make the distribution of occupations the same for each gender. ${ }^{24}$ In an index based on 29 occupational categories Albelda (1986) shows that occupational segregation decreased from 60.3 in 1958 to 53.0 in 1981. Using 159 occupations, King (1992) reported the magnitude of Duncan's index based on Census data for 1940, 1950, 1960, 1970, and 1980 decreased from 0.8 to 0.6. A more recent study (Ruel, 2004) finds similar results using a multiplicative model developed by Charles and Grusky (1998).

A natural inclination is to argue that occupational segregation and the gender wage gap are related. One theory of gender wage differences known as the "crowding hypothesis,” with roots at least as far back as Edgeworth (1922) and Rathbone (1917) but popularized by Bergmann (1974), argues that certain occupations are "set aside" for women, but men are free to choose their occupation of choice. The result is that women are relegated to more menial occupations, increasing the number of workers (especially women) supplied to these jobs and thus depressing female pay. In turn, the supply to “male” occupations decreases causing men’s wages to rise.

Two approaches have been used to test the crowding hypothesis. One method computes an index measuring the proportion of the gender wage gap explained by occupational segregation. To do this, one calculates how much the gender wage gap changes if females were assigned the male occupational distribution instead of their own.

\footnotetext{
${ }^{24}$ The formula is: $\frac{1}{2} \sum_{i=1}^{n}\left|m_{i} f_{i}\right|$ where I indexes each of the n occupations, and $m_{i}$ and $f_{i}$ are the respective number of men and women in each.
} 
(Alternatively, one can compute how much the gender wage gap changes if males were assigned the female occupational distribution instead of their own.) Chiswick et al. (1975) compute such an index. They explain $28 \%$ of the wage gap when using the whole 1970 U.S. Census. Using the same approach, Treiman and Hartmann (1981) explain between 11 and $18 \%$ of the gender earnings differential when using data on 222 U.S. Census occupations and 35-39\% using 495 occupations. On the other hand, when confining themselves to single women and men, occupational segregation has no impact whatsoever. Indeed the wage gap widens. This widening is confirmed by Hwang and Polachek (2005) for US and Korean data.

One problem is that these studies do not hold constant demographic characteristics. As such, they do not take account of human capital or other demographic characteristics. So if men attain higher paying occupations because greater lifetime work led them to invest more, the above studies likely overestimate occupational segregation's importance because lower levels of human capital, rather than discrimination, might instigate women to be in lower paying occupations. For this reason a second set of studies adopt a multivariate framework.

The second approach characterizes an occupation by its proportion of female incumbents. The coefficient on this "proportion female" variable in a Mincer earnings regression (holding other variables constant) indicates how changes in an occupation's proportion female are related to earnings. The greater the importance of occupational segregation the smaller should earnings be. Accordingly, one can predict the impact of occupational segregation by projecting the extent earnings decrease as occupations move from being male to becoming more female. These estimates explain at most $37 \%$, but most likely far less, of the earnings gap. For example, Fuchs (1971) gets an explanatory power of between 0 and 6\%, England (1982) less than 5\%, Johnson and Solon (1986) get an explanatory power of 8 and 19\%, Sorenson (1990) gets an estimate of 20-37\%, while using estimates derived from longitudinal data Gerhart and Cheikh (1991) get an estimate of 1.7\% and MacPherson and Hirsch (1995), in one of the latest and most comprehensive studies, find that occupational segregation explains less than $7 \%$ of the gender wage gap. 
In contrast, as shown above, human capital models explain 45-95\% of the gender wage gap. Nevertheless, by assuming heterogeneous human capital, the lifecycle Ben-Porath model can be adopted to explain gender differences in occupational structure. To do this we modify the human capital model by relaxing the assumption that human capital is homogeneous.

The Dictionary of Occupational Titles and its replacement, the Occupational Information Network, indicate that job skills differ across occupations. Varying skill levels are consistent with what we know about how college majors differ across fields and what we know about how courses taken in high school vary between college preparatory and vocational diplomas (Polachek, 1978; Paglin and Rufolo, 1990). To incorporate this type human capital heterogeneity, one can index type of human capital based on occupational characteristics (Polachek, 1979, 1981) in order to provide a unique mapping of job characteristics into occupations. This approach utilizes the hedonic price model (Court, 1939; Court, 1941; Houthakker, 1951-2) so that earnings are related not only to the amount of human capital but also to the varying rental rates associated with each different type of human capital. Let $\delta$ be a vector of occupational characteristics that can be taken to map directly to specific unique occupations. Unlike occupation, per se, the index composed of continuous variables and hence can serve as a control variable within the lifetime maximization process described earlier.

Including occupational characteristics can be achieved by modifying human capital production function used in (2) and (3) above. More generally assume the time rate of change of human capital is as follows:

$$
\dot{K}(t)=f(s(t), K(t), N(t), \delta(t), \sigma)
$$

where all variables are as previously defined. Embedding (44) into (1) and assuming earnings function (42) that allows for the possibility of discontinuous labor force participation yields a unique vector $\delta$. Simplifying (24) to assume one indexes one's occupation solely by one characteristic, namely the "atrophy" rate which I now denote 
simply as $\delta(t)$, yields a specific version of (45) that Polachek (1979) used in the empirical application

$$
\dot{K}(t)=f(s(t), K(t))-(\sigma+(1-N(t)) \delta(t) K(t))
$$

Note that if $\mathrm{N}(\mathrm{t})=1$, then there is no extra depreciation in the production of human capital from intermittent labor force participation.

Given compensating wage differentials, assume that the rental rate per unit of human capital depends on the atrophy rate. This makes sense because one must be rewarded to take a job with high atrophy. As such,

$$
w=w(\delta(t))
$$

with $w^{\prime}>0$ and $w^{\prime \prime}<0$. If one rules out occupational mobility, the problem simplifies to a two-step maximization. First the individual chooses the optimal $\mathrm{s}(\mathrm{t})$ contingent on $\delta$, then the optimal $\delta$ contingent on the optimal s(t) path. This yields the following result:

$$
\frac{d \delta}{d N(t)}=-\frac{\partial H / \partial N(t)}{\partial H / \partial \delta}>0
$$

where $\mathrm{H}$ is the Hamiltonian. The denominator is positive since it is simply the second order condition from the maximization process. In general the numerator is positive. Thus one chooses a job with a larger atrophy rate $(\delta)$ the more years one works over their lifetime $(\mathrm{N}(\mathrm{t}))$. Conversely, one chooses an occupation with a lower atrophy rate the greater one's time out of the labor market. The intuition is obvious: Atrophy is the cost of discontinuous labor force participation. One chooses the occupation that minimizes the cost of intermittent labor force participation. 
Empirical work generally substantiates this proposition. Utilizing the segmented earnings function enables one to compute atrophy rates by occupation. These empirical results indicate some occupations depreciate more quickly than others when skills are not used. As an example, atrophy rates using a panel data specification ${ }^{25}$ are given in Table 9 . The 45.21 coefficient indicates that hourly earnings depreciate by 45.21 for each year a professional worker is out of the labor force.

These results shed light on occupational segregation. A regression of time out of the labor force and atrophy taking account of the simultaneous relationship between the two yields an inverse correlation. Workers with the greatest timeout gravitate towards occupations with the lowest depreciation. To test the power of this model, Polachek (1981: Table 3) projected how the female occupational distribution would change were women to take no time out of the labor force. The results yielded a $50 \%$ increase of women professionals, a doubling of women in managerial occupations, a 50\% decrease of women in household work, and a $25 \%$ decrease of women in the service sector.

Although initially applied to occupational segregation, this matching framework of linking individual characteristics to job characteristics can be applied to other domains. Polachek and Horvath (1977) examine how individuals match their characteristics (for example, demand for good quality schools) to locational and job attributes to reach conclusions about how the lifecycle human capital models applies to geographic and job mobility. Paglin and Rufolo (1990) show how one's comparative advantage in quantitative versus verbal ability affects one's college major. Jovanovic (1979b) and Jovanovic and Mincer (1981) study how job match quality explains labor market turnover. Booth and Frank (1999) investigate how performance related pay attracts high quality workers. Lochner (2004) illustrates how opportunity costs affect occupation. In his model human capital increases the foregone costs associated with foregone work while incarcerated educated adults leading to the widely observed implication that the

\footnotetext{
${ }^{25}$ The specification is $\Delta W=\alpha_{0}+\alpha_{1} S+\alpha_{2} H+\alpha_{3} X+\varepsilon$ where $\Delta W=$ wage $_{1972}-$ wage $_{1967}, \mathrm{~S}=$ years of school, $\mathrm{h}=$ years out of the labor force, and $\mathrm{X}$ is a vector of standardizing variables.
} 
educated commit fewer street (unskilled) crimes. Gary Becker (1974) considers assortive mating and its concomitant implications regarding family investments in human capital.

On the other hand, some predictions of job matching and human capital differ. For example, Parent (2002) argues that job matching theory forecasts a decrease in the job-match component in the residual variance estimated from a typical Mincer earnings equation using methods of moments techniques as workers acquire tenure on the job. But this prediction is only mildly supported by the data compared to the human capital model prediction of a trade-off between the job-specific intercept and slope parameters of earnings functions run by occupation.

\section{Incomplete Information}

Arguably matching is a form of search. Workers search for the highest paying firms and employers for the employees willing to work at the lowest wages (holding skills and job requirements constant). Whereas search and matching models developed independently of human capital theory (Stigler 1961; Nelson, 1970), they are both related because employees and employers invest in information about each other. Because search is costly neither side can attain full information. Instead efficient search entails employees and employers to adopt stopping rules that lead to sufficing instead of searching until the bitter end. This implies incomplete information for both employers and employees.

Incomplete information manifests itself by the existence of wage dispersion. Were there a full-information perfectly competitive labor market, wages for a given quality of workers would degenerate to a single wage reflecting the competitive wage rate. Incomplete information concerning what each firm is willing to pay (the firm's reservation wage) and incomplete information concerning the minimum wage a worker is willing to take (the worker's reservation wage) yields a compensation structure deviating from this unique equilibrium, even when worker quality is known. Instead, there is a 
distribution of wages. This distribution becomes wider the higher the search costs, and the distribution becomes wider when employee and employer quality are unknown, as well.

A small but growing body of literature is empirical. This literature relies on the overall market-wide price variation to measure the degree of incomplete information (for example, Stigler (1961) Stigler and Kindahl (1970), and Sorensen (2000)). Here, one can infer more incomplete information the higher the variation in wages or prices. As recognized by Stigler and others, a major drawback of using price (or wage) dispersion as a measure of incomplete information is that price and wage dispersion can vary for many reasons other than incomplete information. These reasons include differences in worker quality or simply noisy data. Dispersion measures do not take account of such explanations and thus do not reflect a pure measure of incomplete information. As a result, statistics like wage or price variance simply do not account either for measurable worker differences or random measurement errors.

One technique to get at incomplete information that can disentangle worker quality from pure measurement error is given in Hofler and Polachek (1985) and Polachek and Yoon (1987). The former article estimates employee incomplete information while the latter estimates both employee as well as employer incomplete information. The technique, which is relatively simple to implement, obtains worker and firm incomplete information as parameters obtained from a Mincer earnings function (4), but estimated using frontier estimation techniques. The estimation equation is as follows:

$$
\ln Y_{i}(t)=a_{0}+a_{1} S_{i}+a_{2} t_{i}+a_{3} t_{i}^{2}+u_{i}+v_{i}+w_{i}
$$

where $\varepsilon_{i}=u_{i}+v_{i}+w_{i}$ such that $-\infty<u_{i}<\infty,-\infty<v_{i}<0$, and $0<w_{i}<\infty$. The term $v_{i}$ measures the difference between the wage a worker receives and the wage that could have been attained given knowledge of a higher paying firm. It represents worker incomplete information. The term $w_{i}$ measures the difference between the wage a firm 
actually pays and the wage it could have paid had it known each worker's true reservation wage. As such, it represents the firm's incomplete information. The two-sided error component $u_{i}$ depicts the typical error term representing pure noise.

Polachek and Yoon (1987) tested search theory’s implications by computing average $v$ and $w$ for various groups of workers. They used the Panel Study of Income Dynamics (PSID) for the US in 1981, and found smaller $u$ values for workers who received UI benefits before their current job. This finding illustrated the efficiency UI brings to the labor market through enhanced worker search. Similarly, using the January 1983 Current Populations Survey (CPS), Hofler and Murphy (1992: 516) employ this technique to compute the average worker shortfall using the 1983 US Current Population Survey (CPS). They find that workers in areas paying relatively higher unemployment benefits exhibit less incomplete information. Daneshvary et al. (1992) use the technique to get at assimilation of foreign workers in the United States. Groot and Oosterbeek (1994) found that "males have more labor market information than females [which is] probably caused by the greater market attachment of males, which makes the opportunity costs of ignorance [that is, incomplete information] greater for males than females (p. 388)." They also found that "employees in the public sector possess more market information than workers in the private sector ... probably due to the fact that wage policies in the private sector are in general less public knowledge and more individually based (p. 388).” Polachek and Xiang (2006: 35) use Luxembourg Income Study (LIS) data from eleven countries over various years and find that "incomplete information leads workers to receive on average about $30-35 \%$ less pay than they otherwise would have earned, had they information on what each firm paid.” They also find that workers in countries that strongly support unemployment insurance attain wages closer to their potential. According to them, a doubling of UI decreases incomplete information leading to a 5\% higher wage. Finally, by introducing independent direct measures of workers' knowledge of the World of Work, Polachek and Robst (1998) confirm that this generalization of Mincer's earnings function can be used to actually measure incomplete market information. They show that their measures of incomplete information match with 
those independently obtained for a group of workers in the 1966 US National Longitudinal Survey of Young Men (NLSYM).

\section{The Power of the Mincer Earnings Function in Explaining the Earnings Distribution}

Nowadays there is much concern about the widening earnings distribution. ${ }^{26}$ At least since the 1950s, the US and other economies witnessed a tremendous widening of the earnings gap between rich and poor (Goldin and Margo, 1992; Picketty and Saez, 2003). For example, the share of personal income of the top 1\% of Americans rose to about $17 \%$ in 2005 , compared to about $8.2 \%$ in 1980 . Over the same time period, the share of income going to the bottom $80 \%$ of the working population has fallen about seven percentage points. In short, real incomes of the top quintile wage earners in 2004 rose by $63 \%$ compared to 1980 , whereas households in the lowest quintile were making only $2 \%$ more.

Some scholars (but not all scholars, since there is much debate on the issue) argue this widening of the income distribution has good elements. Nahum (2005) finds “positive impact of inequality on growth” using Swedish data from 1960 to 2000. This is backed up by theoretical work of García-Peñalosa and Turnovsky (2005) who show that faster growth is associated with a more unequal contemporaneous income distribution. A wider earnings distribution provides the motivation to invest in innovation which enhances growth (Becker and Murphy, 2007). On the other hand, too great a reward makes the poor relatively worse off.

A number of studies examine the causes of the recently widening US income distribution. Piketty and Saez (2003) argue that decreases in the progressiveness of the US tax structure the 1970s and 1980s was an important factor. Lemieux, Macleod and

\footnotetext{
${ }^{26}$ Another approach to earnings distribution relates to the proportion of individuals deemed to be low income. See Ziliak (2005) for a survey on new developments in measuring poverty and how poverty rates have changed.
} 
Parent (2006) argue that the growing incidence of performance pay in the US (to be discussed later) is a factor. Kosters (2001) argues that government policies regarding immigration and welfare are factors. Cline (2001), using a general equilibrium simulation framework, presents evidence in favor of increased world trade and immigration. Mincer (1993, 1997) argues that increasing rates of return to education indicative of the persistently higher earnings of skilled workers caused by skill-biased technological change is a factor. One manifestation of this is that technologically based changes in demand for human capital caused the more able workers to sort into the more technologically based industries and jobs (Bartel and Sicherman, 1999). However, Lemieux (2006) argues that there is little evidence of increases in the demand due to skill-biased technological change because the magnitude and timing of the growth in residual wage inequality provide little evidence that skill-biased technological change causes an increase in the demand for skill. Instead Lemieux (2006) argues in favor of demographic socioeconomic compositional effects linked to the secular increase in experience and education.

Some, such as Bernanke, ${ }^{27}$ have suggested that education is one way to make the poor better off. However, it is not obvious education has the effect of narrowing the earnings distribution, unless it results in a decrease in the variance of schooling across the population or a decrease in the rate of return. Chiswick and Mincer (1972) explore this question using a version the basic Mincer earnings function model as its basis. They begin with a slightly modified depiction of the standard Mincer earnings equation (4)

$$
\ln Y_{i}(t)=x+a_{1} S_{i}+a_{2}\left(A_{i}-S_{i}-5\right)+a_{3}\left(\ln H_{i}\right)+\varepsilon_{i}
$$

where all variables are as previously defined except that $t$ is now written as age minus years of school minus 5 (A-S-5). In addition, variations in weeks worked $(H)$, which is entered as a logarithm, are accounted for. ( $\mathrm{H}$ is expressed as a logarithm because annual earnings $\mathrm{Y}$ is the product of weekly earnings and weeks worked. Taking the $\log _{\mathrm{e}}$ implies

\footnotetext{
${ }^{27}$ In his remarks before the Greater Omaha Chamber of Commerce, February 6, 2007, Benanke states "policies that boost our national investment in education and training can help reduce inequality." See http://www.keystoneresearch.org/agenda/FRB_Bernake_Speech.pdf.
} 
$\ln Y=\ln W+\ln H$, where $W$ is weekly earnings. Alternatively, $\mathrm{H}$ could describe hours worked and W one's hourly wage, if one had data on hours worked instead of weeks worked.) One merely can take the variance of the Mincer earnings equation (49) to get implications regarding the factors affecting earnings dispersion. Assuming each variable is independent (which some have questioned, for example, Winegarden, 1979), one can invoke Goodman's (1960) theorem that $\operatorname{var}(x y)=\bar{x}^{2} \operatorname{var}(y)+\bar{y}^{2} \operatorname{var}(x)+\operatorname{var}(x) \operatorname{var}(y)$ to yield

$$
\begin{aligned}
& \sigma^{2}(\ln Y)=\left[\left(\bar{\alpha}_{1}-\bar{\alpha}_{2}\right)^{2}+\sigma^{2}\left(\alpha_{1}\right)+\sigma^{2}\left(\alpha_{2}\right)\right] \sigma^{2}(S)+\left[\bar{\alpha}^{2}+\sigma^{2}\left(\alpha_{2}\right)\right] \sigma^{2}(A)+\alpha_{3} \sigma^{2}(\ln H) \\
& \left.+2 \alpha_{1}\left(\bar{\alpha}_{1}-\bar{\alpha}_{2}\right)-\sigma^{2}\left(\alpha_{2}\right)\right] R_{A S} \sigma(A) \sigma(S)+\left[2 \alpha_{3}\left(\bar{\alpha}_{1}-\bar{\alpha}_{2}\right)\right] R_{S H} \sigma(A) \sigma(\ln H)+2 \alpha_{3} \alpha_{2} R_{A H} \sigma(A) \sigma(\ln H) \\
& +2 \alpha_{2} \alpha_{3} \bar{S}^{2}+[A-S-5]^{2} \sigma^{2}\left(\alpha_{3}\right)+\sigma^{2}(\varepsilon)
\end{aligned}
$$

Differentiating (50) with respect to key variables indicates the effect of these variables on the relative earnings distribution (measured in terms of the $\log _{\mathrm{e}}$ variance in earnings). One implication is that a rising rate of return (for example because of skill-based technological change) raises the $\log _{\mathrm{e}}$ variance in earnings, all else constant. The impact of an overall increase in education is

$$
\frac{\partial \sigma^{2}(\ln Y)}{\partial \bar{S}}=2\left[\sigma^{2}\left(\alpha_{1}\right)-\sigma^{2}\left(\alpha_{2}\right)\right] \bar{S}-2 \sigma^{2}\left(\alpha_{2}\right)(\bar{A}-5)
$$

which can easily be positive. In fact using data from 1959, Chiswick and Mincer find $\frac{\partial \sigma^{2}(\ln Y)}{\partial \bar{S}}=.013$. So raising average education does not appear to narrow the earnings distribution. However, narrowing the variance in education, such as raising education levels for the lower income population relative to the well to do could narrow earnings distribution. Here Chiswick and Mincer find $\frac{\partial \sigma^{2}(\ln Y)}{\partial \sigma(S)}=.046$. In short, the Mincer human capital model can be used to predict changes in the earnings distribution. 


\section{Critiques of the Human Capital Approach}

Some view the Mincer earnings function as a reduced form supply and demand model. But because very few (if any) independent variables are demand determined, others view the lifecycle human capital model as essentially emanating from the perspective of the worker. Workers, over their lives, purchase human capital to enhance their earnings in any job they take. Becker denotes this as general training since such human capital enhances a worker's productivity in any establishment he or she is employed. As a proportion of a worker's time, investments are large when they are young, but taper off as they get older. Assuming a positive correlation between a worker's productivity and his or her wage, this decline in human capital investment leads to the concave earnings profile typically observed in virtually all countries' crosssectional data.

Not all agree that a positive correlation between a worker's wage and a worker's productivity is upheld in the data. Medoff and Abraham (1980) allegedly test this proposition using supervisor ratings to assess productivity. However, one major problem is that these supervisor ratings (usually an ordinal five-level scale) need not reflect actual productivity. Supervisor standards can easily deviate from one supervisor to another. Further, supervisor ratings can be job dependent. A mediocre ranking for corporate manager might imply far greater productivity than an excellent rating for a menial worker. In this context, Brown (1994) finds wages uncorrelated with supervisor ratings for a sample of workers in 3000 manufacturing plants. Nevertheless, this possible weak correlation between wages and productivity in part motivated a literature on effort enhancing contracts as a means for employers to spur worker productivity. However, effort enhancing incentive based contracts can be linked to the human capital model. In fact, not linking effort enhancing contracts to the lifecycle human capital model can bias predictions from both approaches. 
Effort enhancing contracts take many forms. Piece rates, tournaments, up-or-out promotion rules, profit sharing, team incentives, and efficiency wages are but a few examples. Recall that within the human capital model the worker maximizes the present value of lifetime earnings (depicted as equation (1)) subject to the rate at which human capital is produced (equation (2)) as specified in the Hamiltonian equation (3). In this model, human capital accumulation is endogenous, but the rental rate per unit of human capital (that is, the wage rate) is exogenous. In contrast, effort enhancing contract models assume lifetime human capital accumulation to be exogenous, but that one's wage per unit of human capital (w) is endogenous (Polachek and Siebert, 1993: 261-265). Here the firm pays a premium based on the amount of effort it can induce. Take the case of the efficiency wage model. Here, one's wage is related to one's effort (E) so that $w=w(E)$ with $\mathrm{w}_{\mathrm{E}}>0$ and $\mathrm{w}_{\mathrm{EE}}<0$. Given this wage structure, the problem for the worker is to choose an effort level to equate his or her marginal gain in wage (from added effort) to the marginal disutility of expending extra effort. Letting $\mathrm{Y}=[1-\mathrm{s}(\mathrm{t})] \mathrm{w}(\mathrm{E}) \mathrm{K}(\mathrm{t})$ be a worker's earnings (where $\mathrm{s}(\mathrm{t})$ is the amount of predetermined time spent in investment and the other variables are as previously defined), and expressing a worker's utility as $\mathrm{U}=\mathrm{U}(\mathrm{Y}, \mathrm{E})$ where $\mathrm{U}_{\mathrm{Y}}>0$ and $\mathrm{U}_{\mathrm{YY}}<0$ denotes the positive utility of earnings which increase at a decreasing rate, and $\mathrm{U}_{\mathrm{E}}<0$ and $\mathrm{U}_{\mathrm{EE}}>0$ the disutility associated with putting out effort, a worker can determine optimal effort on the job.

Embedding the problem in a human capital life cycle context implies that the individual chooses investment time $[\mathrm{s}(\mathrm{t})]$ in each time period as well as an optimal overall effort level (E) to maximize lifetime utility

$$
\operatorname{Max} \int_{0}^{T} U(Y, E) e^{-r t} d t
$$

subject to the constraints just imposed by $\mathrm{U}(\mathrm{Y}, \mathrm{E})$ and the human capital production function given earlier in equation (2). With such a representation, one can determine how workers choose effort levels to exactly balance higher wages per unit of effort with the utility losses endemic to effort. Similarly, at the same time, one can determine how workers choose investment levels in each period to balance the present value of marginal 
gains and costs of investing. Also, more complicated wage schemes can also be analyzed in a similar framework.

Models in which workers post bonds (Becker and Stigler, 1974 or Lazear, 1979 and 1981) introduce time into the wage function, so that $\mathrm{w}=\mathrm{w}(\mathrm{E}, \mathrm{t})$. Paying a wage premium after a worker successfully completes a certain tenure level, for example such that $\mathrm{w}(\mathrm{E}, \mathrm{t})>\mathrm{W}^{*}(\mathrm{E})$ for $\mathrm{t}>\mathrm{t}^{*}$, but $\mathrm{w}(\mathrm{E}, \mathrm{t})<\mathrm{W}^{*}(\mathrm{E})$ for $\mathrm{t}<\mathrm{t}^{*}$, implies that increased effort in one time period is rewarded by higher wages in subsequent time periods. Not only does this incentive scheme enhance effort, but it also decreases turnover since it is advantageous to stay with the firm long enough to recoup one's bond. However, replacing $\mathrm{w}(\mathrm{E})$ with $\mathrm{w}(\mathrm{E}, \mathrm{t})$ can have consequences on both effort as well as human capital investments in each time period.

According to the lifecycle optimization process (in each time period, t) one purchases human capital investment up to the point where the costs per extra unit of investment just equals the present value of investment gains for the marginal unit of investment, so that

$$
\int_{0}^{T-t} w(\tau) e^{-r \tau} d \tau
$$

posting a bond lowers one's current wage but raises one's future wage. This can affect the present value of investment gains in each time period (t) because marginal gains in later periods are higher than they otherwise would be if there were no incentive pay. Simply assume $\mathrm{w}(\mathrm{E}, \mathrm{T})>\mathrm{w}(\mathrm{E}, \mathrm{t})$ for all $\mathrm{t}<\mathrm{T}$, then marginal gain would decrease less quickly than otherwise yielding higher investment later in life compared to a wage contract with no wage incentive, where $w(E, t)$ to be the rental rate per unit of human capital stock (not earnings attributable to one's entire human capital stock which would be $\mathrm{w}(\mathrm{E}, \mathrm{t}) \mathrm{K}(\mathrm{t}))$. As such life cycle human capital investment paths are altered, causing workers to forgo investing until they get older. To my knowledge, the current literature does not consider this unintended distortion in the time path of investment caused by such 
incentive based contracts. In these models we abstracted from labor supply, but leisure and work hours are affected also affected (Jiang and Polachek, 1991).

Wage contract schemes can be embedded in a life cycle human capital accumulation framework. Embedding incentive contract models into a life cycle setting inextricably links efficiency wages to the life cycle human capital model. When looked at this way, human capital accumulation is affected by the compensation scheme, and this has implications regarding lifetime earnings profiles. As such, omitting human capital from contract models can have at least as many errors as omitting wage schemes from the analysis of human capital accumulation.

\section{Conclusion}

Many patterns emerge when examining how earnings are distributed across the population. We see that the educated earn more than the less-educated. We see that school quality matters, as does an individual's ability. We see that earnings rise with greater educational expenditure. We see that the young earn less than the old so that over the lifecycle an individual's earnings rise at a diminishing rate. We see that men earn more than women. We see that the gender wage gap for single men and single women is much smaller than the wage gap between married men and married women. We see that men are distributed differently across occupations than women. We see that for both men and women earnings depreciate with time out of the labor force. We see that earnings profiles are flatter for those anticipating work discontinuities. We see job mobility declines with tenure on the job. We see higher unemployment rates among the less educated. And, we see higher country growth rates the more educated the population.

Many theories have been used to explain some but not all these patterns. For example, screening models describe why education enhances earnings. Occupational segregations models portray why women are in different occupations than men. Crowding models elucidate why women earn less than men. Efficiency wage models justify unemployment. Matching models account for why job turnover declines with 
tenure. And productivity enhancement contract models provide an explanation for upward sloping age-earnings profiles.

Whereas each of these theories has some predictive power, they each deal with only a single aspect of the earnings distribution. Only one theory -- the human capital theory - has significant power in simultaneously explaining all these patterns. This review essay summarizes (and slightly extends) much the research emanating from Jacob Mincer's pioneering innovations in developing human capital theory to understand the earnings distribution. 
FIGURE 1

earinings Profiles

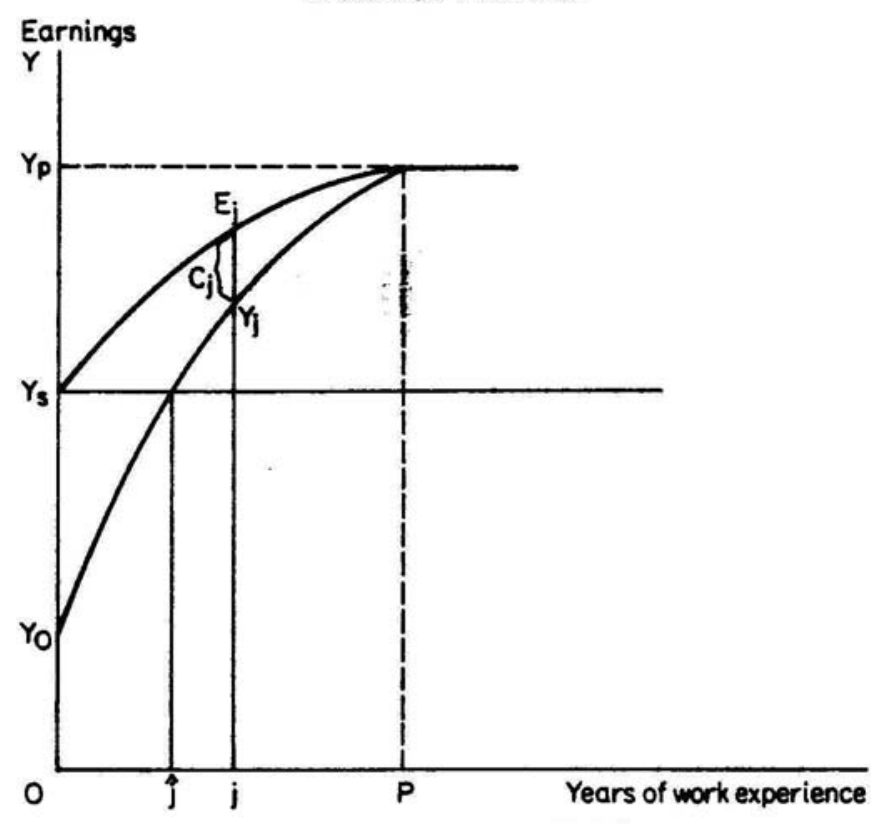

Source: Jacob Mincer, Schooling, Experience, and Earnings. 
Figure 2

\section{Experience Profiles of Variances of anmual earnings of} White, Nonfarm Men, 1959

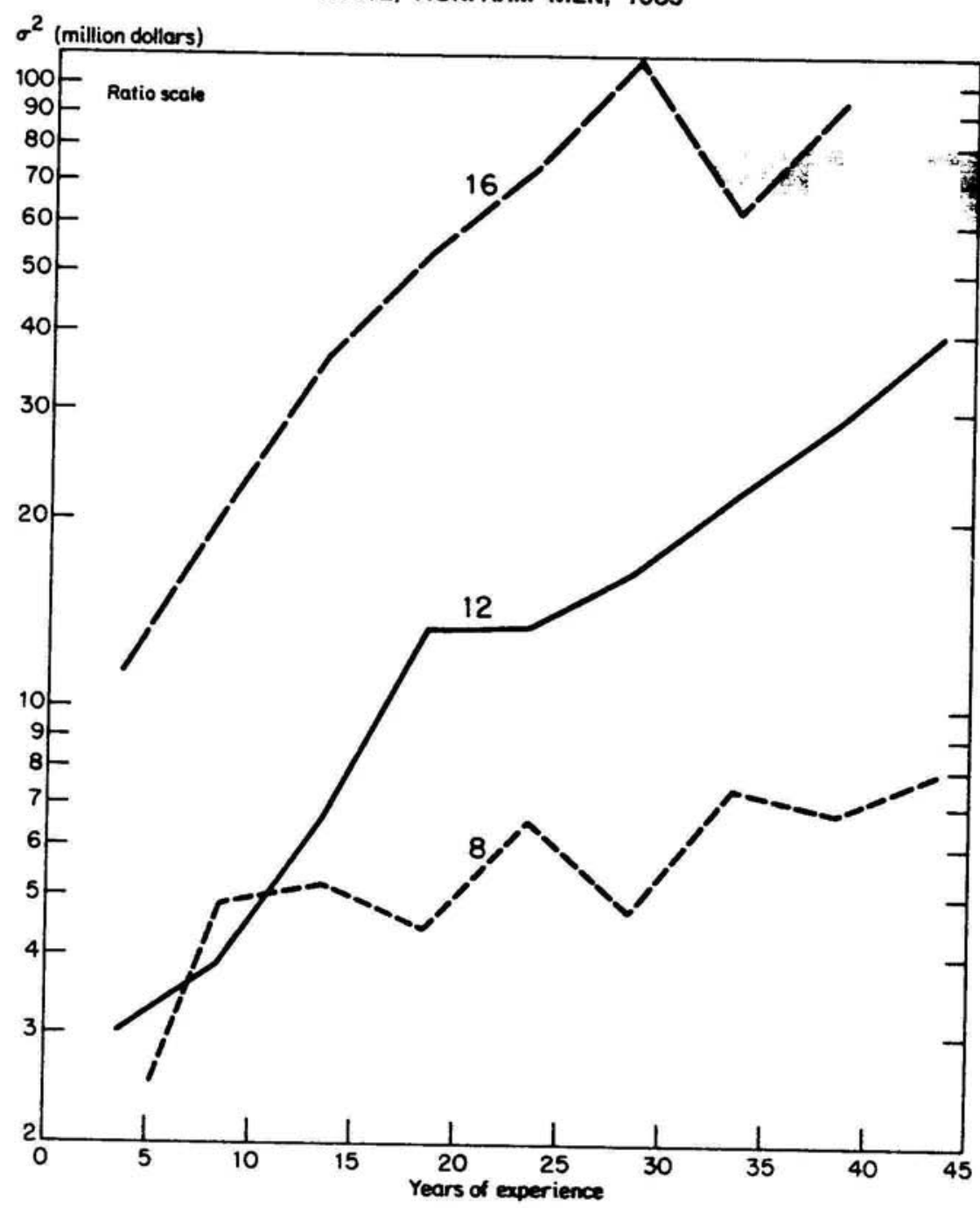

NOTE: Figures on curves indicate years of schooling completed. SOURCE: $1 / 1,000$ sample of U.S. Census, 1960.

Source: Jacob Mincer, Schooling, Experience and Earnings. 
Figure 3

experience profiles of log Variances of annual Earnings of White, nonfarm Men, 1959

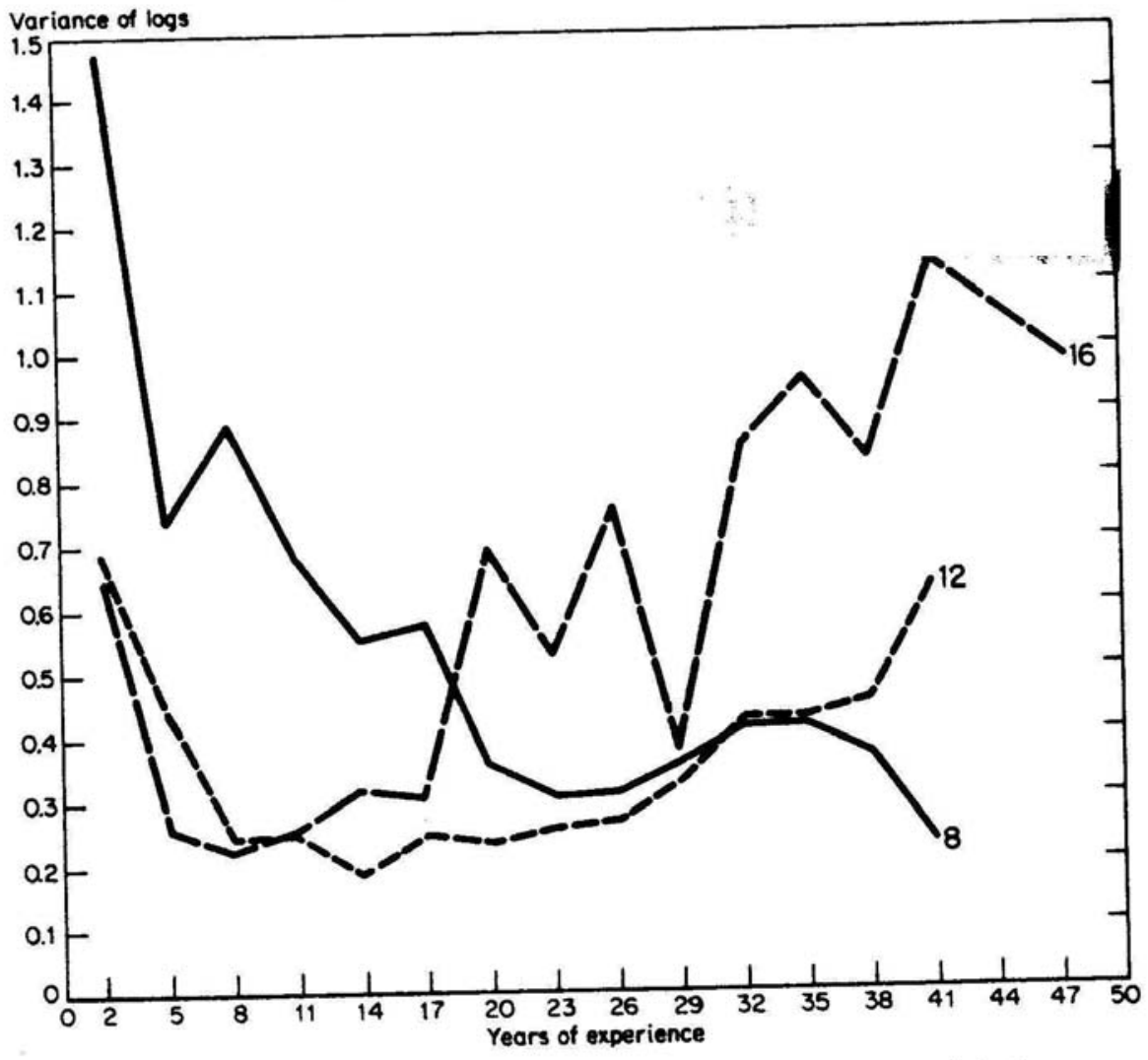

NOTE: Figures on curves indicate years of schooling completed. SOURCE: 1/1,000 sample of U.S. Census, 1960.

Source: Jacob Mincer, Schooling, Experience and Earnings. 
Figure 4

Standard Deviation of Hourly Eamings Over the Life Oycle, Australia, 1981

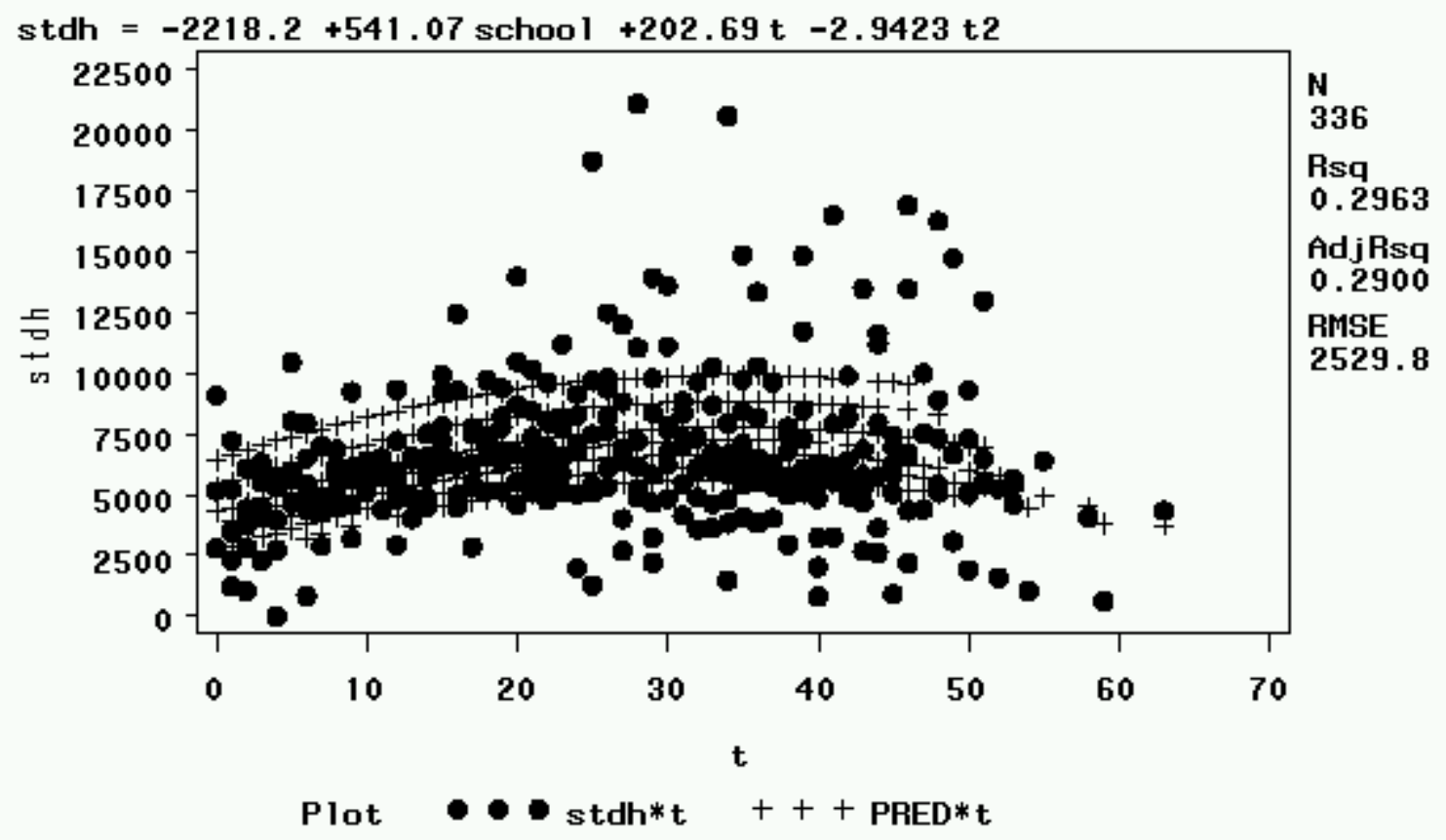

Source: Polachek (2003) 
Figure 5

Standard Deviation of Ln Hourly Eamings Over the Life Cycle, Australia, 1981

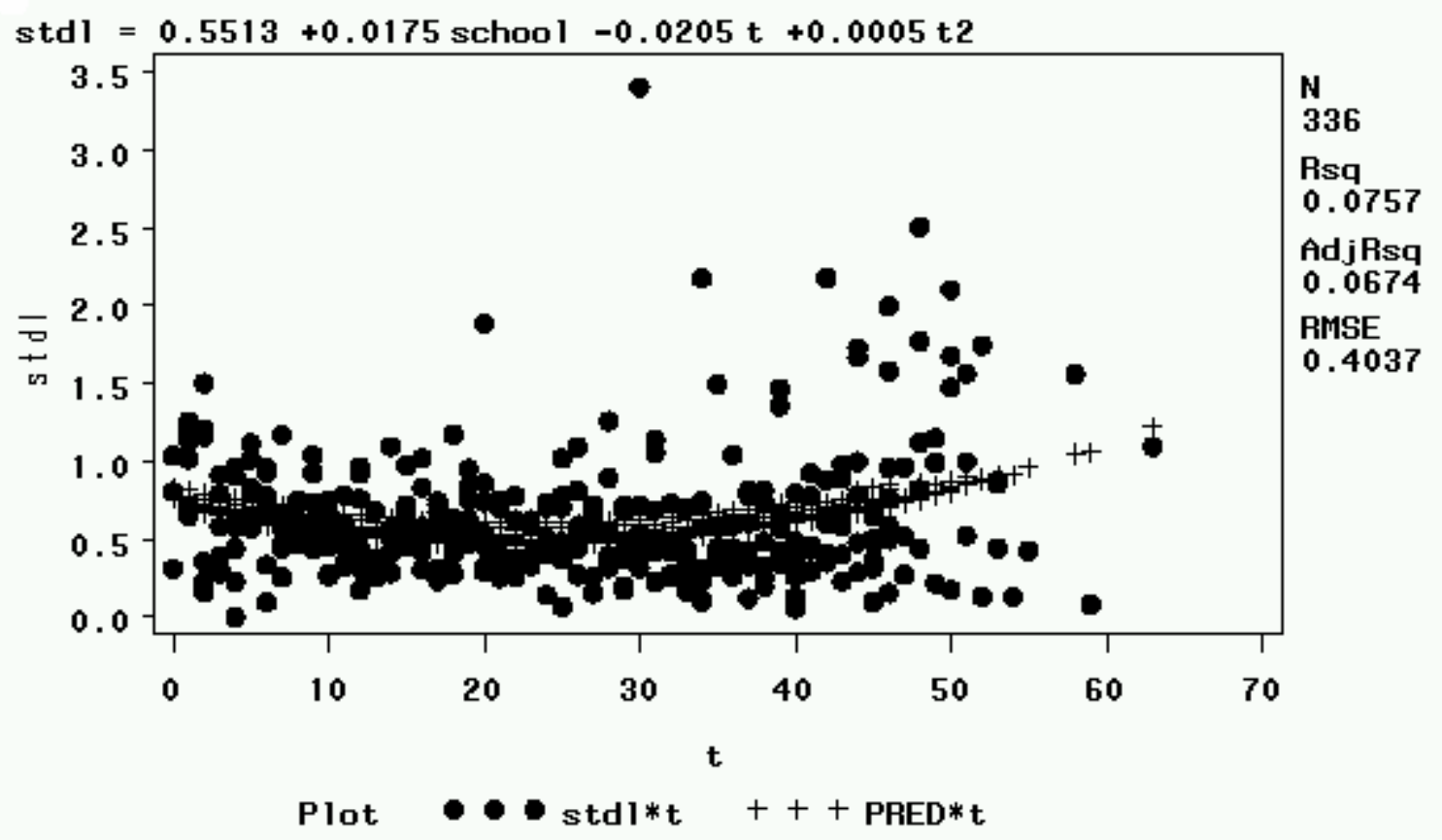

Source: Polachek (2003) 
Figure 6

Stanctard Deviation of Hourly Earnings Over the Life Oycle, Canada, 1997

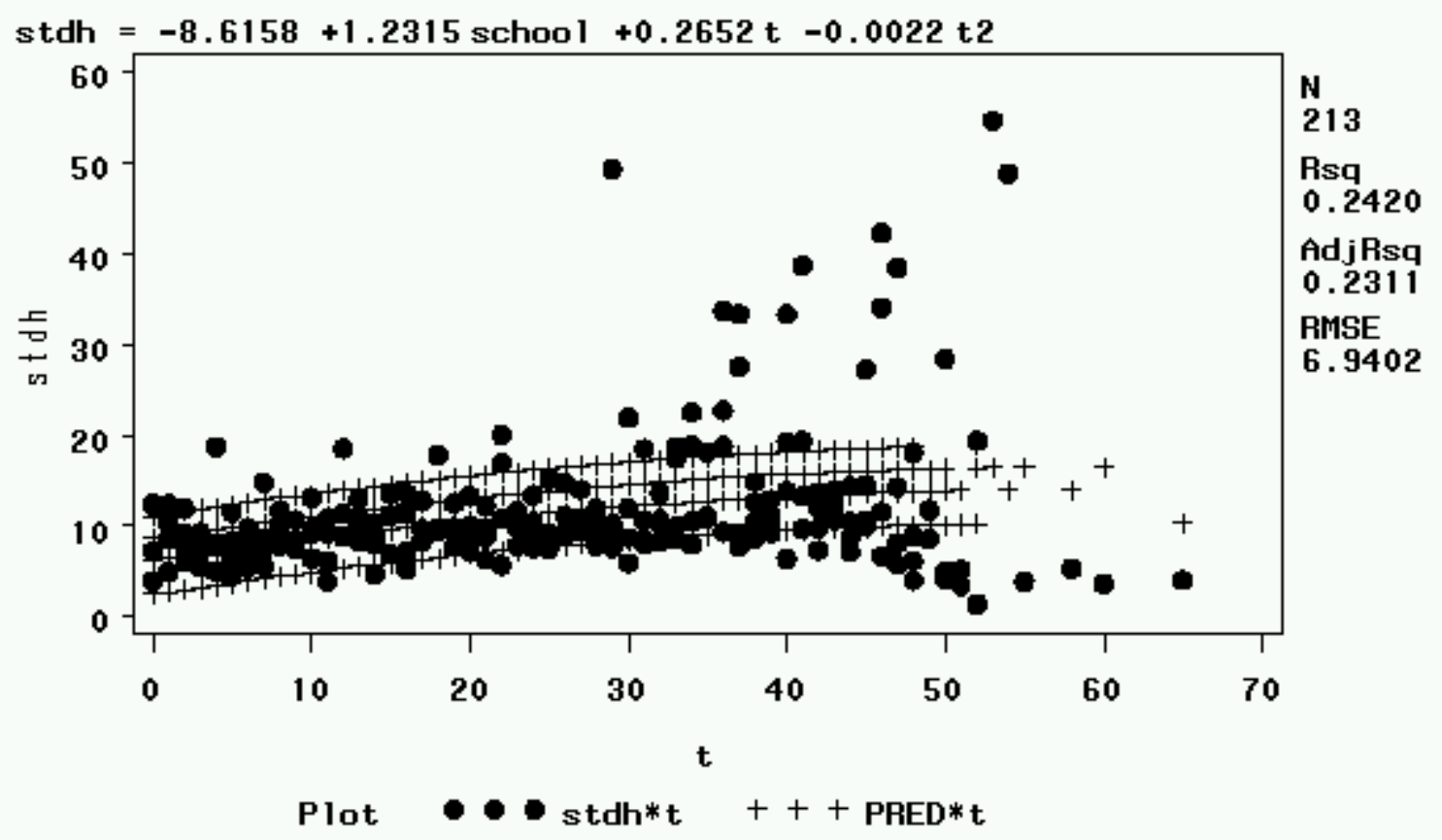

Source: Polachek (2003) 
Figure 7

Standard Deviation of Ln Hourly Earnings Over the Life Cycle, Carada, 1997

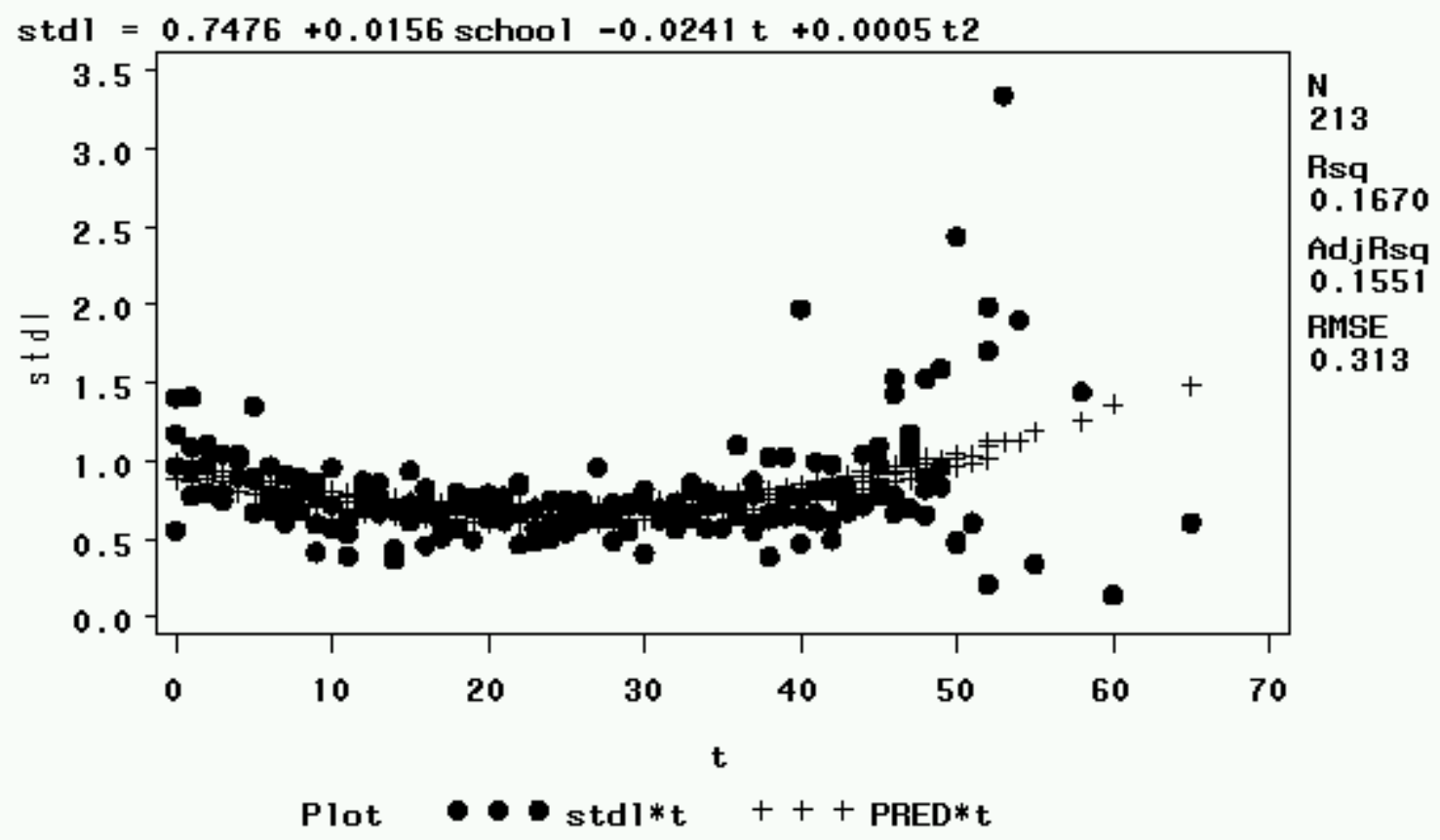

Source: Polachek (2003) 
Figure 8: U.S. Labor Force Participation by Gender, Marital Status and Age

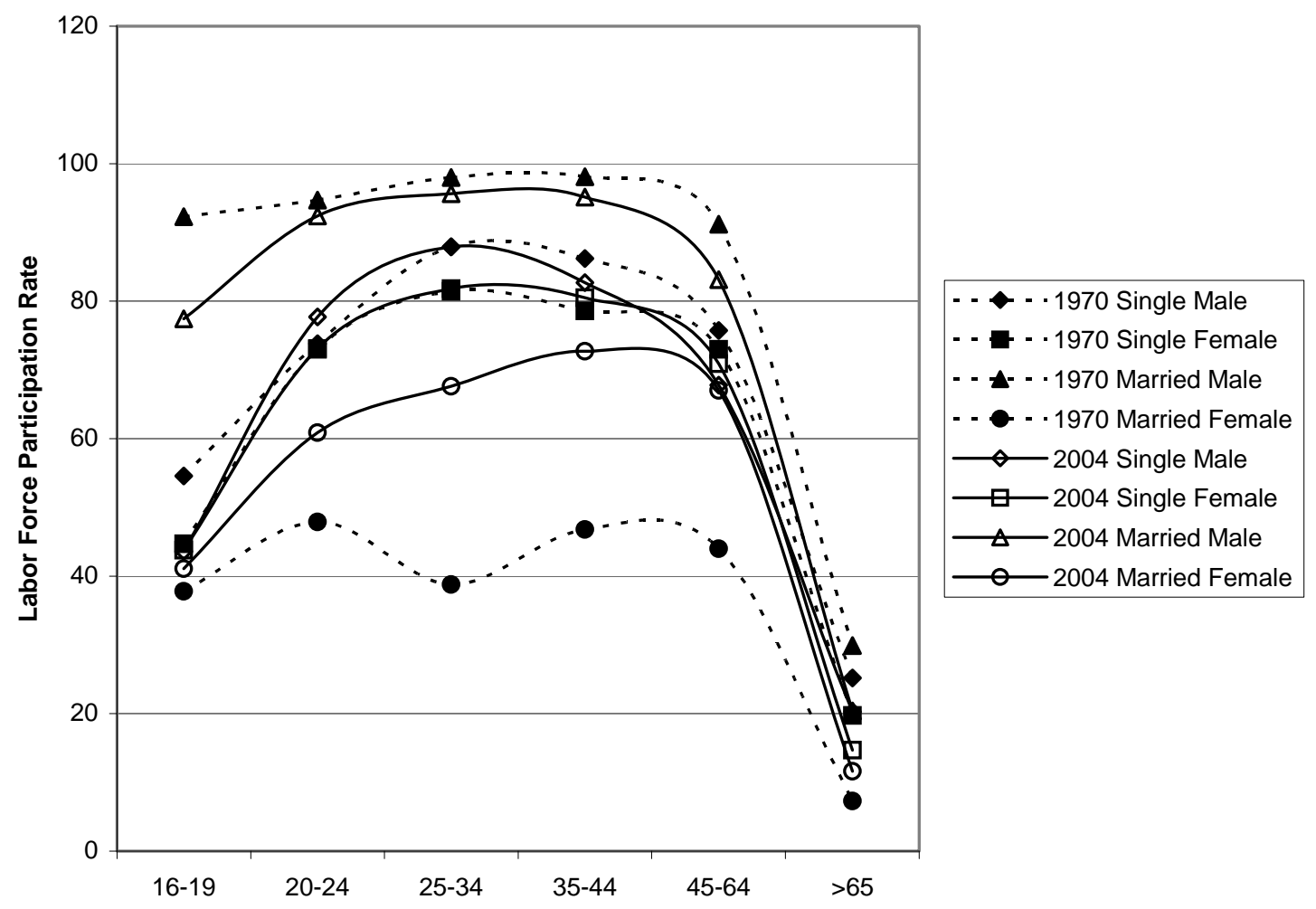


Figure 9: The Effect of Intermittent Labor Force Participation on Earnings

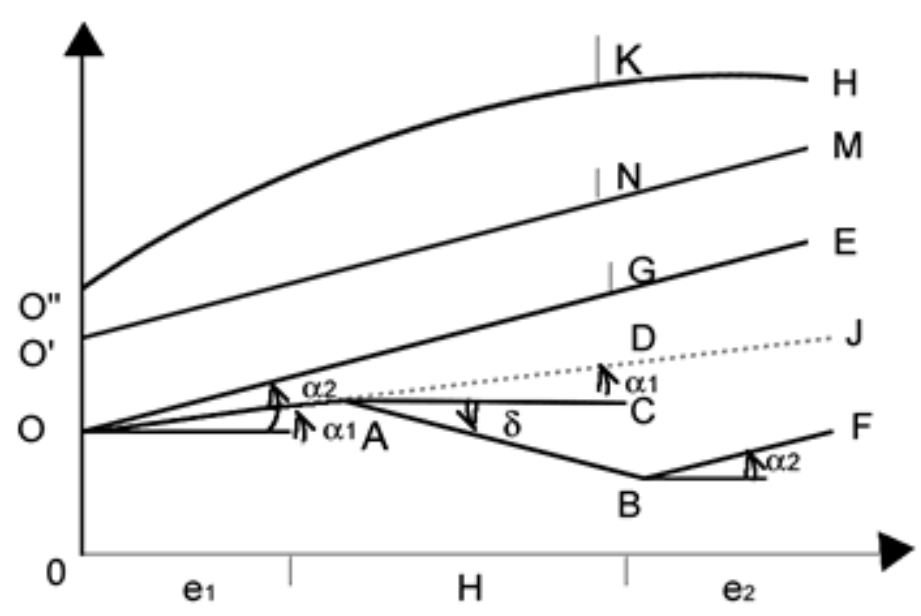


Figure 10: Male and Female Human Capital Investment Over the Lifecycle

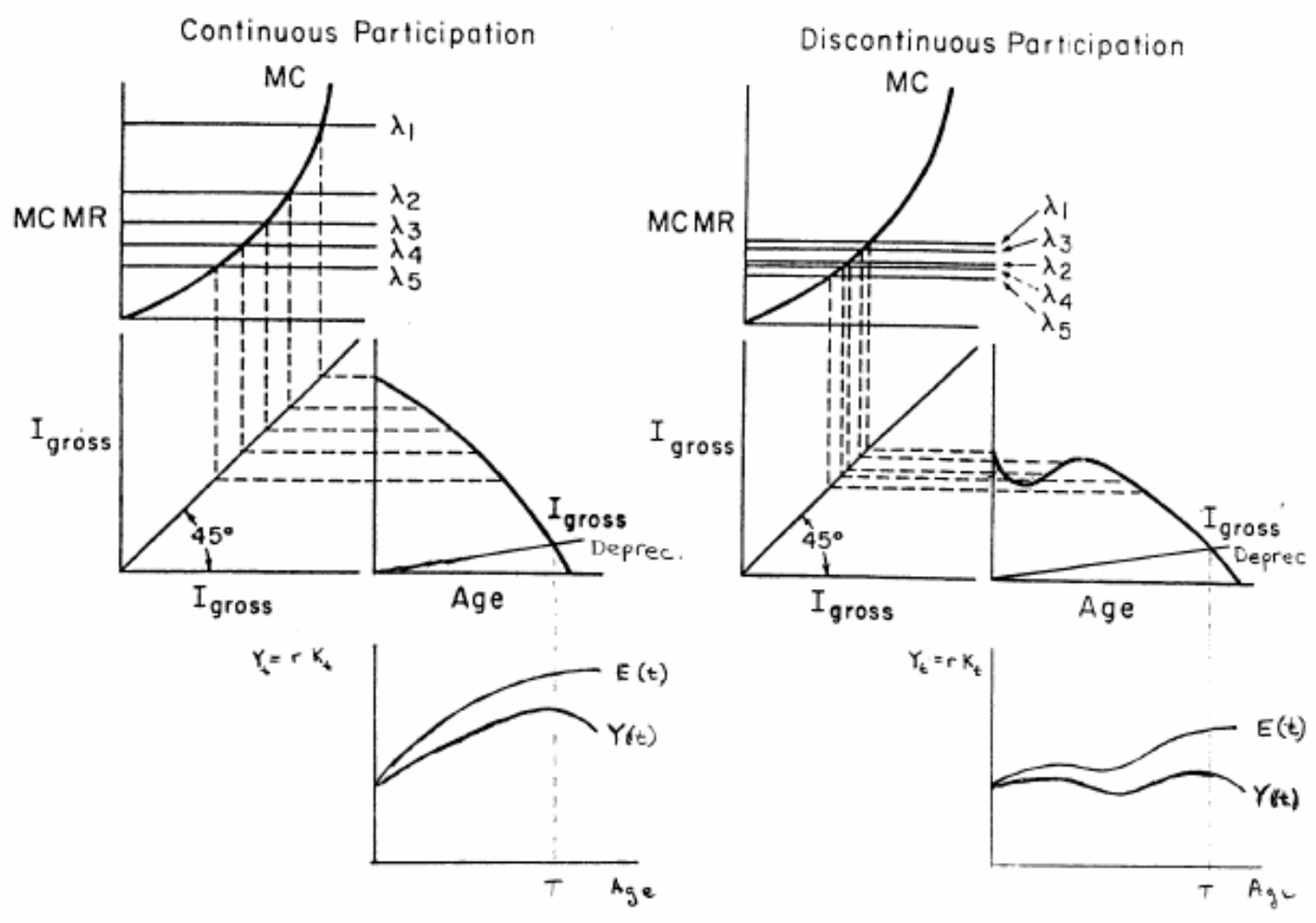

Adapted from: Polachek (1975a) 
Figure 11: Female-to-Male Wages and Married Female Labor Force Participation Rates

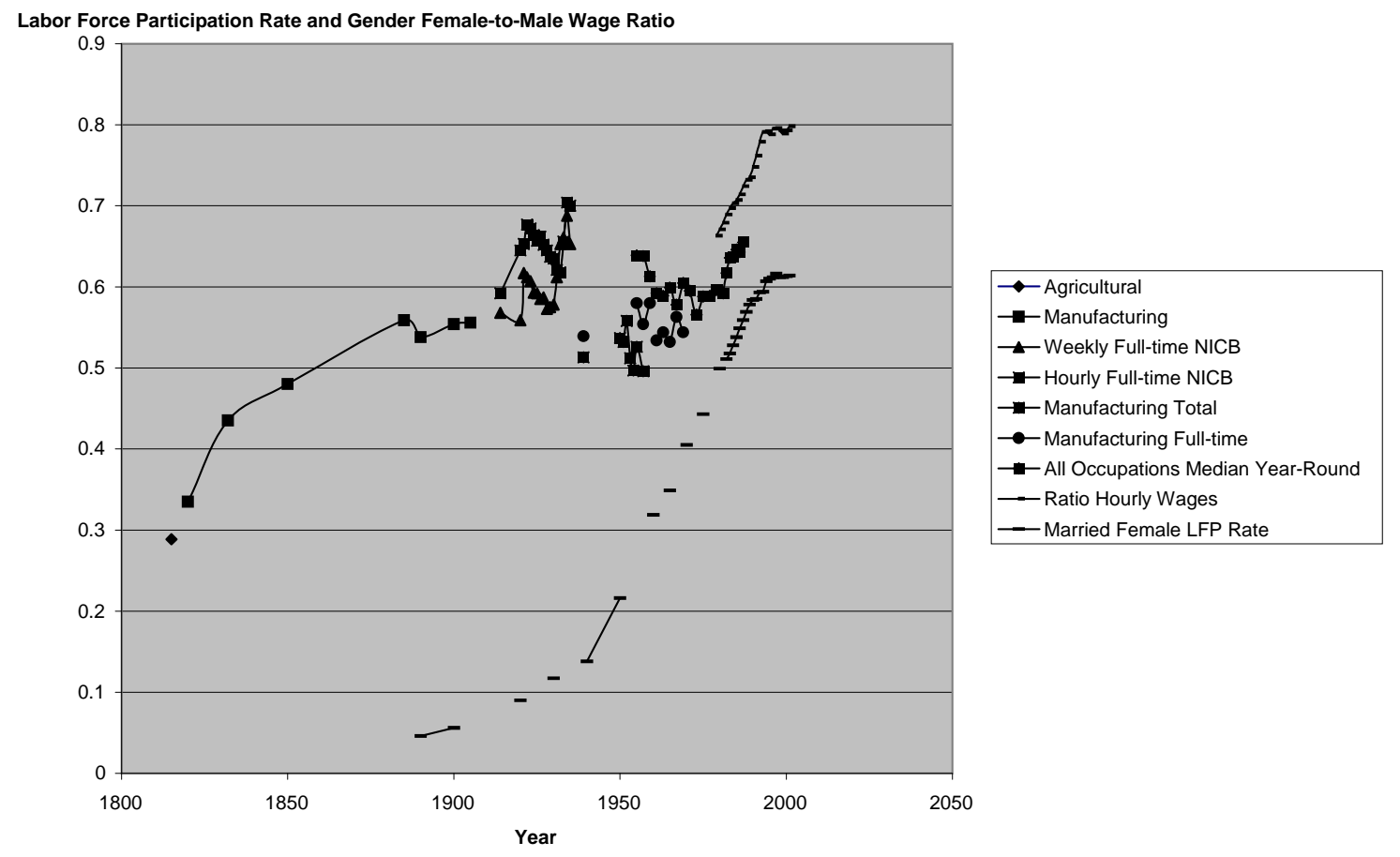

Sources: Agricultural through “All Occupations” data (Rows 2-8): C. Goldin, Understanding the Gender Gap, Table 3.1, pp. 60-1; Hourly Wage Ratio (Row9): June O'Neill, 2003 AEA Paper, based on CPS Outgoing Rotation Groups; Married women greater than age 15 labor force participation rate data for 18901950, Table 2.1 Page 17 of Golden, Understanding the Gender Gap; Married women labor force participation rates for 1960-1998, George Kurian, Datapedia of the United Sates 1790-2005, (Lanham, Md: Bernan Press),2001:95 Series DD4 based on US BLS Bulletin 2307, and unpublished data; and Married female labor force participation rate: 1998-2001. 2002 Statistical Abstract of the US, Table 569. 
Figure 12: Occupational Distribution of Employment by Gender and Year

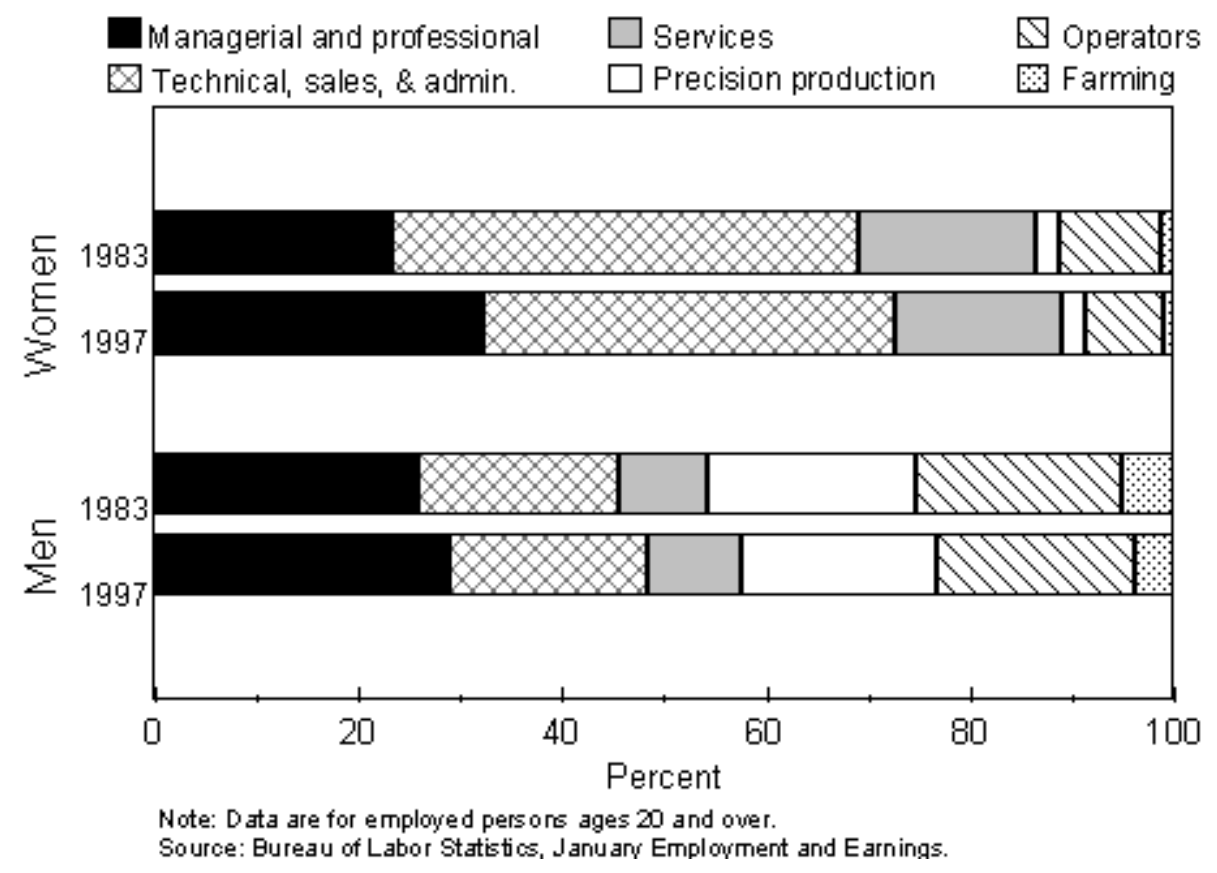

Source: Council of Economic Advisors (1998) 
Table 1: Average Weekly Earnings (2000 USD)

\begin{tabular}{lcccccccc} 
year & \multicolumn{2}{c}{$\underline{1970}$} & \multicolumn{2}{c}{1980} & \multicolumn{2}{c}{1990} & \multicolumn{2}{c}{$\underline{2000}$} \\
& Men & Women & Men & Women & Men & Women & Men & Women \\
\hline Race: White & 826 & 462 & 771 & 449 & 862 & 550 & 983 & 660 \\
Black & 537 & 373 & 577 & 433 & 631 & 507 & 696 & 580 \\
Age:16-24 & 488 & 382 & 433 & 339 & 401 & 338 & 409 & 376 \\
$25-34$ & 764 & 471 & 679 & 462 & 701 & 541 & 745 & 590 \\
35-44 & 888 & 457 & 884 & 483 & 949 & 603 & 1016 & 698 \\
$45-54$ & 892 & 471 & 903 & 479 & 1052 & 590 & 1137 & 734 \\
$55-64$ & 790 & 471 & 857 & 477 & 990 & 539 & 1115 & 631 \\
Education:< 8years & 599 & 342 & 571 & 355 & 523 & 330 & 498 & 347 \\
1-3 yrs high school & 688 & 373 & 608 & 370 & 610 & 375 & 551 & 406 \\
4 yrs high school & 764 & 444 & 677 & 414 & 661 & 447 & 668 & 473 \\
1-3 yrs college & 888 & 488 & 782 & 458 & 801 & 533 & 838 & 590 \\
4 yrs+ of college & 1221 & 715 & 1016 & 608 & 1236 & 783 & 1453 & 926 \\
\hline
\end{tabular}

Source: US Census 1970, 1980, 1990,2000

Full time full year workers aged 16-64 who work at least 35 hours per week

and 40 weeks per year in the year prior to the census year, and have positive wages.

CPI: 1970: 4.44; 1980: 2.09; 1990: 1.32. source: http://data.bls.gov/cgi-

bin/cpicalc.pl 
Table 2: Rates of Return to Education by Country

\begin{tabular}{|c|c|c|c|c|c|c|c|c|c|}
\hline & \multicolumn{3}{|c|}{ ISSP Data $^{1}$} & \multicolumn{3}{|c|}{ ISSP Data $^{2}$} & \multicolumn{3}{|c|}{ LIS Data $^{3}$} \\
\hline Country & $\begin{array}{c}\text { Number } \\
\text { Years }\end{array}$ & Males & Females & $\begin{array}{c}\text { Number } \\
\text { Years }\end{array}$ & Males & Females & $\begin{array}{c}\text { Number } \\
\text { Years }\end{array}$ & Males & Females \\
\hline Australia & 6 & 0.05 & 0.05 & 10 & 0.07 & 0.07 & 2 & 0.05 & 0.05 \\
\hline Austria & 8 & 0.04 & 0.06 & 11 & 0.07 & 0.09 & 3 & 0.12 & 0.11 \\
\hline Bangladesh & & & & 1 & & 0.28 & & & \\
\hline Belgium & & & & & & & 5 & 0.06 & 0.06 \\
\hline Brazil & & & & 1 & 0.13 & 0.12 & & & \\
\hline Bulgaria & 2 & 0.04 & 0.06 & 7 & 0.07 & 0.08 & & & \\
\hline Canada & 1 & 0.04 & 0.05 & 8 & 0.06 & 0.08 & 6 & 0.07 & 0.09 \\
\hline Chile & & & & 3 & 0.14 & 0.12 & & & \\
\hline Cyprus & & & & 4 & 0.04 & 0.09 & & & \\
\hline Czech Republic & 2 & 0.04 & 0.04 & 7 & 0.05 & 0.07 & 1 & 0.07 & 0.08 \\
\hline Czechoslovakia & 1 & 0.03 & 0.04 & & & & & & \\
\hline Denmark & & & & 4 & 0.04 & 0.04 & & & \\
\hline East Germany & 5 & 0.03 & 0.05 & 9 & 0.05 & 0.06 & & & \\
\hline Finland & & & & 2 & 0.04 & 0.03 & 1 & 0.13 & 0.10 \\
\hline Flanders & & & & 1 & 0.05 & & & & \\
\hline France & & & & 4 & 0.10 & 0.08 & 1 & 0.06 & 0.06 \\
\hline Germany & 9 & & & & 0.06 & 0.07 & 4 & 0.08 & 0.09 \\
\hline (West) & & 0.04 & 0.04 & 14 & & & & & \\
\hline Hungary & 3 & 0.08 & 0.08 & 9 & 0.08 & 0.08 & 3 & 0.11 & 0.11 \\
\hline Ireland & 6 & 0.09 & 0.09 & 9 & 0.10 & 0.10 & 4 & & \\
\hline Israel & 2 & 0.05 & 0.06 & 5 & 0.06 & 0.08 & 4 & 0.10 & 0.13 \\
\hline Italy & 6 & 0.04 & 0.05 & 10 & 0.04 & 0.07 & 7 & 0.09 & 0.09 \\
\hline Japan & 3 & 0.08 & 0.09 & 8 & 0.09 & 0.12 & & 0.08 & 0.08 \\
\hline Latvia & 1 & 0.07 & 0.08 & 5 & 0.06 & 0.06 & & & \\
\hline Luxembourg & & & & & & & 5 & 0.09 & 0.11 \\
\hline Mexico & & & & 2 & 0.10 & 0.10 & 8 & 0.14 & 0.16 \\
\hline Netherlands & 7 & 0.03 & 0.02 & 6 & 0.04 & 0.04 & 4 & 0.07 & 0.07 \\
\hline New Zealand & 5 & 0.03 & 0.03 & 7 & 0.05 & 0.05 & & & \\
\hline Northern & 5 & & & & 0.14 & 0.14 & & & \\
\hline Ireland & & 0.17 & 0.15 & 5 & & & & & \\
\hline Norway & 7 & 0.02 & 0.03 & 12 & 0.05 & 0.06 & & & \\
\hline Philippines & 1 & 0.11 & 0.19 & 5 & 0.13 & 0.13 & & & \\
\hline Poland & 5 & & & 9 & 0.09 & 0.09 & & & \\
\hline Portugal & & & & 3 & 0.08 & 0.10 & & & \\
\hline Russia & 5 & 0.04 & 0.05 & 10 & 0.06 & 0.06 & 3 & 0.06 & 0.07 \\
\hline Slovak Republic & 1 & 0.05 & 0.06 & 3 & 0.05 & 0.07 & & & \\
\hline Slovenia & 3 & 0.08 & 0.10 & 8 & 0.10 & 0.10 & & & \\
\hline Spain & 2 & 0.05 & 0.04 & 6 & 0.06 & 0.07 & 2 & 0.08 & 0.11 \\
\hline Sweden & 2 & 0.02 & 0.03 & 7 & 0.05 & 0.04 & 2 & 0.08 & 0.06 \\
\hline Switzerland & 1 & 0.05 & 0.05 & 5 & 0.07 & 0.07 & 1 & 0.09 & 0.05 \\
\hline Taiwan & & & & 1 & 0.08 & 0.09 & & & \\
\hline United Kingdom & 11 & 0.13 & 0.13 & 16 & 0.09 & 0.10 & 5 & 0.09 & 0.10 \\
\hline
\end{tabular}




\begin{tabular}{|l|l|l|l|l|l|l|l|l|l|} 
United States & 11 & 0.07 & 0.10 & 16 & 0.09 & 0.12 & 6 & 0.11 & 0.13 \\
\hline
\end{tabular}

${ }^{1}$ Source: Philip Trostel, Ian Walker, Paul Woolley, "Estimates of the economic return to schooling for 28 countries," Labour Economics 9(2002): 1-16, using International Social Survey Programme data, 19851995..

${ }^{2}$ Computed over various years from 1980-2000 using ISSP data by author.

${ }^{3}$ Computed over various years from $1980-2000$ using LIS data by author. 
Table 3: Mincer Earnings Functions By Country and Year (LIS Data)

\begin{tabular}{|c|c|c|c|c|c|}
\hline Country & Year & Constant & Schooling & $t$ & t-squared \\
\hline Australia & 1981 & 8.417 & 0.051 & 0.056 & -0.0011 \\
\hline Australia & 1985 & 8.315 & 0.055 & 0.082 & -0.0015 \\
\hline Australia & 1989 & 1.644 & 0.048 & 0.030 & -0.0005 \\
\hline Australia & 1994 & 8.854 & 0.058 & 0.073 & -0.0015 \\
\hline Belgium & 1985 & 7.344 & 0.048 & 0.046 & -0.0008 \\
\hline Belgium & 1988 & 7.233 & 0.058 & 0.048 & -0.0008 \\
\hline Belgium & 1992 & -0.072 & 0.052 & 0.034 & -0.0005 \\
\hline Belgium & 1997 & 4.829 & 0.087 & 0.039 & -0.0005 \\
\hline Canada & 1981 & 1.293 & 0.051 & 0.039 & -0.0007 \\
\hline Canada & 1987 & 0.578 & 0.082 & 0.074 & -0.0013 \\
\hline Canada & 1991 & 0.943 & 0.079 & 0.063 & -0.0012 \\
\hline Canada & 1994 & 0.885 & 0.079 & 0.068 & -0.0012 \\
\hline Canada & 1997 & 0.648 & 0.091 & 0.068 & -0.0012 \\
\hline Canada & 1998 & 1.317 & 0.068 & 0.043 & -0.0007 \\
\hline Czech Republic & 1992 & 0.556 & 0.057 & 0.052 & -0.0010 \\
\hline Czech Republic & 1996 & -1.844 & 0.076 & 0.039 & -0.0007 \\
\hline Denmark & 1987 & 9.784 & 0.086 & 0.106 & -0.0021 \\
\hline Denmark & 1992 & 9.130 & 0.101 & 0.155 & -0.0030 \\
\hline Denmark & 1995 & 9.253 & 0.106 & 0.139 & -0.0027 \\
\hline Denmark & 1997 & 9.092 & 0.124 & 0.130 & -0.0028 \\
\hline Finland & 1987 & 7.548 & 0.197 & 0.130 & -0.0031 \\
\hline Finland & 1991 & 7.757 & 0.180 & 0.150 & -0.0035 \\
\hline Finland & 2000 & 8.010 & 0.128 & 0.162 & -0.0032 \\
\hline Finland & 1995 & 8.007 & 0.119 & 0.197 & -0.0045 \\
\hline France & 1984 & 10.197 & 0.067 & 0.040 & -0.0005 \\
\hline France & 1989 & 10.033 & 0.077 & 0.055 & -0.0007 \\
\hline France & 1994 & 2.081 & 0.091 & 0.059 & -0.0008 \\
\hline Germany & 1981 & 2.007 & 0.048 & 0.043 & -0.0007 \\
\hline Germany & 1989 & 0.638 & 0.089 & 0.117 & -0.0019 \\
\hline Germany & 1994 & 1.117 & 0.079 & 0.101 & -0.0017 \\
\hline Hungary & 1991 & 9.929 & 0.102 & 0.080 & -0.0015 \\
\hline Hungary & 1994 & 10.023 & 0.158 & 0.073 & -0.0015 \\
\hline Hungary & 1999 & 10.404 & 0.155 & 0.079 & -0.0017 \\
\hline Ireland & 1994 & -0.717 & 0.100 & 0.094 & -0.0015 \\
\hline Ireland & 1995 & -0.526 & 0.092 & 0.089 & -0.0014 \\
\hline Ireland & 1996 & -0.517 & 0.098 & 0.079 & -0.0012 \\
\hline Israel & 1986 & 7.486 & 0.111 & 0.076 & -0.0012 \\
\hline Israel & 1992 & 8.443 & 0.101 & 0.084 & -0.0013 \\
\hline Israel & 1997 & 0.999 & 0.131 & 0.058 & -0.0008 \\
\hline Italy & 1986 & 8.106 & 0.061 & 0.065 & -0.0010 \\
\hline Italy & 1991 & 8.826 & 0.046 & 0.040 & -0.0006 \\
\hline Italy & 1995 & 0.612 & 0.077 & 0.066 & -0.0010 \\
\hline Luxembourg & 1985 & 11.816 & 0.071 & 0.066 & -0.0010 \\
\hline Luxembourg & 1991 & 4.236 & 0.081 & 0.066 & -0.0010 \\
\hline
\end{tabular}




\begin{tabular}{|c|c|c|c|c|c|} 
Luxembourg & 1994 & 4.324 & 0.083 & 0.071 & -0.0011 \\
\hline Mexico & 1984 & -4.085 & 0.147 & 0.070 & -0.0010 \\
Mexico & 1989 & -1.230 & 0.143 & 0.059 & -0.0008 \\
Mexico & 1992 & -0.803 & 0.159 & 0.060 & -0.0008 \\
Mexico & 1994 & -0.818 & 0.170 & 0.066 & -0.0009 \\
Mexico & 1996 & -0.621 & 0.168 & 0.068 & -0.0009 \\
Mexico & 1998 & -0.164 & 0.165 & 0.065 & -0.0009 \\
\hline Netherlands & 1983 & 1.709 & 0.071 & 0.044 & -0.0007 \\
Netherlands & 1987 & 8.993 & 0.075 & 0.079 & -0.0012 \\
Netherlands & 1991 & 7.533 & 0.103 & 0.174 & -0.0031 \\
Netherlands & 1994 & 7.484 & 0.095 & 0.188 & -0.0034 \\
\hline Norway & 1991 & 8.822 & 0.111 & 0.124 & -0.0025 \\
Norway & 1995 & 8.985 & 0.097 & 0.150 & -0.0029 \\
\hline Poland & 1986 & 11.627 & 0.046 & 0.044 & -0.0008 \\
Poland & 1992 & 9.467 & 0.052 & 0.022 & -0.0003 \\
Poland & 1995 & 7.700 & 0.062 & 0.033 & -0.0006 \\
\hline R.O.C. - Taiwan & 1981 & 10.221 & 0.094 & 0.068 & -0.0012 \\
R.O.C. - Taiwan & 1986 & 10.554 & 0.087 & 0.065 & -0.0011 \\
R.O.C. - Taiwan & 1991 & 11.136 & 0.085 & 0.062 & -0.0010 \\
R.O.C. - Taiwan & 1995 & 11.569 & 0.059 & 0.084 & -0.0017 \\
\hline Russia & 1992 & 10.052 & 0.033 & 0.029 & -0.0007 \\
Russia & 1995 & 9.700 & 0.042 & 0.029 & -0.0008 \\
\hline Slovak Republic & 1992 & 4.930 & 0.063 & 0.054 & -0.0010 \\
\hline Spain & 1980 & 12.074 & 0.084 & 0.045 & -0.0007 \\
Spain & 1990 & 12.118 & 0.086 & 0.080 & -0.0011 \\
\hline Sweden & 1992 & 9.266 & 0.059 & 0.170 & -0.0032 \\
Sweden & 1995 & 3.321 & 0.072 & 0.030 & -0.0006 \\
\hline Switzerland & 1992 & 1.751 & 0.060 & 0.056 & -0.0008 \\
\hline United Kingdom & 1991 & 0.227 & 0.092 & 0.055 & -0.0009 \\
United Kingdom & 1994 & 0.081 & 0.107 & 0.062 & -0.0010 \\
United Kingdom & 1995 & 0.255 & 0.095 & 0.058 & -0.0009 \\
United Kingdom & 1999 & 0.380 & 0.094 & 0.054 & -0.0009 \\
\hline United States & 1969 & 5.744 & 0.120 & 0.140 & -0.0023 \\
United States & 1974 & -0.154 & 0.076 & 0.070 & -0.0012 \\
United States & 1979 & 0.753 & 0.061 & 0.038 & -0.0006 \\
United States & 1986 & 0.300 & 0.090 & 0.069 & -0.0011 \\
United States & 1991 & 0.002 & 0.101 & 0.090 & -0.0015 \\
United States & 1994 & -0.023 & 0.112 & 0.082 & -0.0014 \\
United States & 1997 & -0.124 & 0.123 & 0.083 & -0.0014 \\
United States & 2000 & -0.080 & 0.134 & 0.076 & -0.0013 \\
\hline & & & & & \\
\hline
\end{tabular}


Table 4

Schooling rates of Return Computed Within Pairs

\begin{tabular}{|cc|}
\hline Pair & Rate of Return \\
\hline MZ & 0.027 \\
DZ & 0.059 \\
\hline
\end{tabular}

Source: Taubman (1976)

Table 5: Modified Mincer Earnings Function by Gender and Race

Sex Regression

\begin{tabular}{lcccccc} 
Category & Intercept & Schooling & Tenure & Experience & Sex & $\mathrm{R}^{2}$ \\
\hline All & 5.12 & .075 & .0012 & .0051 & -.351 & 0.4114 \\
White & $(182.6)$ & $(38.3)$ & $(15.1)$ & $(8.3)$ & $(-31.6)$ & \\
& 5.24 & .068 & .0011 & .0056 & -.375 & 0.4219 \\
Black & $(140.9)$ & $(26.6)$ & $(12.3)$ & $(7.3)$ & $(27.3)$ & \\
& 5.18 & .064 & .0011 & .0029 & -.289 & 0.2755 \\
& $(108.9)$ & $(17.7)$ & $(7.9)$ & $(2.8)$ & $(15.7)$ & \\
Category & Intercept & Schooling & Tenure & Experience & Race & $\mathrm{R}^{2}$ \\
\hline All & 5.07 & .067 & .0014 & .0067 & -.133 & 0.2973 \\
& $(152.5)$ & $(29.6)$ & $(15.9)$ & $(9.9)$ & $(10.1)$ & \\
Male & 5.36 & .060 & .0011 & .0056 & -.180 & 0.3412 \\
& $(137.0)$ & $(23.2)$ & $(11.7)$ & $(7.1)$ & $(10.9)$ & \\
Female & 4.72 & .082 & .0013 & .0028 & -.043 & 0.2817 \\
& $(98.4)$ & $(24.0)$ & $(9.2)$ & $(2.8)$ & $(2.5)$ & \\
\hline
\end{tabular}

Source: Kamalich and Polachek (1982). 
Table 6: Mincer Earnings Functions Incorporating A Gender Categorical Variable

\begin{tabular}{|l|r|r|r|r|r|r|}
\hline & \multicolumn{1}{|c|}{1940} & \multicolumn{1}{c|}{1960} & \multicolumn{1}{c|}{1980} & \multicolumn{1}{c|}{1990} & \multicolumn{1}{c|}{$\mathbf{2 0 0 0}$} & \multicolumn{1}{c|}{2005} \\
\hline intercept & -2.40361 & -0.4547 & 0.4301 & 0.51425 & 0.71192 & 0.65928 \\
\hline years of school & 0.10505 & 0.07157 & 0.07747 & 0.10213 & 0.11228 & 0.12565 \\
\hline potential experience & 0.05346 & 0.03902 & 0.04678 & 0.04794 & 0.04375 & 0.04782 \\
\hline $\begin{array}{l}\text { potential experience } \\
\text { squared }\end{array}$ & -0.00073 & -0.00066 & -0.0008 & -0.00082 & -0.00076 & -0.00085 \\
\hline Female & -0.41163 & -0.43343 & 0.35762 & -0.2842 & -0.25076 & -0.24251 \\
\hline observations & 10472 & 13666 & 17185 & 18522 & 19805 & 20164 \\
\hline R-Square & 0.2464 & 0.2246 & 0.2201 & 0.2518 & 0.2528 & 0.2785 \\
\hline
\end{tabular}

Dependent Variable: In hourly wage

Source: US Decennial Census, 1940 to 2000 and American Community Survey for 2005 
Table 7

Mincer Earnings Functions Including Gender, Marital Status and Gender Interacted With Marital Status

\begin{tabular}{|c|c|c|c|c|c|c|c|c|}
\hline Country & Year & School & $\mathrm{t}$ & $\mathrm{t}^{\wedge} 2$ & Female & Female ${ }^{x}$ Married & Married & Race \\
\hline Australia & 1985 & 0.582 & 0.033 & -0.0006 & -0.005 & -0.191 & 0.098 & 0.048 \\
\hline Austria & 1994 & 0.118 & 0.054 & -0.0008 & -0.018 & -0.229 & 0.096 & 0.122 \\
\hline Canada & 1987 & 0.080 & 0.045 & -0.0006 & -0.081 & -0.348 & 0.301 & \\
\hline Canada & 1991 & 0.078 & 0.044 & -0.0007 & -0.148 & -0.230 & 0.191 & \\
\hline Canada & 1994 & 0.076 & 0.048 & -0.0008 & -0.110 & -0.239 & 0.216 & \\
\hline Canada & 1997 & 0.082 & 0.050 & -0.0008 & -0.110 & -0.265 & 0.212 & \\
\hline Canada & 1098 & 0.080 & 0.035 & -0.0005 & -0.181 & -0.138 & 0.164 & \\
\hline Canada & 2000 & 0.084 & 0.035 & -0.0006 & -0.191 & -0.112 & 0.144 & \\
\hline Czechoslovakia & 1992 & 0.077 & 0.037 & -0.0005 & 0.033 & -0.367 & 0.245 & -0.087 \\
\hline Finland & 1991 & 0.120 & 0.092 & -0.0016 & -0.002 & -0.024 & -0.137 & 0.074 \\
\hline France & 1994 & 0.096 & 0.056 & -0.0008 & -0.133 & -0.135 & 0.111 & 0.016 \\
\hline Ireland & 1994 & 0.100 & 0.057 & -0.0008 & -0.018 & -0.341 & 0.367 & 0.239 \\
\hline Ireland & 1995 & 0.093 & 0.050 & -0.0007 & -0.022 & -0.311 & 0.362 & 0.193 \\
\hline Ireland & 1996 & 0.099 & 0.039 & -0.0005 & -0.083 & -0.299 & 0.382 & 0.052 \\
\hline Italy & 1991 & 0.079 & 0.043 & -0.0006 & -0.024 & -0.117 & 0.112 & \\
\hline Italy & 1993 & 0.106 & 0.060 & -0.0008 & -0.067 & -0.093 & 0.119 & \\
\hline Italy & 1995 & 0.098 & 0.058 & -0.0008 & -0.052 & -0.082 & 0.138 & \\
\hline Italy & 1998 & 0.088 & 0.047 & -0.0006 & -0.051 & -0.088 & 0.137 & \\
\hline Italy & 2000 & 0.083 & 0.051 & -0.0007 & -0.073 & -0.057 & 0.120 & \\
\hline Luxembourg & 1991 & 0.061 & 0.045 & -0.0007 & 0.045 & -0.277 & 0.260 & 0.187 \\
\hline Luxembourg & 1994 & 0.064 & 0.047 & -0.0007 & -0.007 & -0.155 & 0.235 & 0.241 \\
\hline Luxembourg & 1997 & 0.084 & 0.049 & -0.0007 & -0.041 & -0.229 & 0.224 & 0.146 \\
\hline Luxembourg & 2000 & 0.090 & 0.041 & -0.0005 & -0.024 & -0.320 & 0.251 & 0.134 \\
\hline Mexico & 1996 & 0.148 & 0.058 & -0.0008 & 0.035 & -0.108 & 0.177 & \\
\hline Mexico & 1998 & 0.148 & 0.059 & -0.0008 & -0.062 & -0.048 & 0.131 & \\
\hline Mexico & 2000 & 0.129 & 0.048 & -0.0006 & -0.059 & -0.084 & 0.150 & \\
\hline Netherlands & 1983 & 0.071 & 0.041 & -0.0006 & -0.040 & -0.174 & 0.098 & \\
\hline Netherlands & 1994 & 0.077 & 0.067 & -0.0011 & -0.025 & -0.246 & 0.232 & \\
\hline Netherlands & 1999 & 0.092 & 0.077 & -0.0013 & -0.056 & -0.236 & 0.164 & \\
\hline Sweden & 1995 & 0.038 & 0.026 & -0.0004 & -0.035 & -0.170 & 0.101 & 0.013 \\
\hline United Kingdom & 1991 & 0.098 & 0.036 & -0.0006 & -0.157 & -0.281 & 0.196 & \\
\hline United Kingdom & 1994 & 0.111 & 0.043 & -0.0007 & -0.157 & -0.267 & 0.178 & 0.167 \\
\hline United Kingdom & 1995 & 0.101 & 0.041 & -0.0007 & -0.123 & -0.268 & 0.195 & \\
\hline United Kingdom & 1999 & 0.092 & 0.040 & -0.0007 & -0.166 & -0.204 & 0.140 & 0.145 \\
\hline United States & 1974 & 0.075 & 0.049 & -0.0008 & -0.274 & -0.389 & 0.318 & 0.047 \\
\hline United States & 1986 & 0.093 & 0.052 & -0.0009 & -0.217 & -0.338 & 0.257 & 0.054 \\
\hline United States & 1991 & 0.109 & 0.066 & -0.0011 & -0.172 & -0.380 & 0.342 & 0.047 \\
\hline United States & 1994 & 0.115 & 0.065 & -0.0011 & -0.179 & -0.321 & 0.291 & 0.041 \\
\hline United States & 1997 & 0.118 & 0.063 & -0.0011 & -0.182 & -0.296 & 0.289 & 0.037 \\
\hline United States & 2000 & 0.120 & 0.059 & -0.0010 & -0.157 & -0.318 & 0.332 & 0.041 \\
\hline
\end{tabular}

Source: Luxemboug Income Study Data

Dependent Variable: Ln Hourly wage 
Table 8: The Explanatory Power of the Human Capital Model When Taking Account of Expected Lifetime Labor Force Participation

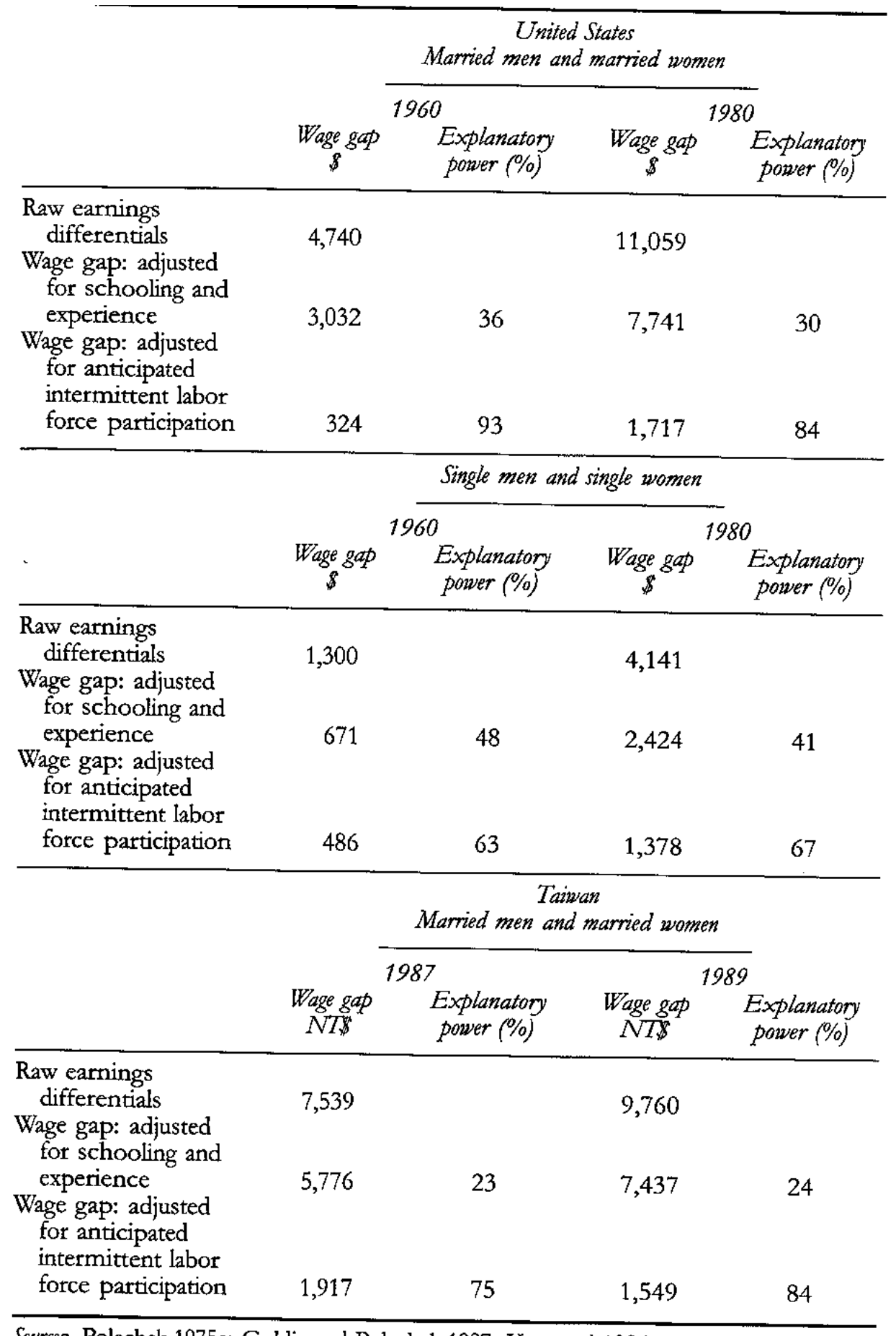

Sources. Polachek 1975a; Goldin and Polachek 1987; Kao et al. 1994 
Table 9

Estimated Atrophy Rates By Occupation (National Longitudinal Survey Of Women 30-44 Data)

\begin{tabular}{lc}
\hline Occupation & Atrophy Rate \\
\hline Professional & 45.21 \\
Managerial & 30.35 \\
Clerical & 21.64 \\
Sales & 12.61 \\
Craft & 44.68 \\
Operative & 8.17 \\
Household Work & 5.91 \\
Service & 14.87 \\
\hline
\end{tabular}

Source: Polachek (1981)

Note: Atrophy rates are computed as the decrease in earnings in cents resulting from each extra year out of the labor force. 


\section{References}

George Akerloff and Janet Yellen, eds. (1986) Efficiency Wage Models of the Labor Market, Cambridge University Press.

Randy Albelda (1986) “Occupational Segregation by Race and Gender, 1958-1981,” Industrial and Labor Relations Review, 39(3): 404-411.

J. W. Albrecht, P. A. Edin, M. Sundsstrom and S. B. Vroman (1999) Career Interruptions And Subsequent Earnings: A Reexamination Using Swedish Data, Journal of Human Resources, 34(2), 294-311.

Joseph Altonji (1993) "The Demand for and Return to Education When Education Outcomes are Uncertain," Journal of Labor Economics 11(1):48-83.

Orley Ashenfelter, William J. Collins, and Albert Yoon (2005) "Evaluating The Role Of Brown Vs. Board Of Education In School Equalization, Desegregation, And The Income Of African Americans,” NBER Working Paper 11394.

Orley Ashenfelter, Colm Harmon, and Hessel Oosterbeek, eds. (1999) Economic Returns to Schooling: New Evidence, Special Issue of Labour Economics 6(4).

Orley Ashenfelter and Alan Krueger (1994) "Estimates of the Economic Return to Schooling From A New Sample of Twins," American Economic Review, 84:1157-73.

Orley Ashenfelter and Cecilia Rouse (1998) "Income, Schooling, and Ability: Evidence From a New Sample of Identical Twins,” Quarterly Journal of Economics, 253-284.

Marjorie L. Baldwin, Lester A. Zeager and Paul R. Flacco (1994) "Gender Differences in Wage Losses from Impairments: Estimates from the Survey of Income and Program Participation," Journal of Human Resources, 29(3):865-87.

T. Barna (1947) "Review of Income From Independent Professional Practice" Economica 14(53): 64-68.

Burt Barnow, Glen Cain and Arthur Goldberger (1996) In Ashenfelter, Orley C.; LaLonde, Robert J., eds. "Issues in the Analysis of Selectivity Bias," in The economics of training. Volume 1. Theory and measurement, Elgar Reference Collection. International Library of Critical Writings in Economics, vol. 65. Cheltenham, U.K.: Elgar; distributed by Ashgate, Brookfield, Vt., pp. 182-98.

Robert Barro and Xavier Sala-i-Martin (1999) Economic Growth (Cambridge, Massachusetts: MIT Press). 
Robert Barro, Jong-Wha Lee and Nancy Stokey (1993) "Losers and Winners in Economic Growth," World Bank Research Observer, Annual Conference on Development Economics Supplement, 267-314.

Ann Bartel and Nachum Sicherman (1999) "Technological Change and Wages: An Interindustry Analysis,” Journal of Political Economy, 107(2): 285-325.

C. Baum (2002) The effect of work interruptions on women's wages, Labour 16: 1-36.

Paul Beaudry and David Green. 2000. "Cohort Patterns in Canadian Earnings: Assessing the Role of Skill Premia in Inequality Trends," Canadian Journal of Economics, 33(4): 907-36

Gary Becker 1964. Human Capital: A Theoretical and Empirical Analysis With Special Reference to Education, (New York: Columbia U Press for the NBER).

Gary Becker (1967) "Human Capital and the Personal Distribution of Income: An Analytical Approach," Woytinsky Lecture, University of Michigan; Reprinted as an Addendum to Chapter 3, in G. Becker, Human Capital, $2^{\text {nd }}$ edition, New York: Columbia University Press for the National Bureau of Economics Research, 94-144.

Gary Becker (1974) "The Theory of Marriage, Part 2," Journal of Political Economy, 82:S11-S26.

Gary S. Becker (1975) Human Capital, $2^{\text {nd }}$ ed. New York: Columbia University Press for the NBER.

G. Becker and B. Chiswick (1966) "Education and the Distribution of Earnings," American Economic Review, 56:358-69.

Gary S. Becker and Kevin M. Murphy (2007) “The Upside of Income Inequality,” The American, http://www.american.com/archive/2007/may-june-magazine-contents/theupside-of-income-inequality/.

Gary Becker and George Stigler (1974) "Law Enforcement, Malfeasance and Compensation of Enforcers," Journal of Legal Studies 3:1-18.

Efraim Benmelech and Claude Berrebi (2006). "Attack Assignments in Terror Organizations and the Productivity of Suicide Bombers”, Harvard University, Working paper.

Yoram Ben-Porath (1967) "The Production of Human Capital Over the Life Cycle," Journal of Political Economy, 75: 352-65.

Barbara Bergmann (1974) "Occupational Segregation, Wages and Profits When Employers Discriminate by Race and Sex," Eastern Economic Journal 1:103-10. 
Marianne Bertrand and Sendhil Mullainathan (2004) “Are Emily and Greg More Employable than Lakisha and Jamal? A Field Experiment on Labor Market Discrimination,” American Economic Review 94(4): 991-1013.

John H. Bishop, (1987) "The Recognition and Reward of Employee Performance," Journal of Labor Economics Supplement, 5(4):S36-56.

John H. Bishop (1988) "Match Quality, Turnover and Wage Growth," Center for Advanced Human Resource Studies, N.Y. State ILLR School Working Paper \#88-03.

Francine Blau, Marianne Ferber and Anne Winkler (2002), The Economics of Women, Men and Work, (Upper Saddle, New Jersey: Prentice Hall).

Francine Blau and Lawrence Kahn (1992) "The Gender Earnings Gap: Learning From International Comparisons," American Economic Review 82:533-8.

Alan Blinder (1973) "Wage Discrimination: Reduced Form and Structural Estimates," Journal of Human Resources, 436-55.

Alan Blinder and Yoram Weiss (1976) "Human Capital and Labor Supply: A Synthesis," Journal of Political Economy, 84:449-72.

Harold Boag (1916) "Human Capital and the Cost of War," Royal Statistical Society 717.

August Bolino (1989) A Century of Human Capital by Education and Training Washington, DC: Kensington Historical Press.

Alison Booth and Jeff Frank (1999) "Earnings, Productivity, and Performance-Related Pay,” Journal of Labor Economics, 17(3): 447-63.

John Bound and Gary Solon (1999) "Double Trouble: On the Value of Twins-Based Estimation of the Return to Schooling," Economics of Education Review, 18(2): 169-82.

George Borjas (1992) "Ethnic Capital and Intergenerational Mobility," Quarterly Journal of Economics 107(1):123-50.

George Borjas (1993) "The Intergenerational Mobility of Immigrants," Journal of Labor Economics 11(1):113-35.

John Bound and Alan Krueger (1991) "the Extent of measurement Error in Longitudinal Earnings Data: Do Two Wrongs make A Right?” Journal of Labor Economics 9(1): 1-24.

Rhead Bowman (1990) "Smith, Mill and Marshall on Human Capital Formation," History of Political Economy, 22:239-59. 
Charles Brown (1980) "Equalizing Differences in the Labor Market,” The Quarterly Journal of Economics 94(1): 113-134.

Charles Brown (1994) "Pay and Performance," Labour market and economic performance: Europe, Japan and the USA, New York: St. Martin's Press; London: Macmillan Press, pp. 216-50.

Kathy Cannings (1988) "The Earnings of Female and Male Middle Managers: A Canadian Case Study," Journal of Human Resources 23(1)35-56.

David Card (1995) "Earnings, Schooling and Ability Revisited," Research in Labor Economics 14:23-48.

David Card (1999) "The Causal Effect of Education on Earnings," on Orley Ashenfelter and David Card (eds.) Handbook of Labor Economics (Amsterdam: Elsevier Press) pp. 1801-1863.

David Card and Alan B. Krueger (1992) "School Quality and Black-White Relative Earnings: A Direct Assessment," Quarterly Journal of Economics 107(1):151-200.

David Card and Thomas Lemieux (1996) "Wage Dispersion, Returns to Skill, and BlackWhite Wage Differentials,” Journal of Econometrics, 74:319-361.

Catalyst (2003) "Workplace Flexibility Is Still A Women's Advancement Issue," http://64.233.167.104/u/Catalyst?q=cache:BGumQKH8saEJ:www.catalystwomen.org/bo okstore/files/view/Workplace\%2520Flexibility\%2520Is\%2520Still\%2520a\%2520Wome n\%27s\%2520Advancement\%2520Issue.pdf + mba + and + men + and + women\&hl=en\&ie $=\mathrm{U}$ $\underline{\mathrm{TF}-8}$

H. Lorne Charmichael (1989) "Self-Enforcing Contracts, Shirking, and Life Cycle Incentives," Journal of Economic Perspectives, 3(4):65-83.

Barry Chiswick, James Fackler, June O’Neill and Solomon Polachek (1975) "The Effect of Occupation on Race and Sex Differences in Hourly Earnings," Public Data Use 3(2): 2-9.

Barry Chiswick, Yew Liang Lee and Paul Miller (2003) "Schooling, Literacy, Numeracy and Labour Market Success,” Economic Record, 79(245): 165-81.

Barry Chiswick and Jacob Mincer (1972) "Time-Series Changes in Personal Income Inequality in the United States,” Journal of Political Economy 80(3): S34-S66.

David Clark, James Kahn and Haim Ofek (1988) "City Size, Quality of Life, and the Urbanization Deflator of the GNP: 1910-1984,” Southern Economic Journal, 54(3): 70114. 
William Cline (2001) "Trade, immigration, and Wage Distribution in Finis Welch, ed. The Causes and Consequences of Increasing Inequality (Chicago and London: The University of Chicago Press) pp. 201-239.

Amelie Constant and Douglas Massey (2003) "Self-Selection, Earnings, and OutMigration: A Longitudinal Study of Immigrants to Germany," Journal of Population Economics 16(4): 631-53.

Mary Corcoran and Greg Duncan (1979) "Work History, Labor Force Attachment, and Earnings Differences between the Races and Sexes," Journal of Human Resources, 14(1): 3-20.

Mary Corcoran, Greg Duncan, and Michael Ponza (1983) "Longitudinal Analysis of White Women's Wages,” Journal of Human Resources, 18(4): 497-520.

Council of Economic Advisors (June 1998) EXPLAINING TRENDS IN THE GENDER WAGE GAP http://clinton4.nara.gov/WH/EOP/CEA/html/gendergap.html\#13

Andrew Court (1939) "Hedonic Price Indexes with Automotive Examples," in The Dynamics of Automobile Demand (New York: General Motors Corporation) 99-117.

Louis Court (1941) "Entrepreneurial and Consumer Demand Theories for the Commodity Spectra,” Econometrica 9:135-162.

Gordon Dahl (2002) "Mobility and the Return to Education: Testing a Roy Model with Multiple Markets," Econometrica, 70(6): 2367-2420.

Beverly Dahlby and Douglas West (1986) "Price dispersion in An Automobile Insurance Market," Journal of Political Economy, 94(2):418-38.

Nasser Daneshvary,_et al. (1992) "Job Search and Immigrant Assimilation: An Earnings Frontier Approach,” Review of Economics and Statistics, 74(3): 482-92.

B. Dougherty (2003) "Why is the Rate of Return to Schooling Higher For Women Than For Men?,” Centre for Economic Performance, LSE, CEP Discussion Paper.

Jeffrey Dubin and Daniel McFadden (1984) "An Econometric Analysis of Residential Electric Appliance Holdings and Consumption," Econometrica52(2): 345-62.

Kevin Duncan and Mark Prus (1992) “Atrophy Rates for Intermittent Employment for Married and Never-Married Women: A Test of the Human Capital Theory of Occupational Sex Segregation," Quarterly Review of Economics and Finance 32(1): 2737. 
F. Y. Edgeworth (1922) “Equal Pay for Men and women,” Economic Journal 32(128): 431-457.

Isaac Ehrlich and Hiroyuki Chuma (1990) "A Model of the Demand for Longevity and the Value of Life Extension," Journal of Political Economy, 98:761-82.

Ronald Ehrenberg and M. Bognanno (1990) "Do Tournaments Have Incentive Effects?" Journal of Political Economy 98:1307-24.

Paula England (1982) "The Failure of the Human Capital Model to Explain Occupational Sex Segregation,” Journal of Human Resources 17: 358-370.

Paula England (1989) A feminist critique of rational-choice theories: implications for sociology. American Sociology, 20(1), 14-28

Evangelos Falaris (1995) "The Role of Selectivity Bias in Estimates of the Rate of Return to Schooling: The Case of Married Women in Venezuela," Economic Development and Cultural Change.

Richard Freeman (1984) "Longitudinal Analysis of the Effects of Trade Unions,"Journal of Labor Economics 2(1):1-26.

Milton Friedman and Simon Kuznets (1945) Income From Independent Professional Practice, (New York: NBER).

Victor Fuchs (1971) "Differences In Hourly Earnings Between Men And Women" Monthly Labor Review, 94(5), 9-15.

Paul Gabriel and Susanne Schmitz (2005) "A Note on Occupational Variations in the Returns to Education in the US Labor Market," International Journal of Manpower 26(5): 450-56.

Cecilia García-Peñalosa and Stephen Turnovsky (2005) "Growth and Income Inequality: A Canonical Model,” University of Washington working Paper.

Pieter Gautier and Coen Teulings (2003) "How Large are Search Frictions?” C.E.P.R. Discussion Papers, CEPR Discussion Papers: 3861.

Barry Gerhart and Nabil Cheikh (1991) "Earnings and Percentage Female: A Longitudinal Study,” Industrial Relations 30(1): 62-78.

John Gibson and Osaiasi Koliniusi Fatai (2006) "Subsidies, Selectivity and the Returns to Education in Urban Papua New Guinea," Economics of Education Review, 25(2), 133-46.

Robert Giffen (1880) Essays in Finance London: G. Bell and Sons. 
Mathew S. Goldberg and John T. Warner (1987) "Military Experience, civilian Experience, and the Earnings of Veterans, Journal of Human Resources 22(1):62-81.

Arthur Goldberger (1980) "Abnormal Selection Bias," University of Wisconsin Working Paper \#8006.

Claudia Goldin and Robert A. Margo (1992). "The Great Compression: The U.S. Wage Structure at Mid-Century," Quarterly Journal of Economics 107: 1-34.

Claudia Goldin and Solomon Polachek, (1987) "Residual Differences by Sex: Perspectives on the Gender Gap in Earnings," American Economic Review (May) 77:14351.

Leo Goodman (1960) “On the Exact Variance of a Product," Journal of the American Statistical Association 55: 708-713.

Michael Greenacre and Jörg Blasius, eds. (1994) Correspondence Analysis In The Social Sciences : Recent Developments And Applications (London ; San Diego, CA : Academic Press).

Zvi Griliches (1963) "The Sources of Measured Productivity Growth: United States Agriculture, 1940-60," Journal of Political Economy 71:331-46;

Zvi Griliches (1964) "Research Expenditures, Education, and the Aggregate Aggricultureal Production Function," American Economic Review 54(6):961-74.

Zvi Griliches and Jerry Hausman (1986) "Errors in Variables in Panel DataFind More Like This,” Journal of Econometrics 31(1): 93-118.

Reuben Gronau (1974) "Wage Comparison -- A Selectivity Bias,"Journal of Political Economy 82(6):119-43.

Reuben Gronau (1988) "Sex-Related Wage Differentials and Women's Interrupted Labor Careers--The Chicken or the Egg,” Journal of Labor Economics, 6(3): 277-301.

Wim Groot and Hessel Oosterbeek (1994) "Stochastic Reservation and Offer Wages," Labour Economics 1(3/4):383-90.

David Grusky and Charles, Maria (1998) “The Past, Present, and Future of Sex Segregation Methodology,” Demography 35(4): 497-504.

Yves Guyot (1914) "The Waste of War and the Trade of Tomorrow," Nineteenth Century and After 76:1193-1206.

Eric Hanushek (1996) "Measuring Investment in Education," Journal of Economic Perspectives, 10(4): 9-30. 
Eric Hanushek, James Heckman and Derek Neal (2002) "Introduction to the Journal of Humen Resources Special Issue on Designing Incentives to Promote Human Capital,” Journal of Human Resources, 37(4): 693-95.

Eric Hanushek, John Kain, and Steven Rivkin (2002) "Inferring Program Effects for Special Populations: Does Special Education Raise Achievement for Students with Disabilities?” Review of Economics and Statistics, 84(4): 584-99.

John Hanson (1989) "Education, Economic Development, and Technology Transfer: A Colonial Test," Journal of Economic History 49:393-57.

Susan Harkness and Jane Waldfogel (2003) “The Family Gap in Pay: Evidence from Seven Industrialized Countries," in S. Polachek (ed.) Worker Well-Being and Public Policy, Research in Labor Economics 22: 369-413.

Joop Hartog, Gerald Pfann and Geert Ridder (1989) "(Non-)graduation and the Earnings Function: An Inquiry on Self-Selection,” European Economic Review 33(7): 1373-95 .

Masanori Hashimoto (1975) "Wage Reduction, Unemployment and Specific Human Capital," Economic Inquiry 13(4):485-504.

James Heckman (1976) “A Life-Cycle Model of Earnings, Learning, and Consumption,” Journal of Political Economy, 84(4): S11-44.

James Heckman (1979) "Sample Selection Bias as a Specification Error," Econometrica 47:153-61.

James Heckman (1998) “Detecting Discrimination,” Journal of Economic Perspectives, 12(2): 101-16.

James Heckman, Lance Lochner, and Petra Todd (2003) "Fifty Years of Mincer Earnings Regressions,” National Bureau of Economic Research Working Paper No. 9732.

James Heckman and Solomon Polachek (1974) "The Functional Form of the IncomeSchooling Relation," Journal of the American Statistical Association 69:350-54.

James Heckman and Richard Robb (1985) "Using Longitudinal Data to Estimate Age, Period and Cohort Effects in Earnings Equations," in Analyzing Data for Age, Period and Cohort Effects, S. Feinberg and W. Mason eds, (New York: Academic Press).

James Heckman and Peter Siegelman (1993) "The Urban Institute Audit Studies: Their Methods and Findings," in Clear and convincing evidence: Measurement of discrimination in America, (Washington, D.C.: Urban Institute Press), pp. 187-258. 
Joni Hirsch (2006) "Sex Discrimination in the Labor Market," 2(4) Foundations and Trends in Microeconomics 2(4): 281-361.

Richard Hofler and Kevin Murphy (1992) "Underpaid and Overworked: Measuring the Effect of Imperfect Information on Wages,” Economic Inquiry, 30(3): 511-29

Richard Hofler and Solomon Polachek (1982) "Ignorance in the Labor Market: A New Approach for Measuring Information in the Labor Market," Proceedings of the American Statistical Association, 422-5.

Julie Hotchkiss and Melinda Pitts (2003) At what level of labour market intermittency are women penalized?, American Economic Review Papers and Proceedings 93: 233-7.

Julie Hotchkiss and Melinda Pitts (2005) "Female Labour Force Intermittency and Current Earnings: Switching Regression Model with Unknown Sample Selection," Applied Economics 37(5): 545-60 .

Hendrik Houthakker, (1951-52) "Compensated Changes in Quantities and Qualities Consumed,” Review of Economic Studies 19: 155-164.

Charles R. Hull, ed. 1899. The Economic Writings of Sir William Petty, (Cambridge: The University Press).

Thomas Hungerford and Gary Solon (1987) "Sheepskin Effects In The Returns To Education,” Review of Economics \& Statistics, 69(1): 175-177.

Robert Hutchens (1989) "Seniority, Wages and Productivity: A Turbulent Decade," Journal of Economic Perspectives, 3(4):49-64.

Soo Kyeong Hwang and Solomon W. Polachek (2005) "Occupational Self-Selection and the Gender Wage Gap: Evidence From Korea and United States,” Working Paper.

Susumu Imai and Michael Keane (2004) "Intertemporal Labor Supply and Human Capital Accumulation,” International Economic Review, 45(2):601-641.

J. P. Jacobsen and L. M. Levin (1995) Effects Of Intermittent Labour Force Attachment On Women’s Earnings,” Monthly Labour Review, September, 14-19.

D. A. Jaeger and M. E. Page (1996) Degrees Matter: New Evidence On Sheepskin Effects In The Returns To Education,” Review of Economics and Statistics, 78, 733-40.

Harish Jain, Peter Sloane, and Frank Horwitz (2003) Employment Equity and Affirmative Action: An International Comparison (New York and London: M. E. Sharpe).

Feng-Fuh Jiang and Solomon Polachek (1991) "Investment Dependent Labor Supply," Research in Labor Economics 12:245-67. 
D. Gale Johnson (1954) "The Functional Distribution of Income in the United States, 1850-1952,” The Review of Economics and Statistics, 36(2): 175-182.

George Johnson and Gary Solon (1986), "Estimation of the Direct and Indirect Costs of Comparable Worth,” American Economic Review, 76:1117-25.

Thomas Johnson (1970) "Returns From Investments in Human Capital," American Economic Review, 60:546-60.

Thomas Johnson (1978) "Time in School: The Case of the Prudent Patron," American Economic Review, 862-72.

Alison Snow Jones and David Richmond (2006) "Causal Effects of Alcoholism on Earnings: Estimates from the NLSY,” Health Economics 15(8): 849-71.

Boyan Jovanovic (1979a) "Firm-Specific Capital and Turnover," Journal of Political Economy, 87(6):1246-1260.

Boyan Jovanovic (1979b) "Job Matching and the Theory of Turnover," Journal of Political Economy, 87(5):972-90.

Richard Kamalich and Solomon Polachek (1982) "Discrimination: Fact or Fiction? An Examination Using an Alternative Approach,” Southern Economic Journal 49(2): 45061.

Charng Kao, Solomon Polachek and Phanindra Wunnava (1994) "Male-Female Wage Differentials in Taiwan: A Human Capital Approach," Economic Development and Cultural Change, 42(2):351-74.

Friedrich Kapp (1870) Immigration and the Commissioners of the State of New York, New York: E. Steigen and Company.

B. F. Kiker (1966) "The Historical Roots and the Concept of Human Capital," Journal of Political Economy, 74:481-799.

B. F. Kiker, (1971) Investment in Human Capital, Columbia: South Carolina.

B. F. Kiker and M. Mendes de Oliveira (1992) "Optimal Allocation of Time and Estimationb of Market Wage Functions," Journal of Human Resources 27(3):445-71.

Moon-Kak Kim and Solomon Polachek (1994) "Panel Estimates of Male-Female Earnings Functions,” Journal of Human Resources 29(2):406-428.

Mary King (1992) “Occupational segregation by race and sex,” Monthly Labor Review 115(4): 30-37. 
Thomas Kniesner and John Leeth (1991) “Compensating Wage Differentials for Fatal Injury Risk in Australia, Japan, and the United States,” Journal of Risk and Uncertainty 4(1): 75-90

Thomas Kniesner, Arthur Padilla, and Solomon Polachek (1978) "The Rate of Return to Schooling and the Business Cycle,” Journal of Human Resources 13(2): 264-277.

Thomas Kniesner, Arthur Padilla, and Solomon Polachek (1980) “The Rate of Return to Schooling and the Business Cycle: Additional Estimates," Journal of Human resources 15(2): 273-277.

Thomas KniesnerW. Kip Viscusi (1995) "Value of a Statistical Life: Relative Position vs. Relative Age,” American Economic Review 95(2): 142-46

Thomas Kniesner, W. Kip Viscusi, Christopher Woock, and James Ziliak (2006) "Pinning Down the Value of Statistical Life ," Center for Policy Research, Maxwell School, Syracuse University, Center for Policy Research Working Papers \#85.

Marvin Kosters (2001) "Government Policy and wage Inequality: Regulation, Incentives, and Opportunities," in Finis Welch, ed. The Causes and Consequences of Increasing Inequality (Chicago and London: The University of Chicago Press) pp. 201-239.

Alan B. Krueger (1999) “Measuring Labor's Share,” Papers and Proceedings of the One Hundred Eleventh Annual Meeting of the American Economic Association, 45-51.

Subal Kumbhakar (1996) "A Farm-Level Study of Labor Use and Efficiency Wages in Indian Agriculture,” Journal of Econometrics, 72:177-95.

M. Kuratani (1973) "A Theory of Training, Earnings and Employment in Japan," Ph.D. Dissertation, Columbia University.

Simon Kuznets (1961) Capital in the American Economy: Its Formation and Financing, Princeton for the NBER.

Saul Lach and Daniel Tsiddon (1992) "The Behavior of Prices and Information: An Empirical Analysis of Disaggregated Price Data," Journal of Political Economy 100:34989.

Edward Lazear (1979) "Why Is There Mandatory Retirement?" Journal of Political Economy, 87:1261-84.

Edward Lazear (1981) "Agency Earnings Profiles, Productivity, and Hours Restrictions," American Economic Review 71:606-20. 
Edward Lazear and Sherwin Rosen (1981) "Rank-Order Tournaments as Optimum Labor Contracts," Journal of Political Economy, 89:841-64.

L-F Lee (1983) "Generalized Econometric Models with Selectivity," Econometrica, 51: 507-512.

L-F Lee (1982) "Some Approaches to the Correction of Selectivity Bias," Review of Economic Studies 49: 355-372.

Thomas Lemieux (2006) "The "Mincer Equation" Thirty Years after Schooling, Experience, and Earnings," in Jacob Mincer : A Pioneer Of Modern Labor Economics, Shoshana Grossbard, ed. (New York, NY : Springer Science).

Thomas Lemieux (2006) "Increasing Residual Wage Inequality: Composition Effects, Noisy Data, or Rising Demand for Skill?” American Economic Review, 96(3): 461-98.

Thomas Lemieux, W. Bentley Macleod and Daniel Parent (2006) "Performance Pay and Wage Inequality,” working paper.

W. Leontief (1946) "Exports, Imports, Domestic Output and Employment," Quarterly Journal of Economics.

David Levhari and Yoram Weiss (1974) "The Effect of Risk on the Investment in Human Capital,” American Economic Review, 64(6): 950-63.

H. Gregg Lewis (1986), Union relative wage effects : a survey, Chicago : University of Chicago Press.

G. Licht and V. Steiner (1991) "Male-Female Wage Differentials, Labor Force Attachement, and Human Capital Accumulation in Germany," Working Paper No. 65 (institut fr Volkswirtschafslehre der Universit Augburf).

Audrey Light and Manuelita Ureta (1995) "Early-Career Work Experience and Gender Wage Differentials,” Journal of Labor Economics 13(1): 121-154.

Lee A. Lillard (1977) "Inequality: Earnings Versus Human Wealth," American Economic Review, 67:45-53.

R. J. A. Little (1982) "Models for Nonresponse in Sample Surveys," Journal of the American Statistical Association 77: 237-250.

Roderick Little (1985) “A Note About Models for Selectivity Bias,” Econometrica, 53(6): 1469-1474.

Lance Lochner (2004) "Find More Like ThisEducation, Work, and Crime: A Human Capital Approach,” International Economic Review, 45(3): 811-43 . 
Lance Lochner and Enrico Moretti (2004) "The Effect of Education on Crime: Evidence from Prison Inmates, Arrests, and Self-Reports,” American Economic Review, 94(1): 155-89.

D. Macpherson and B. Hirsch (1995) "Wages And Gender Composition: Why Do Women's Jobs Pay Less?” Journal of Labor Economics, 13(3): 426-471.

James Medoff and Katherine Abraham (1980) "Experience, Performance and Earnings," Quarterly Journal of Economics 95:703-36.

Jennifer Mellor and Elizabeth Paulin (1995) "The Effects of Gender and Race on Salary Growth: The Role of Occupational Structure in a Service Sector Firm” Eastern Economic Journal, 21(3): 375-92.

Robert T. Michael. 1973. "Education in Nonmarket Production," Journal of Political Economy, 81(2): 306-27.

Carloe Miller (1993), “Actual Experience, Potential Experience or Age, and Labor Force Participation by Married Women,” Atlantic Economic Journal 21(4):60-66.

Jacob Mincer (1958) "Investment In Human Capital and the Personal Income Distribution," Journal of Political Economy, 66:281-302.

Jacob Mincer (1974) Schooling, Experience, and Earnings, (New York: Columbia University Press for the National Bureau of Economic Research).

J. Mincer (1970) "The Distribution of Labor Incomes: A Survey," Journal of Economic Literature, 8(1): 1-26.

Jacob Mincer (1978) "Family Migration Decisions," Journal of Political Economy 74973.

Jacob Mincer (1993) "Human Capital, Technology, and the Wage Structure: What Do Time Series Show?" in J. Mincer, ed. Studies in Human Capital (Brookfield, VT: E. Elgar Publishing).

Jacob Mincer (1997) “Changes in Wage Inequality, 1970-1990,” in Research in Labor Economics 16:1-18.

Jacob Mincer (1993) "Job Training: Costs, Returns, and Wage Profiles," in J. Mincer, Studies in Human Capital, 1993, (Edward Elgar) Chapter 9: 263-281.)

Jacob Mincer and Boyan Jovanovic (1981) "Labor mobility and wages," in Studies in Labor markets, Sherwin rosen, ed. (Chicago: Univeristy of Chicago Press), pp 21-64. 
Jacob Mincer and Haim Ofek (1982) "Interrupted Work Careers: Depreciation and Restoration of Human Capital," Journal of Human Resources, 17:3-24.

Jacob Mincer and Solomon Polachek (1974) "Family Investments in Human Capital," Journal of Political Economy 82:S76-108.

Jacob Mincer and Solomon Polachek (1978) “Women's Earnings Reexamined,” Journal of Human Resources, 13(1): 118-34.

Leonor Modesto (2003) "Should I Stay or Should I Go? Educational Choices and Earnings: An Empirical Study for Portugal," Journal of Population Economics 16(2): 307-22.

Kevin Murphy and Robert Topel (1990) "Efficiency Wages Reconsidered: Theory and Evidence," in Advances in the Theory and Measurement of Unemployment (Yoram Weiss and Gideon Fishelson, eds.), New York: St. Martins Press, 204-44.

Kevin Murphy and Finis Welch (1990) "Empirical Age-Earnings Profiles," Journal of Labor Economics 8:202-29.

Ruth-Aïda Nahum (2005) "Income Inequality and Growth: a Panel Study of Swedish Counties 1960-2000,” Institute for Futures Studies, working Paper 2005:3.

Phillip Nelson (1970) “Information and Consumer Behavior," Journal of Political Economy 78(2): 311-329.

Phillip Nelson and Solomon Polachek (1995) "Discerning Discrimination: Does Interviewing Firms Make a Difference?” Eastern Economic Journal 21(3): 393-399.

Neumark, David (1996) "Sex Discrimination in Restaurant Hiring: An Audit Study," Quarterly Journal of Economics, 111(3): 915-41.

Ronald Oaxaca (1973) “Male-Female Wage Differentials in Urban Labor Markets," International Economic Review, 14(3): 693-709).

Walter Oi, (1962) "LAbor as a Quasi-Fixed Factor," Journal of Political Economy, 70:538-55.

R. J. Olsen (1980) "A Least Squares Correction for Selectivity Bias," Econometrica 48:1815-1820.

R. J. Olsen (1982) "Distributional Tests for Selectivity Bias and a More Robust Likelihood Estimator," International Economic Review 23: 223-240. 
Peter Orazem and Peter Mattila (1991) "Human Capital, Uncertain Wage distributions, and Occupational and Educational Choices," International Economic Review, 32(1):10322.

M. Paglin and A. Rufolo (1990) "Heterogeneous Human Capital: Occupational Choice and Male-Female Earnings Differences," Journal of Labor Economics 8:123-44.

Daniel Parent (2002) "Matching, Human Capital, and the Covariance Structure of Earnings,” Labour Economics, 9(3): 375-404.

Donald Parsons (1977) "Models of Labor Market Turnover: A Theoretical and Empirical Survey," Research in Labor Economics,1:185-223.

John Pencavel (1972) "Wages, Specific Training, and Labor Turnover in U.S. Manufacturing," International Economic Review, 13(1):53-64.

S. Phipps, P. Burton, and L. Lethbridge (2001) In and out of the labour market: longterm income consequences of child-related interruptions to women's paid work, Canadian Journal of Economics, 34(2): 411-29.

Arthur Cecil Pigou (1928), A Study in Public Finance, London: Macmillan.

Thomas Piketty and Emmanuel Saez (2003) "Income Inequality In The United States, 1913-1998,” Quarterly Journal Of Economics 118(1): 1-39.

Dora Polachek and Solomon Polachek (1989) “An Indirect Test of Children's Influence on Efficiencies in Parental Consumer Behavior,” Journal of Consumer Affairs, 23(1): 91110.

Solomon Polachek (1975a), "Differences in Expected Post-School Investment as a Determinant of Market Wage Differentials," International Economic Review 16:451-70.

Solomon Polachek (1975b) "Potential Biases in Measuring Discrimination," Journal of Human Resources 6:205-29.

Solomon Polachek (1976) "Occupational Segregation: An Alternative Hypothesis," Journal of Contemporary Business 5:1-12.

Solomon Polachek (1978) "Sex Differences in College Major," Industrial and Labor Relations Review 31(4):498-508.

Solomon Polachek (1979) "Occupational Segregation Among Women: Theory, Evidence, and A Prognosis," in Lloyd, Andrews and Gilroy (eds.) Women in the Labor Market, (New York: Columbia University Press), 137-57. 
Solomon Polachek (1981) "Occupational Self-Selection: A Human Capital Approach to Sex Differences in Occupational Structure," Review of Economics and Statistics, 63(1):60-69.

Solomon Polachek (1985) "Occupational Segregation: A Defense of Human Capital Predictions," Journal of Human Resources 20(3): 437-440.

Solomon Polachek (1995) "Earnings Over the Life Cycle: What Do Human Capital Models Explain?" Scottish Economic Journal, 42 (3): 267-289.

Solomon Polachek (2003) "Mincer's Overtaking Point and the Life Cycle Earnings Distribution," Review of Economics of the Household, 1: 273-304.

Solomon Polachek (2006) "How the Life-Cycle Human Capital Model Explains Why the Gender Wage Gap Narrowed," in the Declining Significance of Gender (F. Blau, M. Brinton, and D. Grusky, eds.), New York: Russell Sage Foundation pp. 102-124.

Solomon Polachek and Francis Horvath (1977) "A Life Cycle Approach to Migration: Analysis of the Perspicacious Peregrinator," Research in Labor Economics 1:103-49.

Solomon Polachek and Moon-Kak Kim (1994) "Panel Estimates of the Gender Earnings Gap: Individual Specific Intercept and Individual Specific Slope models," Journal of Econometrics 61(1):23-42.

Solomon Polachek and Ernst McCutcheon (1983) "Union Effects on employment Stability: New Estimates Using Panel Data,” Journal of Labor Research 4: 273-287.

Solomon Polachek and John Robst (1998) "Employee Labor Market Information: Comparing Direct World of Work Measures of Workers' Knowledge to Stochastic Frontier Estimates,” Labour Economics, 5(2): 231-42.

Solomon Polachek and John Robst (2001) "Trends in the Male-Female Wage Gap: The 1980s Compared with the 1970s” Southern Economic Journal, 67(4): 869-88.

Solomon Polachek and W. Stanley Siebert (1993) The Economics of Earnings (Cambridge and New York: Cambridge University Press).

Solomon Polachek, Phanindra Wunnava and Michael Hutchins (1987) Panel Estimates of Union Effrects on Wages and Wage Growth," Review of Economics and Statistic 69(3): 527-531.

Solomon Polachek and Jun (Jeff) Xiang (2006) "The Effects of Incomplete Employee Wage Information: A Cross-Country Analysis," in The Economics of Immigration and Social Diversity, Research in Labor Economics (Amsterdam and San Diego: Elsevier) pp. 35-75. 
Solomon Polachek and Bong Yoon (1987) "A Two-Tiered Earnings Frontier: Estimation of Employer and Employee Information in the Labor Market," Review of Economics and Statistics 69:296-302.

Solomon Polachek and Bong Yoon (1996) "Panel Estimates of A Two-Tiered Earnings Frontier," Journal of Applied Econometrics 11 (2): 169-178.

G. Psacharopoulos (1985) "Returns to Education: A Further International Update and Implications," Journal of Human Resources,20:583-604.

George Psacharopoulos and Harry Anthony Patrinos (2004), "Returns to Investment in Education: A Further Update,” Education Economics, 12(2): 111-34 .

Eleanor F. Rathbone (1917) “The Remuneration of Women's Services,” The Economic Journal 27(105): 55-68.

Albert Rees, (1966) "Information Networks in the Labor Market," American Economic Review 56:559-66.

Sherwin Rosen, (1972) "Learning and Experience in the Labor Market," Journal of Human Resources 7(3):326-42.

Sherwin Rosen, (1974) "Hedonic Prices and Implicit Markets: Product Differentiation in Pure Competition," Journal of Political Economy,82:34-55.

Sherwin Rosen (1986) "Prizes and Incentives in Elimination Tournaments," American Economic Review 76:701-15.

Erin Ruel (2004) “Trends in Occupational Sex and Race segregation from 1940-2000," Paper presented at the annual meeting of the American Sociological Association, San Francisco, CA.

S. Rummery (1992) The contribution of intermittent labour force participation to the gender wage differential, Economic Record 68(203): 351-64.

H. Ryder, F. Stafford and P. Stephan (1976) "Labor, Leisure, and Training Over the Life Cycle," International Economic Review 17:651-74.

Steven Sandell and David Shapiro (1980) "Work Expectations, Human Capital Accumulation and the Wages of Young Women," Journal of Human Resources 335-53.

Bisakha Sen (2001) "Revisiting Women's Preferences about Future Labor Force Attachment: What Effects Do They Have on Earnings and What Are They Affected By? in Worker wellbeing in a changing labor market, Reseaerch in Labor Economics, pp. 311-37. 
T. W. Schultz (1961) "Education and Economic Growth," in Social Forces Influencing American Education, $60^{\text {th }}$ Yearbook of the National Society for the Study of Education, Chicago, Ch. 3.

T. W. Schultz (1961) "Investment in Human Capital", American Economic Review, 51(1): 1-17.

T. W. Schultz (1963) The Economic Value Of Education. New York: Columbia University Press.

Carl Shapiro and Joseph Stiglitz (1984) "Equilibrium Unemployment as a Worker Discipline Device," American Economic Review 433-44.

Kathryn Shaw (1989) "Life-Cycle Labor Supply With Human Capital Accumulation," International Economic Review, 89(30): 431-456.

Eytan Sheshinski (1968) "On the Individual's Lifetime Allocation Between Education and Work," Metroeconomics, 20:42-40.

Wayne Simpson (2000) "Intermittent Work Activities and Earnings," Applied Economics, 32(14): 1777-86.

Adam Smith $(1776,1966)$ An inquiry into the nature and causes of the wealth of nations (London: Printed for W. Strahan and T. Cadell, 1776. (New York, : A. M. Kelley, 1966).

James Smith and Finis Welch (1984) "Affirmative Action and the Labor Market," Journal of Labor Economics, 2:269-98.

Arthur Snow and Ronald Warren (1990) "Human Capital Investment and Labor Supply Under Uncertainty," International Economic Review, 31(1): 195-206.

Alan Sorensen (2000) "Equilibrium Price Dispersion in Retail Markets for Prescription Drugs,” Journal of Political Economy 108(4): 833-850.

Elaine Sorenson (1990) "The Crowding Hypothesis And Comparable Worth Issue," Journal of Human Resources, 25(1), 55-89.

Elaine Sorensen (1993) "Continuous Female Workers: How Different Are They from Other Women?” Eastern Economic Journal 19(1): 15-32.

Michael Spence (1973) "Job Market Signalling," Quarterly Journal of Economics 87: 355-74.

Frank Stafford and Marianne Sundstrom (1996) "Time Out for Childcare: Signalling and Earnings Rebound Effects for Men and Women,” Labour, 10(3): 609-29. 
George Stigler (1961) "The Economics of Information," Journal of Political Economy 69:213-25.

George Stigler and James Kindahl (1970) The Behavior of Industrial Prices New York: Columbia University Press.

L. Stratton (1995) The Effect Of Interruptions In Work Experience Have On Wages, Southern Economic Journal 61(4): 955-70.

Donald Street (1988), "Jovellanos, An Antecedent to Modern Human Capital Theory", History of Political Economy, 20:191-206.

Paul Taubman (1976) "The Determinants of Earnings: Genetics, Family and Other Environments," American Economic Review 66:858-70.

Paul Taubman (1976) "Earnings, Education, Genetics and Environment," Journal of Human Resources 11(4): 447-461.

Richard Thaler and Sherwin Rosen (1976) "The Value of Saving A Life: Evidence From the Labor Market," in Household Production and consumption, Nestor Teleckyj, ed. (New York: Columbia University Press) pp. 265-298.

Jan Tinbergen (1951) "Some Remarks on the Distribution of LAbour Incomes," International Economic Papers 195-207.

Donald Treiman and Heidi Hartmann, eds. (1981) Women, Work and Wages: Equal Pay for Jobs of Equal Value (Washington, DC: National Academy Press).

Philip Trostel, Ian Walker, and Paul Woolley (2002), "Estimates of the Economic Return to Schooling for 28 Countries," Labour Economics, 9(1): 1-16.

Lester Thurow (1969) “Poverty And Discrimination,” Washington, Brookings Institution.

Theresa Van Hoomissen (1988) "Price Dispersion and Inflation: Evidence From Israel," Journal of Political Economy, 96:1303-14.

W. Kip Viscusi, (1979) "Job Hazards and worker Quit Rates," International Economic Review, 20:29-58.

John Walsh (1935) "Capital Concept Applied to Man," Quarterly Journal of Economics 49:255-85.

T. Dudley Wallace and Lauren Ihnen (1975) "Full-time Schooling in Life Cycle Models of Human Capital Accumulation," Journal of Political Economy, 83(1):137-55. 
Doris Weichselbaumer and Rudolf Winter-Ebmer (2003) "The Effects of Markets, Politics, and Society on the Gender Wage Differential: A Meta-Analysis” Department of Economics, Johannes Kepler University of Linz Working Paper No. 0311.

Yoram Weiss and Reuben Gronau (1981) "Expected Interruptions in Labor Force Participation and Sex Related Differences in Earnings Growth, Review of Economic Studies 48(4):607-19.

Finis Welch (1974) "Black White Differences in Returns to Schooling," American Economic Review, 63(5):893-907.

Robert Willis and Sherwin Rosen (1979) "Education and Self-Selection," Journal of Political Economy, 87(5): S7-36.

C. R. Winegarden (1979) "Schooling and Income Distribution: Evidence from International Data,” Economica 46(181): 83-87.

James Ziliak (2005) "Understanding Poverty Rates and Gaps: Concepts, Trends and Challenges," Foundations and Trends in Microeconomics 1(3): 1-75. 